\title{
FROM CONFLICTING TO COMPLEMENTING: \\ THE FormalisATION OF CUSTOMARY LAND MANAGEMENT SYSTEMS GOVERNING SWIDDEN CULTIVATION IN MYANMAR
}

BY

\section{JIM DAVID ENNION}

A thesis submitted to the Victoria University of Wellington in fulfilment of the requirements for the degree of Master of Laws

TE WHARE WĀNANGA O TE ŨPOKO O TE IKA A MĀUI

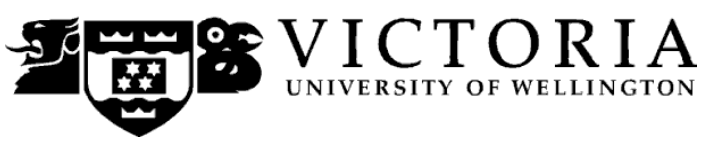

2015 


\section{Abstract}

Swiddening is a traditional and widespread agricultural system in mountainous regions of Southeast Asia. It is prevalent in Myanmar's hilly border region. However, economic, political, demographic, social and technological drivers in this region are causing this form of land use to undergo significant transition. This transition is affecting the customary land use rights of swidden farmers.

Throughout Myanmar's tumultuous history, customary land management systems and the state land management system have been poorly integrated. This has led to customary land use rights receiving little formal recognition and left customary right-holders vulnerable to exploitation.

Recent political and economic developments within Myanmar have prompted changes to the state land management system. The Myanmar government introduced the Farmland Law 2012 and the Vacant Fallow and Virgin Lands Management Law 2012 which significantly altered how agricultural land is managed. However, these laws also contain minimal interaction with customary land management systems. In relation to swidden cultivation, the legislation is unclear how land under customary tenure is identified, how communally-held land is recognised and what swidden practices are legally permitted.

The draft National Land Use Policy released in late 2014 reveals progress in addressing these issues. However, greater clarity is needed with regard to how the policy is implemented. Many lessons may also be derived from the experiences of surrounding Southeast Asian countries, such as the Philippines and Cambodia, in the way customary land use rights are incorporated into state legislation.

The goal of this thesis is to propose how customary land management systems may be integrated into the state land management system in order for customary land use rights over swidden land to be recognised as comprehensively as possible by the state. The legislative framework should also allow sufficient flexibility for local farmers to adapt to changing circumstances. The identification of swidden land will be considered in the context of producing maps of customary land use, the management of swidden land under collective landholding structures will be discussed with regard to pressures to individualise land-holding and the use of swidden cultivation practices will be considered in light of proposed development projects.

The current political and economic climate in Myanmar indicates some willingness to acknowledge and address these issues. There is hope that customary land management systems and the state land management system will begin to complement, instead of conflict with, each other in order to enable swidden farmers to access their customarily held land into the future.

\section{Subjects and Topics}

Formalisation, Customary land tenure, Swidden, Myanmar, Southeast Asia, 


\section{Table of Contents}

Acknowledgements and abbreviations ............................................................. iv

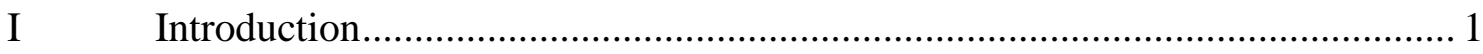

II Theoretical framework..................................................................... 8

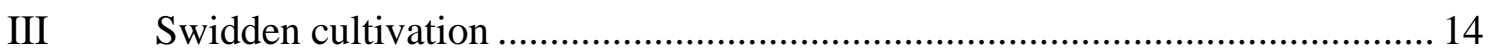

IV Customary Land Management (CLM) systems ....................................... 25

$\mathrm{V} \quad$ The State Land Management (SLM) system in Myanmar .............................. 31

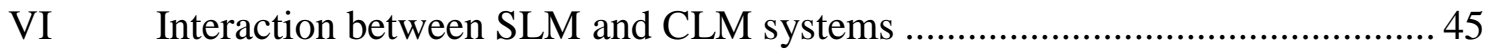

VII 2012 Land Law Reforms ..................................................................... 58

VIII Interaction between CLM systems and the Farmland Law and VFV Law ...... 64

IX Formalisation of customary land use rights ........................................... 79

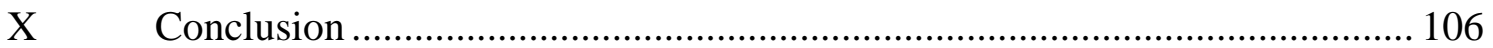

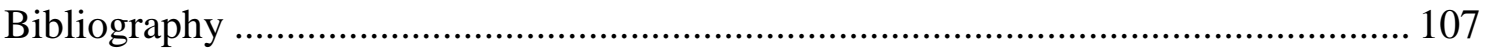




\section{Acknowledgements}

This thesis would not have been possible without the support of many people. I would like to thank my supervisors at Victoria University of Wellington. You have helped and guided me through this thesis. Thanks also to Anton and Wendy. Without your support for our family, this year would not have been possible. Thank you Mum and Dad Mcmillan for giving so much of your time to us. Thank you to my beautiful children, your smiles always bring me joy. And most of all, thank you to Nitika, my incredible wife, you have been a rock of support and encouragement throughout this year.

\section{Abbreviations}

BSPP

CBNRM

Central Committee

CCML

CFI

CLM

FIC

FPIC

GIS

MoAI

MoECAF

NCIP

NLUP

P3DM

PLUP

SAC

SLM

SLORC

USDP

VFV

VFV Law

Wasteland Law

Wasteland Procedures
Burma Socialist Programme Party

Community-Based National Resource Management

Central Committee for the Management of Culturable Land, Fallow Land and Waste Land

Central Committee for the Management of Vacant, Fallow and Virgin Lands

Community Forestry Instructions 1995

Customary Land Management

Foreign Investment Commission

Free and prior informed consent

Geographic Information Systems

Ministry of Agriculture and Irrigation

Ministry of Environmental Conservation and Forestry

National Commission on Indigenous Peoples

National Land Use Policy

Participatory 3 Dimensional Mapping

Participatory land-use planning

Security and Administrative Committee

State Land Management

State Law and Order Restoration Council

Union Solidarity and Development Party

Vacant, Fallow and Virgin

Vacant, Fallow and Virgin Lands Management Law 2012

Duties and Rights of the Central Committee for the Management of Culturable Land, Fallow Land and Waste Land 1991

Procedures Conferring the Right to Cultivate Land/Right to Utilize Land 1991 


\section{Abundant food is in the fallow ground of the poor, But it is swept away by injustice.}

Proverbs 13:23

\section{Introduction}

Swiddening is a traditional and well-established agricultural system in Myanmar. It provides subsistence or supplementary livelihood to many farming families, particularly in Myanmar's hilly border regions. ${ }^{1}$ However, it continues to come under pressure from economic, political, demographic, social and technological changes facing the whole of Southeast Asia. ${ }^{2}$ These drivers are causing a transition from widespread reliance on swidden to more permanent forms of cultivation. ${ }^{3}$ Although, given the persistence of swidden cultivation, this transition may extend well into the $21^{\text {st }}$ Century. ${ }^{4}$

It is important to protect swidden farmers' customary land use rights during this

\footnotetext{
${ }^{1}$ Hla Tun Aung Myanmar: The Study of Processes and Patterns (National Centre for Human Resource Development, Publishing Committee, Ministry of Education, Myanmar, 2003) at 144; K Eberhardt "A review of challenges to sustainable development in the uplands of Myanmar" in Landscapes of Diversity: Indigenous Knowledge, Sustainable Livelihood and Resource Governance in Montane Mainland Southeast Asia Proceedings of the III Symposium on MMSEA 25-28 August 2002, Lijiang, PR China (2003) 101; Dietrich Schmidt-Vogt and others "An Assessment of Trends in the Extent of Swidden in Southeast Asia" (2009) 37 Human Ecology 269 at 272.
}

2 RA Cramb and others "Swidden Transformations and Rural Livelihoods in Southeast Asia" (2009) 37 Human Ecology 323; Jefferson Fox and others "Policies, Political-Economy, and Swidden in Southeast Asia" (2009) 37 Human Ecology 305; Peng Li and others "A Review of Swidden Agriculture in Southeast Asia" (2014) 6 Remote Sensing 1654; Ole Mertz and others "Who Counts? Demography of Swidden Cultivators in Southeast Asia" (2009) 37 Human Ecology 281; Schmidt-Vogt and others, above n 1; Nathalie Van Vliet and others "Trends, drivers and impacts of changes in swidden cultivation in tropical forest-agriculture frontiers: A global assessment" (2012) 22 Global Environmental Change 418; N Van Vliet and others "Is There a Continuing Rationale for Swidden Cultivation in the 21st Century?" (2013) 41 Human Ecology 1; AD Ziegler, JM Fox and J Xu "The Rubber Juggernaut" (2009) 324 Science 1024; Roy Ellen "Studies of Swidden Agriculture in Southeast Asia since 1960: An Overview and Commentary on Recent Research and Syntheses" (2012) 3 Asia Pacific World 18 at 26.

${ }^{3} \mathrm{Li}$ and others, above n 2, at 1672; Jefferson Fox and Jean-Christophe Castella "Expansion of rubber (Hevea brasiliensis) in Mainland Southeast Asia: what are the prospects for smallholders?" (2013) 40 Journal of Peasant Studies 155; Xiaona Liu and others "Rubber plantation and its relationship with topographical factors in the border region of China, Laos and Myanmar" (2013) 23 J Geogr Sci 1019; Zhe Li and Jefferson Fox "Mapping rubber tree growth in mainland Southeast Asia using time-series MODIS $250 \mathrm{~m}$ NDVI and statistical data" (2012) 32 Applied Geography 420; Jianchu Xu, R Edward Grumbine and Philip Beckschäfer "Landscape transformation through the use of ecological and socioeconomic indicators in Xishuangbanna, Southwest China, Mekong Region" (2014) 36 Ecological Indicators 749; Ziegler, Fox and Xu, above n 2; Kevin Woods "Community Forestry in Cease-Fire Zones in Kachin State, Northern Burma: Formalizing Collective Property in Contested Ethnic Areas" (paper presented to CAPRi Workshop on Collective Action, Property Rights, and Conflict in Natural Resources Management, Siem Reap, Cambodia, 2010); Jefferson Fox, Jean-Christophe Castella and Alan D Ziegler "Swidden, rubber and carbon: Can REDD+ work for people and the environment in Montane Mainland Southeast Asia?" Global Environmental Change.

${ }^{4} \mathrm{Li}$ and others, above $\mathrm{n}$ 2, at 1660; Schmidt-Vogt and others, above $\mathrm{n}$ 1, at 275; Van Vliet and others, above $\mathrm{n} 2$, at 4; Andrew Walker "Seeing farmers for the trees: Community forestry and the arborealisation of agriculture in northern Thailand" (2004) 45 Asia Pacific Viewpoint 311 at 314; Ellen, above n 2, at 26. 
time of transition. This thesis will discuss how swidden land use rights may be protected through integrating localised Customary Land Management (CLM) systems, which establish swidden land use rights, and the State Land Management (SLM) system. The goal of integrating these systems will be to enable customary land use rights over swidden land to be recognised as comprehensively as possible by the state. This will help prevent swidden farmers from being excluded from their land by third parties. However, the frameworks used to recognise CLM systems within the SLM system should allow sufficient flexibility for local farmers to adapt to changing circumstances.

(a) Structure of the thesis

The interaction between SLM and CLM systems in terms of the effect they have on accessing swidden cultivation is complex, multifaceted and influenced by a myriad of external factors. In order to comprehensively assess these relations, this thesis will take a socio-legal approach. It will consider the issue of property rights as a subset of the broader concept of access to resources. In doing so, it will focus on SLM and CLM systems as mechanisms enabling access to swidden land. However, it will assess these rights-based mechanisms within broader structural and relational mechanisms which influence the distribution of power and thereby the ability to access resources. The second chapter will discuss the theoretical framework this thesis will use to undertake this analysis.

As this thesis is specifically focused on customary land use rights over swidden land, the third chapter will discuss swidden cultivation. It will highlight some of the political, economic, demographic and socio-cultural factors that are affecting how swidden is practiced in Myanmar and the wider Southeast Asian region. ${ }^{5}$

Chapters four and five will respectively discuss CLM and SLM systems. Both types of land management system have changed over time. Although diverse, CLM systems in Myanmar have elements common to other CLM systems throughout Southeast Asia. ${ }^{6}$ Chapter four will outline some of these common elements. It will also describe more specifically how some CLM systems operate in Myanmar as well as how they have altered in response to external circumstances. Chapter five will traverse the radical shifts in the SLM system in Myanmar since pre-colonial times. Changes in state governance which have caused these shifts include the demise of the Burmese monarchy, colonisation, the division between the delta region and frontier areas of British Burma, independence, coups

\footnotetext{
${ }^{5}$ Fox and others, above n 2, at 306; Cramb and others, above n 2, at 326-8; Van Vliet and others, above n 2 , at 426.

${ }^{6}$ BH Baden-Powell The Land Systems of British India (Clarendon Press, Oxford, 1892) vol 3 at 493 ; RE Elson The end of the peasantry in Southeast Asia (MacMilllan Press, Houndmills (Hampshire), 1997) at 129.
} 
d'état, military governance and political reforms. ${ }^{7}$ These dramatic political transitions have altered state ideologies and objectives which have consequently led to constitutional, legislative and policy changes to the SLM system.

Chapter six will outline how CLM and SLM systems have interacted historically. Up to the present, SLM and CLM systems have been poorly integrated. The remoteness of Myanmar's hill country from economic markets and state political power has helped perpetuate CLM practices. ${ }^{8}$ However, the lack of integration between SLM and CLM systems in Myanmar has meant customary land use rights have little formal recognition. As the SLM system's ability to access swidden land has strengthened, the lack of integration between the systems has meant the SLM system is more likely to ignore CLM systems. Because of this, swidden land has been vulnerable to state restrictions in land use and exploitation by other parties. ${ }^{9}$

The shifts in the SLM system outlined in chapter four in combination with changes in political-economic circumstances and ideologies have influenced access to swidden land through CLM systems. There have been a wide range of these political-economic circumstances throughout Myanmar's history which have affected the relationship between SLM and CLM systems. The power embedded in CLM systems and the SLM system has waxed and waned along the drivers causing changes in swidden land use.

Since 2011, Myanmar has experienced a period of political and economic transition as it moves towards a more democratic government and liberalised economic system. ${ }^{10} \mathrm{In}$ an effort to modernise laws governing agriculture, the Myanmar government enacted two pieces of legislation in 2012 which significantly altered the SLM system. ${ }^{11}$ Chapter seven will outline the features of the Farmland Law 2012 (Farmland Law 2012) and the Vacant Fallow and Virgin Lands Management Law 2012 (VFV Law) and their implementing rules.

\footnotetext{
${ }^{7}$ Robert H Taylor The state in Myanmar (Hurst, London, 2009); Martin John Smith Burma (University Press, 1991); Bertil Lintner Burma in Revolt (Silkworm Books, 1999); Ian Brown Burma's economy in the twentieth century (Cambridge University Press, Cambridge, United Kingdom, 2013); Thant Myint-U The making of modern Burma (Cambridge University Press, New York, 2001); Melissa Crouch and Timothy Lindsey Law, society and transition in Myanmar (Hart Publishing, Oxford, 2014).

${ }^{8}$ Monique Skidmore and Trevor Wilson Myanmar (Asia Pacific Press and Australian National University E Press, Canberra, 2007) at 279; Burma Environmental Working Group Burma's environment (The Burma Environmental Working Group, Chiang Mai, 2011) at 37-38.

${ }^{9}$ Nancy Hudson-Rodd and others "The impact of the confiscation of land, labor, capital assets and forced relocation in Burma by the military regime" (2003) NCUB/FTUB discussion paper 〈http://www.burmalibrary.org/docs/land_confiscation1-20.pdf>.

${ }^{10}$ See Crouch and Lindsey and Jones for a discussion of Myanmar's political and economic transition and potential trajectory. Crouch and Lindsey, above n 7; Lee Jones "The Political Economy of Myanmar's Transition" (2014) 44 Journal of Contemporary Asia 144.

${ }^{11}$ Farmland Law 2012 (Myanmar); Vacant, Fallow and Virgin Land Management Law 2012 (Myanmar).
} 
Chapter eight will then analyse how Myanmar's 2012 land law reforms have affected the recognition of customary land rights and swidden land use there. It will summarise how customary land use rights are currently recognised. Analysis of this legislation will focus on three areas of weakness in addressing customary land use rights over swidden land. These areas are very unclear under the current SLM system. They are: firstly, how land under customary tenure is identified; secondly, how communally-held land is recognised; and finally, what swidden activities are legally permitted.

After analysing both the historical and current interaction between CLM and SLM systems, the final chapter will then propose the foundation for further legislative reforms. The discussion will focus on the three identified areas of weakness in the current SLM system. It will apply research about the formalisation of customary land use rights and assess any progress made in Myanmar's recent draft National Land Use Policy (NLUP). The discussion will use examples of how this has been achieved in the Philippines and Cambodia.

It will propose reforms in light of the broader changes affecting swidden cultivation in Myanmar. Firstly, the identification of swidden land will be considered in the context of producing maps of customary land use. Secondly, the management of swidden land under collective land-holding structures will be discussed with regard to pressures to individualise land-holding. Thirdly, the use of swidden cultivation practices will be considered in light of proposed development projects.

The ultimate goal of these proposed reforms is for customary land use rights over swidden land to be more comprehensively recognised and protected within the SLM system through a period of transition.

\section{$1 \quad$ Limits to the thesis}

(a) The goal of recognising customary land use rights

Scholarship surrounding the recognition of customary land use rights has been written with different goals in mind. The focus of literature includes sustainable development, ${ }^{13}$

\footnotetext{
12 Farmland Rules 2012 (Myanmar); Vacant, Fallow and Virgin Land Management Rules 2012 (Myanmar).

${ }^{13}$ Displacement Solutions "Myanmar at the HLP Crossroads: Proposals for Building an Improved Housing, Land and Property Rights Framework that Protects the People and Supports Sustainable Economic Development" (October 2012) <http://displacementsolutions.org/files/documents/MyanmarReport.pdf>; Eberhardt, above n 1; Peter Ørebech and others The Role of Customary Law in Sustainable Development (Cambridge University Press, Cambridge (UK), 2005).
} 
economic efficiency, ${ }^{14}$ encouraging social equity ${ }^{15}$ and environmental conservation. ${ }^{16}$ However, the focus of this thesis is limited to comprehensively recognising customary land rights within a SLM system during a period of economic transition. There may be economic or environmental benefits in doing so. However, the purpose of proposed reforms will not be in order to spur economic growth, promote more efficient land use or encourage environmental protection. Rather, the proposed reforms will aim to achieve the most comprehensive recognition of customary land use rights within the SLM system, while also allowing sufficient flexibility to transition from more traditional types of land use. The process of formalising CLM systems into the SLM system outlined in this thesis will aim to follow or move with agricultural transition, rather than encourage it.

Likewise, although the issue of enforcement mechanisms and the operation of the rule of law are also essential to the successful implementation of reforms to the SLM system, ${ }^{17}$ this will go beyond the scope of this thesis.

(b) Models for recognising customary land use rights

Anderson distinguishes between two main frameworks in which customary land use rights are recognised by States in Southeast Asia. The first provide permanent tenure and the second, temporary tenure through the delegated management of land resources for a set amount of time. ${ }^{18}$

Although, prior to 2012, Myanmar's 1995 Community Forestry Instructions (CFI) were relied on as one of the only means available to recognise customary land use rights, they were recognised as a necessary compromise. ${ }^{19}$ However, temporary models only partially address the need for tenure security in indigenous Southeast Asian contexts. ${ }^{20}$

\footnotetext{
14 Anna Locke Property rights and development briefing: Property rights and economic growth (Overseas Development Institute, 2013); Harold Demsetz "Toward a Theory of Property Rights" (1967) 57 The American Economic Review 347.

${ }^{15}$ Displacement Solutions, above n 13, at 22.

${ }^{16}$ Peter Eaton Land Tenure, Conservation and Development in Southeast Asia (Routledge, 2013); Daniel W Bromley Environment and economy (Blackwell, Oxford, 1991); Thilde Bech Bruun and others "Environmental Consequences of the Demise in Swidden Cultivation in Southeast Asia: Carbon Storage and Soil Quality" (2009) 37 Human Ecology 375; Tun Myint "A Perspective on Burma" in Advancing Environmental Governance: Perspectives from the Regional Environmental Forum for Mainland Southeast Asia (2003); Jefferson Fox and others Rubber plantations expand in mountainous Southeast Asia: what are the consequences for the environment? (2014).

${ }^{17}$ John W Bruce and others Land law reform (World Bank, Washington, DC, 2006) at 112.

${ }^{18}$ Kirsten Ewers Anderson Communal Tenure and the Governance of Common Property Resources in Asia: Lessons from Experiences in Selected Countries (Food and Agriculture Organization of the United Nations, 2011) at 3.

${ }^{19}$ Woods, above n 3, at 8; Burma Environmental Working Group, above n 8, at 35.

${ }^{20}$ Tania Murray Li "Engaging Simplifications: Community-Based Resource Management, Market Processes and State Agendas in Upland Southeast Asia” (2002) 30 World Development 265 at 266.
} 
Various issues have been raised by writers about converting swidden land into Community Forests. $^{21}$

(c) Indigenous rights

The issue of indigenous rights is closely connected to CLM systems. ${ }^{22}$ Groups who manage resources through CLM systems are often ethnic minorities living in ancestral tribal areas. The recognition of customary land use rights is therefore frequently framed around arguments of indigeneity. The recognition of customary land rights has been highlighted as a specific issue facing indigenous populations. ${ }^{23}$ However, United Nations documents containing clauses relating to customary land rights have been aimed at more broadly recognising indigenous people's rights. ${ }^{24}$

In an Asian context, the issue of indigeneity is more convoluted. ${ }^{25}$ A number of states in Asia have resisted recognising the term "indigenous peoples." 26 Myanmar's response, similar to India, Myanmar, Indonesia, and Bangladesh, has been to argue that their entire population is "indigenous" and that distinctions along these lines cannot be made. ${ }^{27}$ Anaya, the United Nations Special Rapporteur on the rights of indigenous peoples, acknowledges the arguments surrounding definitions. However, he emphasises that issues facing groups in other countries who are recognised as indigenous peoples are similar to those faced by minority ethnic groups in Asian countries. ${ }^{28}$ In Myanmar, these groups are referred to as ethnic nationalities or, officially, national races. ${ }^{29}$

\footnotetext{
${ }^{21}$ Woods, above n 3, at 2; Kyaw Tint, Oliver Springate-Baginski and Ko Ko Gyi Mehm Community Forestry in Myanmar: Progress \& Potentials (ECCDI, 2011).

${ }^{22}$ Tony Burns and others Land administration reform: indicators of success and future challenges (World Bank, 2007).

${ }^{23}$ SJ Anaya Report of the Special Rapporteur on the rights of indigenous peoples, James Anaya, on the consultation on the situation of indigenous peoples in Asia A/HRC/24/41/Add.3 (2013) at 6.

${ }^{24}$ Convention concerning Indigenous and Tribal Peoples in Independent Countries, International Labour Organisation 1650 UNTS 383 (adopted 27 June 1989, entered into force 5 September 1991); United Nations Declaration on the Rights of Indigenous Peoples (2007) GA Res 61/295, A/61/L.67 and Add.1; See the following for more details about relevant international materials affecting indigenous land rights in Southeast Asia: Alexandra Xanthaki "Land Rights of Indigenous Peoples in South-East Asia" (2003) 4 Melb J Int'l L 467; Isabel Inguanzo "Indigenous Peoples' Rights in Southeast Asia" (2014) 22 Asian Journal of Political Science 45 .

${ }^{25}$ Yogeswaran Subramaniam "The ASEAN human rights declaration and indigenous rights” (2013) 8 ILB 3 at 4 .

${ }^{26}$ Francesca Merlan "Indigeneity: Global and Local" (2009) 50 Current Anthropology 303 at 303; Marcus Colchester "Indigenous peoples and communal tenures in Asia" (2004) 1 Land Reform 28 at 29-30.

${ }^{27}$ Bruce Granville Miller Invisible Indigenes (University of Nebraska Press, 2003) at 165-166; Merlan, above n 26, at 318 .

${ }^{28}$ Anaya, above $\mathrm{n} 23$, at 5-6.

${ }^{29}$ Constitution of the Republic of the Union of Myanmar 2008 (Myanmar).
} 
Due to the conflicting discourses surrounding indigeneity, rights to land in this thesis will not be framed around arguments based on indigeneity. This would distract from the main line of argument and space does not permit an adequate discussion of the arguments surrounding indigeneity in Asia. In the recent NLUP the Myanmar government has moved towards recognising land use rights possessed by 'ethnic nationalities.' ${ }^{30}$ However, it is still unclear who is included in this category. ${ }^{31}$ Also, analysing land rights in Myanmar from this perspective would limit the applicability of the thesis to the rest of Myanmar's legal history. This is because land rights in Myanmar within the SLM system have not been connected to indigeneity until the drafting of the NLUP.

The customary land use rights referred to in this thesis will be derived from CLM systems, rather than indigenous identity.

(d) International legal instruments

As this thesis will analyse the interaction between SLM and CLM systems, it will not focus on how these systems interact with international legal instruments and processes. Although international law has an important place in situations of legal plurality, ${ }^{32}$ Myanmar has had very limited interaction with international agreements. ${ }^{33}$ Furthermore, incorporating a third rights-based mechanism, that is, international law, into the analysis would add a further level of complexity for which there is insufficient space to deal with. This thesis will not discuss the claims Myanmar citizens may in domestic or international courts or tribunals regarding customary land rights based on international law. ${ }^{34}$

\footnotetext{
${ }^{30}$ Government of the Republic of the Union of Myanmar Land Use Allocation and Scrutinizing Committee National Land Use Policy (English) (2014) at Part VII.

31 For example, whether it includes the ethnic "Bamar" majority. TNI Myanmar Programme and TNI Agrarian Justice Programme Pro-business or pro-poor? Making sense of the recently unveiled draft National Land Use Policy (Transnational Institute, 2014) at 11; Sandar Lwin “"Ancestral' lands to be protected under draft policy" The Myanmar Times (Myanmar, 5 December 2014) <http://www.mmtimes.com/index.php/national-news/12440-ancestral-lands-to-be-protected-under-draftpolicy.html>.

${ }^{32}$ Ruth S Meinzen-Dick and Rajendra Pradhan Legal pluralism and dynamic property rights (CAPRi, 2002) at 4; Convention concerning Indigenous and Tribal Peoples in Independent Countries, Art 14(1).

${ }^{33}$ Inguanzo, above n 24.

${ }^{34}$ See Roy for discussion of the application of international legal documents to the recognition of indigenous land rights in the Chittagong Hill Tracts Rajkumari Chandra Kalindi Roy Land rights of the indigenous peoples of the Chittagong Hill Tracts, Bangladesh (Iwgia, 2000).
} 


\section{Theoretical framework}

\section{Customary land rights as a 'bundle of rights'}

The subjects of property rights and property relations have been extensively discussed and theorised through Western history. Prominent thinkers such as Locke, Bentham and Proudhon conceptualised aspects of property rights and relations. Locke described property as involving the mixing of labour with land. Bentham followed a utilitarian approach, that certain models of tenure are more efficient in certain situations. Proudhon questioned founding property on occupation, law or labour. ${ }^{35}$ Each of these thinkers struggled with viewing property simply as a 'legal right'. Instead, they saw the relational aspects involved in the management of resources, in particular land. ${ }^{36}$

A metaphor that emerged in the $19^{\text {th }}$ Century to describe property interests is that of a "bundle of rights". This phrase and has become a starting point in modern conceptions of property rights. ${ }^{37}$ The bundle of rights metaphor has been criticised for being loose, obscure and "confusing the boundaries between property rights and other normative relations." ${ }^{38}$ However, it remains a useful tool in analysing property as it is capable of containing both the rights and relations aspects of property.

The term "bundle of rights" has been used in conjunction with CLM systems. These complex tenure arrangements are usually locally and relationally specific and contain a mixture of individual and collective land use rights as well as other administrative and usage rights. ${ }^{39}$ Eaton uses this analogy when describing traditional tenure systems in Southeast Asia. ${ }^{40}$ Descriptions of CLM systems specifically in Myanmar have also used the 'bundle of rights' analogy. ${ }^{41}$

The metaphor is able to be extended in order to express the intricacies of a CLM

\footnotetext{
${ }^{35}$ Jesse C Ribot and Nancy Lee Peluso "A Theory of Access" (2003) 68 Rural sociology 153 at 155-157; See Alexander for details about historical understandings of property Gregory S Alexander and Eduardo Moisés Peñalver An Introduction to property theory (Cambridge University Press, Cambridge, 2012).

${ }^{36}$ Ribot and Peluso, above n 35, at 155-157.

${ }^{37}$ Michael A Heller "The Boundaries of Private Property" (1999) 108 The Yale Law Journal 1163 at 712; For example see the following general property texts: Lawrence C Becker Property Rights (Routledge, 2014); Stephen R Munzer A Theory of Property (Cambridge University Press, 1990); Jeremy Waldron The Right to Private Property (Clarendon Press, 1990).

${ }^{38}$ Heller, above n 37, at 724.

${ }^{39}$ Tania Murray Li "Indigeneity, Capitalism, and the Management of Dispossession" (2010) 51 Current Anthropology 385 at 401; Klaus W Deininger and others "Innovations in land rights recognition, administration, and governance" [2010] Joint Organizational Discussion Paper - Issue 2 at ch 3.

${ }^{40}$ Mark Cleary and Peter Eaton Tradition and reform (Oxford University Press, 1996) at 48; Eaton, above n 16 , at 8 .

${ }^{41}$ Food Security Working Group Upland Land Tenure Security in Myanmar: An overview (Food Security Working Group, 2011) at 3; Woods, above n 3, at 8.
} 
system. Conceptualising complex customary land rights as bundles enables them to be broken down into smaller components. ${ }^{42}$ This is particularly relevant for CLM systems as different individuals and groups may exercise different rights over land. ${ }^{43}$

Benda-Beckmann emphasises that models assessing Asian and African tenure systems should not try and shoe-horn ideas from these systems through inflexible, ethnocentric western European concepts. Instead, conceptual frameworks should be broad enough to capture the wide variety of types of tenure and assess the similarities and differences that emerge. ${ }^{44}$ The "bundle of rights" analogy provides a sufficiently flexible framework from which to assess complex customary land rights.

\section{$2 \quad$ Legal pluralism}

This thesis will assess the interaction between SLM systems and CLM systems controlling swidden land use. From the early $20^{\text {th }}$ century, thinkers have framed discussions the interaction of different legal systems in terms of legal pluralism. ${ }^{45}$ This became more prevalent after World War II. ${ }^{46}$ Legal pluralism was used particularly in analysing the legal systems in colonial or former colonial countries, as their legal systems often contained a mixture of both customary law and state legislation. However, the discipline has developed more broadly into assessing how state power may be contested through localised norms. ${ }^{47}$

Merry defines legal pluralism as "a situation in which two or more legal systems coexist in the same social field." ${ }^{48}$ Hooker states that it incorporates circumstances "in the contemporary world which have resulted from the transfer of whole legal systems across cultural boundaries." ${ }^{49}$ Within contemporary Myanmar, the patchwork of colonial and post-colonial legislation and policy forming the SLM system has extended beyond its precolonial boundaries and has contested localised CLM systems. The interaction between Myanmar's SLM and CLM systems provide a clear example of legal plurality.

\footnotetext{
42 Arun Agrawal and Elinor Ostrom "Collective Action, Property Rights, and Decentralization in Resource Use in India and Nepal” (2001) 29 Politics Society 485 at 489; Cleary and Eaton, above n 40, at 48; Deininger and others, above n 39.

${ }^{43}$ Deininger and others, above $\mathrm{n} 39$, at 36.

${ }^{44}$ Franz von Benda-Beckmann "Anthropological Approaches to Property Law and Economics" [1995] European Journal of Law and Economics at 311-312.

${ }^{45}$ For more information about legal pluralism, see: David S Clark "Pluralism, Legal" in Encyclopedia of Law and Society: American and Global Perspectives (SAGE Publications, Thousand Oaks, CA, 2007) 1116 Gale Virtual Reference Library; Meinzen-Dick and Pradhan, above n 32; Sally Engle Merry "Legal Pluralism" (1988) 22 Law \& Society Review 869; MB Hooker Legal pluralism (Clarendon Press, 1975).

${ }^{46}$ Clark, above n 45.

${ }^{47}$ Brian Z Tamanaha A General Jurisprudence of Law and Society (Oxford University Press, 2001).

${ }^{48}$ Merry, above n 45, at 870 .

${ }^{49}$ Hooker, above n 45, at 1.
} 
Legal plurality can be conceptualised in terms of power relations between different forms of legal system. ${ }^{50}$ Legal rights which flow from different legal systems are not equally powerful. The amount of power which may be exercised through a certain system is also dependent on an institution or group who is able to enforce these legal claims. ${ }^{51}$

\section{Access as a "bundle of powers"}

In order to capture the multifaceted nature of property relations in developing countries, thinkers have used socio-legal frameworks. For example, Hall et al structure their analysis in terms of exclusion. They define exclusion as prevention from being able to access benefits, specifically from land. ${ }^{52}$ The recognition of rights over land comes with the converse ability to exclude others from obtaining these rights. ${ }^{53}$

Building on critical legal, sociological and political thought through the 1980s and 1990s, Ribot and Peluso brought together the concepts of tenure as a 'bundle of rights' and power relations in their access model. ${ }^{54}$ They define access as "the ability to benefit from things." ${ }^{55}$ They use the term 'ability' instead of 'right' because 'ability' incorporates power into the model. ${ }^{56}$ It moves beyond a solely rights-based analysis of resource use into one that takes account of power relations. Access is framed as a 'bundle of powers.' 57 This covers situations where individuals may hold a legal right to use a resource; however, for some reason they are unable or unwilling to exercise this right. ${ }^{58}$ For example, if someone has a customary land claim over a piece of land that is confiscated, they are unable to exercise their customary right to use this land.

\footnotetext{
${ }^{50}$ Merry, above n 45.

${ }^{51}$ Meinzen-Dick and Pradhan, above n 32, at 4-5.

52 Derek Hall, Philip Hirsch and Tania Li Powers of exclusion (NUS Press, Singapore, 2011) at 7-8.

${ }^{53}$ Philip Hirsch and Carol Warren The Politics of Environment in Southeast Asia (Routledge, 2002 ) at 14.

${ }^{54}$ Ribot and Peluso, above n 35, at 158.

55 At 153.

${ }^{56}$ At 155.

57 At 173; Janet C Sturgeon and Thomas Sikor "Post-socialist Property in Asia and Europe: Variations on Fuzziness" (2004) Volume 2 Conservation and Society 1.

${ }^{58}$ Ribot and Peluso, above n 35, at 160.
} 
The diagram below illustrates the various components of Peluso and Ribot's access model:

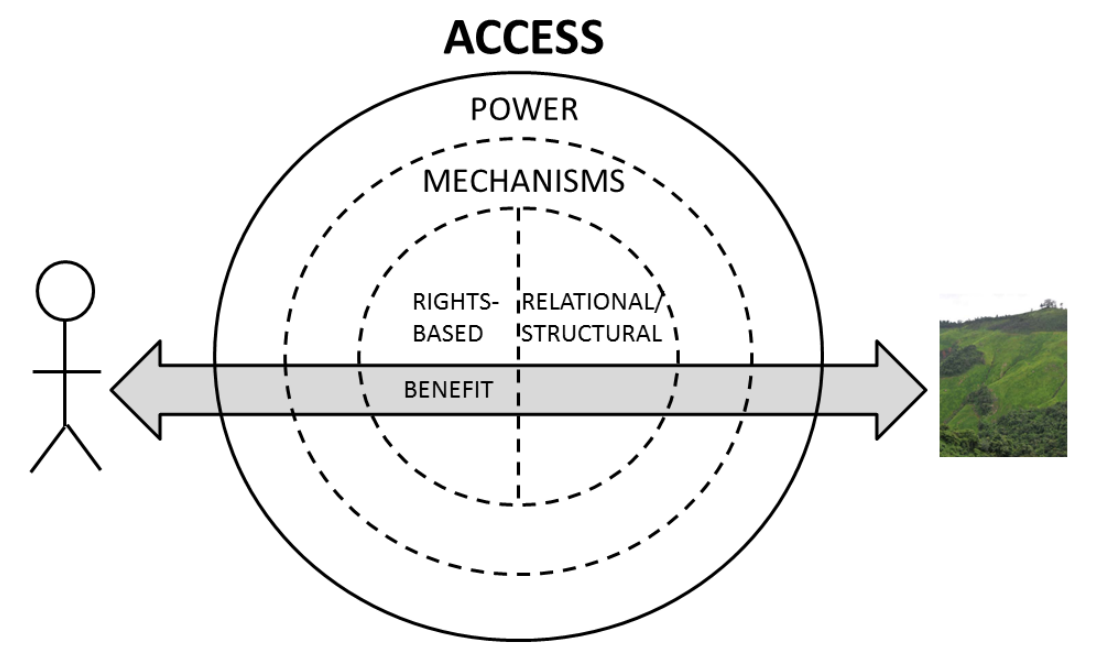

Diagram 1: Access model (created by the author based on Ribot and Peluso)

In general terms, access processes and relations form and are shaped by interrelated mechanisms enabling actors to use and benefit from resources. These mechanisms may be rights-based or relational/structural. ${ }^{59}$ Together, they form the "bundles of power" held by individuals, groups or institutions and used to access resources.

Applying their model to this thesis, the 'actors' are swidden farmers, the 'thing' is swidden land held under customary tenure and the 'benefit' is practicing swidden cultivation in order to support farmers' livelihoods.

SLM and CLM systems are both rights-based mechanisms of access. ${ }^{60}$ They can be assessed as individual strands within the bundles of power possessed by landholders through which they are able to use and benefit from swidden land. ${ }^{61}$ These systems are able to operate in parallel, compete against or cooperate with each other. ${ }^{62}$

Structural-relational mechanisms are configured by external circumstances, which directly affect the ability of actors to benefit from swidden land through rights-based mechanisms. ${ }^{63}$ Strands of power shift and change over time and geographic distance, which alters the nature of power and forms of access. ${ }^{64}$ The access model therefore represents a useful model by which to assess the interaction between SLM and CLM systems in Myanmar both historically and in the present day.

\footnotetext{
${ }^{59}$ At $161-162$.

${ }^{60}$ At 161.

${ }^{61}$ At 158.

${ }^{62}$ At 173 .

${ }^{63}$ At 154 and 173.

${ }^{64}$ At 154.
} 
This thesis will highlight four particular drivers which have affected swidden cultivation and CLM systems through history. They are economic, political, demographic and sociocultural circumstances.

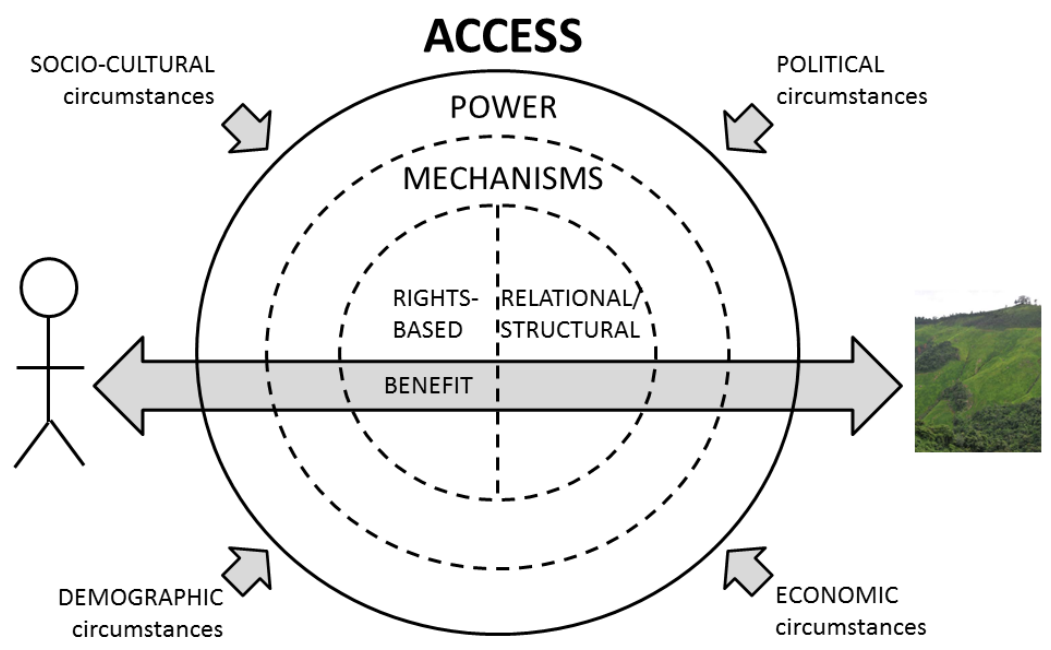

Diagram 2: Access model with external drivers (created by the author based on Ribot and Peluso)

The analysis in this thesis will focus on the interaction between SLM and CLM systems as strands of power used to access swidden land. It will consider how these two mechanisms of access have interacted over time. They can be assessed with regard to the myriad of political, economic, demographic and socio-cultural circumstances which have affected access. The results can then be applied in order to understand factors which are causing the SLM system to become an increasingly dominant mechanism of access to swidden land.

Ribot and Peluso's access model has been constructed to analyse any aspect of resource use. However, it appears to have emerged from a significant amount of research comprehending the complex processes and relations surrounding resource use in Southeast Asia. ${ }^{65}$ Because of this, the model provides sufficient structural clarity in order to meaningfully analyse the interaction between CLM and SLM systems in Myanmar, while still remaining sufficiently flexible to include the complex and shifting factors influencing these systems.

\section{$4 \quad$ From conflicting to complementing}

Mechanisms of access may interact in various ways. For example, they may conflict with

\footnotetext{
${ }^{65}$ Nancy Lee Peluso Rich Forests, Poor People (University of California Press, 1994); Cramb and others, above n 2; Fox and others, above n 2; Nancy Lee Peluso and Christian Lund New Frontiers of Land Control (Routledge, 2013); Nancy Lee Peluso and Peter Vandergeest "Genealogies of the political forest and customary rights in Indonesia, Malaysia, and Thailand" (2001) 60 The Journal of Asian Studies 761; Peter Vandergeest and Nancy Lee Peluso "Territorialization and state power in Thailand" (1995) 24 Theory and society 385 .
} 
or complement each other. ${ }^{66}$ The interaction between SLM and CLM systems can be assessed in light of these relational patterns.

In circumstances where CLM and SLM systems are conflicting, the ability of customary rights holders to access swidden land will depend on the power embedded in either mechanism. The destabilisation of conflicting mechanisms of access through shifts in power creates 'fuzziness' within tenure relations which may be manipulated by local elites. ${ }^{67}$

If customary land rights over swidden land are to be formally recognised and protected through a period of transition, CLM and SLM systems must move from conflicting, and towards complementary mechanisms of access. This links the access model with research around the formalisation of customary land rights. The process of formalisation will be discussed further in Chapter 9. The proposed reforms in this thesis will therefore be measured by how effectively they enable the SLM system to complement CLM systems.

\footnotetext{
${ }^{66}$ Ribot and Peluso, above $\mathrm{n} 35$, at 155.

${ }^{67}$ Sturgeon and Sikor, above n 57, at 15.
} 


\section{Swidden cultivation}

$1 \quad$ Swidden defined

Swidden cultivation is a common form of traditional subsistence agriculture which is practiced globally. ${ }^{68}$ It involves a section of land being cleared and burned before it is cropped. Once cultivation has been completed the land is then left to fallow and revert back to scrub or degraded forest. Swiddeners then rotate to another section of land and begin the process of clearing, burning and cropping again. After leaving a section in an extended fallow, they will rotate back to the original clearing and begin the cycle again. Mertz et al provide a broad working of swidden cultivation as: ${ }^{69}$

...[A] land use system that employs a natural or improved fallow phase, which is longer than the cultivation phase of annual crops, sufficiently long to be dominated by woody vegetation, and cleared by means of fire.

Several other phrases have been used to describe this process. They include shifting cultivation, rotational cultivation and slash-and-burn. ${ }^{70}$ Traditional communities also describe the practice in their own languages. ${ }^{71}$ The variety of terminology and definitions has caused writers to debate which best describes the form of traditional cultivation in Southeast Asia. ${ }^{72}$

Writers during the 1960s resisted the term "swidden" as it was viewed as an obsolete Old English term. ${ }^{73}$ However, it is now commonly used in academic writing. Some writers use swidden and shifting cultivation synonymously. ${ }^{74}$ However, others refer to swidden as

\footnotetext{
${ }^{68} \mathrm{Li}$ et al state that traditional swiddening is carried out in 40-50 countries by almost half a billion people. Swidden cultivators live in the hilly regions of Latin America, Central Africa and South East Asia. Li and others, above n 2, at 1655 .

${ }^{69}$ Ole Mertz and others "Swidden Change in Southeast Asia: Understanding Causes and Consequences" (2009) 37 Human Ecology 259 at 261; Van Vliet and others, above n 2, at 2.

${ }^{70} \mathrm{Li}$ and others, above $\mathrm{n} 2$, at 1657-8; Mertz and others, above $\mathrm{n}$ 69, at 260-1.

${ }^{71} \mathrm{Li}$ and others, above n 2, at 1657; For example, "kaingin" in the Philippines, Harold Olofson "Swidden and kaingin among the Southern Tagalog: A problem in Philippine upland ethno-agriculture" (1980) 8 Philippine Quarterly of Culture and Society 168; "Ladang" in Indonesia, Ellen, above n 2, at 19; and "Jhum" in Northeastern India, PS Ramakrishnan and OP Toky "Soil nutrient status of hill agro-ecosystems and recovery pattern after slash and burn agriculture (Jhum) in north-eastern India" (1981) 60 Plant Soil 41.

${ }^{72}$ For discussion about definitions see: Mertz and others, above $\mathrm{n}$ 69, at 260-261; Li and others, above $\mathrm{n} 2$, at 1657-1658; Malcolm F Cairns Shifting Cultivation and Environmental Change (Routledge, 2015) at 2627.

${ }^{73}$ Olofson, above $\mathrm{n} 71$, at 168 .

${ }^{74}$ For example see: Christine Padoch and others "The Demise of Swidden in Southeast Asia? Local Realities and Regional Ambiguities" (2007) 107 Geografisk Tidsskrift-Danish Journal of Geography 29; Peter Boomgaard "Long-Term Changes in Land-Tenure Arrangements in Pre-Modern and Early-Modern Southeast Asia: An Introduction" (2011) 54 Journal of the Economic \& Social History of the Orient 447 at 450; Fox, Castella and Ziegler, above n 3.
} 
a subset of shifting cultivation. ${ }^{75}$ There are two specific aspects which distinguish swidden cultivation from other forms of shifting cultivation. Firstly, it incorporates the use of fire to clear land before planting ${ }^{76}$ and, secondly, it associates the practice with indigenous traditions. ${ }^{77}$ These distinctions mean 'swidden' or 'swidden cultivation' is preferred when specifically describing the process in Southeast Asia. ${ }^{78}$

The issue of definitions is muddied further in Myanmar. This is because the Burmese word commonly used to mean swidden cultivation is taungya. ${ }^{79} \& 80$ This word is the contraction of taung meaning 'hill' and ya meaning 'cultivation'. ${ }^{81}$ However, taungya is also a generic word used for any type of agriculture carried out on upland sloping fields, not just swidden cultivation. ${ }^{82}$ The more specific Burmese phrase for swidden is 'shwe pyaung taungya'. 83 \& 84 The draft National Land Use Policy also uses other generalised phrases when referring to swidden cultivation. $85 \& 86$

Not only does taungya refer to hill-side cultivation in general, it is also used to describe the forest management system the British established in the mid-19 ${ }^{\text {th }}$ century. In the colonial taungya system, British colonialists paid swiddeners to plant and tend teak

\footnotetext{
${ }^{75}$ Ole Mertz "The relationship between length of fallow and crop yields in shifting cultivation: a rethinking" (2002) 55 Agroforestry systems 149 at 150.

${ }^{76}$ As opposed to fire-free, mulch-based shifting cultivation, such as in the Pacific Islands. Mertz and others, above n 69, at 260 .

${ }^{77} \mathrm{Li}$ and others, above n 2, at 1657 and 1672; Meine van Noordwijk and others Swiddens in transition (World Agroforestry Centre, Bogor (Indonesia), 2008) at x.

${ }^{78}$ Mertz and others, above n 69, at 260-1.

${ }^{79}$ Burmese: 600 ćcos.

${ }^{80}$ Woods, above n 3 , at 3.

${ }^{81}$ Raymond L Bryant "Shifting the Cultivator: The Politics of Teak Regeneration in Colonial Burma" (1994) 28 Modern Asian Studies 225 at 225-6.

${ }^{82}$ Food Security Working Group, above $n$ 41, at iv .

${ }^{83}$ San Win Investigation on shifting cultivation practices conducted by the hill tribes for the development of suitable agroforestry techniques in Myanmar (Forest Department, 2004) at 3; Ei Ei Swe Hlaing "Facilitating Decentralized Policy for Sustainable Forest Governance in Myanmar : Lessons from the Philippines" (Thesis, 2013) at 23-24; Land Core Group of the Food Security Working Group 13 Case Studies of Land Confiscations in Three Townships of Central Myanmar (Food Security Working Group, 2012) at 19.

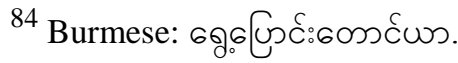

85 Such as $600 \hat{\varepsilon}$ cos under the broader phrase translated 'lands cultivated by traditional methods.'

${ }^{86}$ Government of the Republic of the Union of Myanmar Land Use Allocation and Scrutinizing Committee, above $\mathrm{n}$ 30, at subs 33(d); In the Burmese original it is s 34(d) Government of the Republic of the Union of Myanmar Land Use Allocation and Scrutinizing Committee National Land Use Policy (Myanmar) (2014). The numbering in the sections in the English translation is one less than the Burmese original. This is the case in the rest of the citations in this thesis.
} 
trees amongst their crops after clearing the land, in order to re-establish teak forests. ${ }^{87}$ The importance of these differences will become apparent in Chapter 8.

In this thesis, I will use 'swidden' or 'swidden cultivation' to describe the traditional agricultural practice and 'taungya teak planting' to describe its colonial adaption.

\section{Swidden in South East Asia}

Swidden is practiced in many parts of Southeast Asia. ${ }^{88}$ Schmidt-Vogt et al state that swidden is practiced, although not exclusively, on nearly 50 per cent of the land area in South East Asia. ${ }^{89}$ It is also described as the dominant form of land use in the mountainous areas of South East Asia. ${ }^{90}$ Swidden is a rational choice of land use for traditional, closeknit forest farming communities living in isolated areas with low population density and poor soil quality. ${ }^{91}$ There is, however, widespread agreement that swiddening is changing significantly throughout the South East Asian region. ${ }^{92}$

(a) Drivers of change

There is a lack of detailed information about the driving factors causing changes in swiddening in South East Asia. ${ }^{93}$ Analysis of changes in swidden stem from Boserup's model, which connected agricultural development with social and environmental conditions. In particular, she highlighted the links between population change, labour intensity and the adoption of more productive agricultural technologies. ${ }^{94}$ Drawing on research produced since this then, Fox et al, ${ }^{95} \mathrm{Cramb}$ et al ${ }^{96}$ and Van Vliet et al ${ }^{97}$ have highlighted some major causative factors within Southeast Asia. However, these factors are

\footnotetext{
${ }^{87}$ Bryant, above n 81, at 225-226; Tin Min Maung and Miho Yamamoto "Exploring the Socio-Economic Situation of Plantation Villagers: A Case Study in Myanmar Bago Yoma” (2008) 7 Small-scale Forestry 29 at 32 .

${ }^{88}$ Ellen, above $\mathrm{n} 2$, at 32; Li and others, above $\mathrm{n} 2$.

${ }^{89}$ Schmidt-Vogt and others, above n 1, at 271.

${ }^{90} \mathrm{Li}$ and others, above $\mathrm{n}$ 2, at 1654.

${ }^{91}$ Van Vliet and others, above n 2, at 419; Ellen, above n 2, at 33.

${ }^{92}$ Cramb and others, above n 2; Fox and others, above n 2; Li and others, above n 2; Mertz and others, above n 2; Schmidt-Vogt and others, above n 1; Van Vliet and others, above n 2; Van Vliet and others, above n 2; Ziegler, Fox and $\mathrm{Xu}$, above n 2; Ellen, above n 2, at 26; Jonathan Rigg "Poverty and livelihoods after fulltime farming: A South-East Asian view” (2005) 46 Asia Pacific Viewpoint 173 at 173.

93 G Rasul and GB Thapa "Shifting cultivation in the mountains of South and Southeast Asia: regional patterns and factors influencing the change" (2003) 14 Land Degradation \& Development 495 at 497 ; Li and others, above n 2, at 1669; Schmidt-Vogt and others, above $\mathrm{n} 1$.

${ }^{94}$ Ester Boserup The conditions of agricultural growth (Allen \& Unwin, London, 1965).

${ }^{95}$ Fox and others, above n 2 , at 306.

${ }^{96}$ Cramb and others, above $\mathrm{n}$ 2, at 326-8.

${ }^{97}$ Van Vliet and others, above n 2, at 426.
} 
extrapolated from available data covering a variety of countries in Southeast Asia. The broad categories therefore overlook some of the nuances, complexity and diversity contained in country-specific scenarios. ${ }^{98}$ These authors noted that changes in swidden cultivation are not uniform. However, Van Vliet's meta-analysis reveals an apparent declining trend in swidden. ${ }^{99}$

The change factors noted by Fox et al, Cramb et al and Van Vliet et al can be summarised and clustered into four main areas. They are: political, economic, demographic and socio-cultural factors. All of these factors are interrelated and work in combination with each other. 100

Identified political drivers can be direct, such as restricting swidden practices. However, they can also be indirect, such as expanding forest departments, increasing conservationism, imposing rigid land classification systems or not recognising customary land rights. ${ }^{101}$ These processes work together to decrease the incidence of swiddening. For example, the re-classification of land, such as the expansion of protected areas, extends and strengthens the enforcement of regulations on swidden practices. ${ }^{102}$

Economic drivers affecting swidden cultivation relate to communities becoming more integrated with markets. Integration is increased by infrastructural expansion in the form of roads and industrial agriculture facilities. This process also promotes the privatisation and commoditization of land and land-based production. ${ }^{103}$ These economic forces move swiddeners towards cash-cropping and shorter fallow periods ${ }^{104}$ which results in more permanent land use.

Governments throughout Southeast Asia have long promoted the sedentarisation of swidden farming. ${ }^{105}$ Their policies have also encouraged these transitions. ${ }^{106}$ This causes a reduction in reliance on swidden cultivation as land users focus time and resources on cultivating cash crops. However, greater reliance on cash cropping does not result in immediate eradication of swidden plots. Rather, as discussed below, both permanent and swidden cultivation is frequently practiced together. Swidden represents a form of

\footnotetext{
${ }^{98} \mathrm{Li}$ and others, above $\mathrm{n} 2$, at 1670.

${ }^{99}$ Van Vliet and others, above n 2, at 426; Li and others, above n 2, at 1659.

${ }^{100}$ Van Vliet and others, above $\mathrm{n} 2$, at 420.

${ }^{101}$ Cramb and others, above n 2, at 328; Fox and others, above n 2, at 308; Van Vliet and others, above n 2 , at 422 .

102 Fox and others, above n 2, at 319.

${ }^{103}$ At 310-312; Cramb and others, above n 2, at 327-328.

${ }^{104}$ Cairns, above n 72, at 28.

105 James C Scott The art of not being governed (Yale University Press, New Haven, 2009) at 77-79.

${ }^{106}$ Fox and others, above n 2, at 309.
} 
livelihood 'safety net' which enables families to support themselves through commodity price fluctuations. ${ }^{107}$ Rural poverty also enables the persistence of swiddening as many rural households lack the capital needed to move to permanent cultivation. ${ }^{108}$

Demographic drivers are also important. Population growth can occur through inmigration, forced resettlement and natural growth. Increased population is often associated with infrastructure development such as roads ${ }^{109}$ or public services. ${ }^{110}$ However, declines in population can also occur, such as through rural-urban migration, government appropriation of upland areas and conflict. ${ }^{111}$ Swidden farmers both contribute to population trends and respond to them. ${ }^{112}$ Increased population normally causes decreased swiddening as farmers instead begin to use land more intensively such as introducing cash crops as part of their farming system. ${ }^{113}$ However, it may also cause an increased level of swiddening, such as from pioneering swiddeners cultivating new plots in forestland. ${ }^{114}$

Other causal factors noted by writers are socio-cultural, such as changes in education and gender roles. Swiddening reduces as it is perceived as backward, children lose the necessary skills to undertake swidden and they are influenced by global consumerist lifestyles. ${ }^{115}$

Changes in swiddening are often transitional and partial. The primary change is from subsistence agriculture to cash cropping. ${ }^{116}$ Cramb et al describes a process of swiddeners moving from part-time engagement with the market economy (planting cash crops using spare time and resources) to full-time engagement (mainly producing cash crops and planting subsistence crops with surplus resources). ${ }^{117}$ However, there is a tendency for farmers to continue practicing some form of swidden cultivation. ${ }^{118}$ Rambo

\footnotetext{
107 Van Vliet and others, above n 2, at 426; Endah Sulistyawati, Ian R Noble and Michael L Roderick "A simulation model to study land use strategies in swidden agriculture systems" (2005) 85 Agricultural Systems 271 at 271.

${ }^{108}$ Ellen, above n 2, at 33.

${ }^{109}$ Fox and others, above n 2, at 310.

${ }^{110}$ Cramb and others, above $\mathrm{n} 2$, at 326.

${ }^{111}$ Fox and others, above n 2, at 310.

${ }^{112}$ Cramb and others, above $\mathrm{n} 2$, at 325.

113 At 326.

114 Kanok Rerkasem and Benjavan Rerkasem "Montane Mainland South-East Asia: agroecosystems in transition" (1995) 5 Global Environmental Change 313 at 319.

115 Cramb and others, above n 2, at 329.

${ }^{116} \mathrm{Li}$ and others, above $\mathrm{n} 2$, at 1656; Xu, Grumbine and Beckschäfer, above n 3, at 749; Ziegler, Fox and Xu, above $\mathrm{n} 2$.

${ }^{117}$ Cramb and others, above n 2, at 327.

${ }^{118}$ Ellen, above n 2, at 30.
} 
refers to the ongoing integration of swidden cultivation with other forms of agriculture, such as wet-rice cultivation as 'composite' swiddens. ${ }^{119}$ Maintaining swiddening capacity can help communities overcome adverse fluctuations in commodity prices. ${ }^{120}$ For example, if the rate of return for rubber falls below the cost of production, rubber trees can be left untapped. Whereas areas reserved as swidden fallows can be cleared and planted in order to provide subsistence livelihood to families.

Despite predictions of the demise of swiddening, ${ }^{121}$ the practice has persisted into the $21^{\text {st }}$ century. ${ }^{122}$ Moreover, swiddening practices remain dominant in the mountainous areas of mainland South East Asia, such as Myanmar, Laos and Cambodia. ${ }^{123}$ In remote areas, swiddening communities have been more insulated from the change factors mentioned above.

\section{Swidden in Myanmar}

Although there have been studies of particular areas within Myanmar, often relating to forest conservation, ${ }^{124}$ there is a lack of comprehensive research regarding swiddening in Myanmar. ${ }^{125}$ Mertz et al and Schmidt-Vogt et al have given overviews of swidden cultivation in Myanmar from the limited research available. However, statistical accounts

\footnotetext{
${ }^{119}$ A Terry Rambo and others Development trends in Vietnam's northern mountain region (East-West Center, Program on Environment, 1996); Cited in Jefferson Fox and others "Shifting cultivation: a new old paradigm for managing tropical forests" (2000) 50 BioScience 521 at 523.

${ }^{120} \mathrm{Cramb}$ and others, above $\mathrm{n} 2$, at 323; Li and others, above $\mathrm{n} 2$, at 1659-60; Van Vliet and others, above $\mathrm{n}$ 2, at 4; Rubber prices are currently experiencing a dip in prices. Su Phyo Win "Rubber producers optimistic about future despite price freefall" The Myanmar Times (Myanmar, 15 December 2014) $<$ http://www.mmtimes.com/index.php/business/12546-rubber-producers-optimistic-about-future-despiteprice-freefall.html>.

${ }^{121} \mathrm{Li}$ and others, above $\mathrm{n} 2$, at 1659.

${ }^{122}$ At 1660; Schmidt-Vogt and others, above n 1, at 275; Van Vliet and others, above $\mathrm{n} 2$, at 4; Walker, above n 4, at 314; Ellen, above n 2, at 26.

${ }^{123} \mathrm{Li}$ and others, above $\mathrm{n} 2$, at 1660.

${ }^{124}$ Nyein Chan and others "Establishment of allometric models and estimation of biomass recovery of swidden cultivation fallows in mixed deciduous forests of the Bago Mountains, Myanmar" (2013) 304 Forest Ecology and Management 427; U Myint Aung "Policy and practice in Myanmar's protected area system" (2007) 84 Journal of Environmental Management 188; Roy C Sidle, Alan D Ziegler and John B Vogler "Contemporary changes in open water surface area of Lake Inle, Myanmar" (2007) 2 Sustain Sci 55; Win Win Soe "Land and Society: The Changes of Land Utilization and Lifestyle in Waphyudaung Village Tract, Yamethin Township, Myanmar" Universities Research Journal 455; Chenhua Liao and others "The spatiotemporal variation of shifting cultivation in the border region of Myanmar, Laos and Thailand" (2014) 8 地 理研究 13; Yukako Tani "Ecological Factors Affecting Taungya Farmers Behavior in Teak Plantation Projects: A Case Study in Bago Range, Union of Myanmar" (2000) 10 Tropics 273; Akio Takahashi "Swiddens, Rice Terraces, and Malay Connections:Resource Use and Socio-economic Strata in the Chin Hills, Myanmar” (2007) 45 東南アジア研究 404; U San Thein Study on the Evolution of the Farming Systems and Livelihoods Dynamics in Northern Chin State (GRET, 2012).

${ }^{125}$ In Schmidt-Vogt's overview of literature regarding changes in swidden cultivation in Southeast Asia, he did not include any studies from Myanmar. Schmidt-Vogt and others, above n 1, at 272-7.
} 
vary considerably. Population estimates of people practicing swidden are inconclusive and range from 1.5 million to 25 million. ${ }^{126}$ Likewise estimates of the amount of swidden land in Myanmar range from 0.29 to 10.18 million hectares. ${ }^{127}$ Myanmar government statistics estimated that 22.8 per cent of land was affected by swidden cultivation. ${ }^{128}$ Generalised reports maintain that swidden cultivation is continuing in Myanmar's mountainous and outlying areas. ${ }^{129}$

Aung describes swidden cultivation as occurring to a greater or lesser extent in every State and Division, except Yangon Division, in Myanmar. ${ }^{130}$ He notes the areas with the greatest incidence of swidden cultivation are Chin and Shan States. ${ }^{131}$ Win states that large areas of Chin, Kayah, Kayin and Shan States are affected by swidden cultivation. ${ }^{132}$ Literature also highlights specific areas which are affected by swidden cultivation. ${ }^{133}$

Contemporary changes in swiddening in Myanmar are also not uniform in all areas. In some places, such as the Thai-Myanmar border ${ }^{134}$ and Northern Chin State ${ }^{135}$ it appears that the prevalence of swidden is reportedly increasing. However, in others, such as Southern Shan State, Baver et al report that swiddening is becoming very rare. ${ }^{136}$

Writers highlight a range of causative factors. These drivers generally follow those noted above in the context of the wider Southeast Asian region.

(a) Economic factors

In terms of economic factors, writers noted the level of general poverty in areas practicing swidden. ${ }^{137}$ Thein found that farmers could only rely on swidden cultivation to provide food for between three and six months of food and were therefore reliant on other forms of

\footnotetext{
${ }^{126}$ Mertz and others, above n 2, at 284; Win, above n 83, at 7.

${ }^{127}$ Schmidt-Vogt and others, above n 1, at 272; Ellen, above n 2, at 32.

${ }^{128}$ Win, above $\mathrm{n} 83$, at 3 .

${ }^{129}$ Aung, above n 1, at 144; Eberhardt, above n 1; Schmidt-Vogt and others, above n 1, at 272.

${ }^{130}$ Aung, above n 1, at 613-703.

131 At 628 and 694.

132 Win, above $\mathrm{n} 83$, at 5 .

133 Sidle, Ziegler and Vogler, above n 124, at 63; K Eberhardt Farmer Field School for Sustainable Development in MyanmarUpland Project in Sadung and PaO Regions: Report of Mid-term Review (Metta Development Foundation, 2006) at 3; Tom Kramer and others Bouncing Back Relapse in the golden triangle (Transnational Institute); Skidmore and Wilson, above n 8; Takahashi, above n 124, at 404; Thein, above $n$ 124; Liao and others, above n 124; Chan and others, above n 124, at 428; Soe, above n 124, at 458-459.

${ }^{134}$ Liao and others, above n 124.

135 Thein, above n 124 , at 74.

${ }^{136} \mathrm{~J}$ Baver and others Securing Livelihoods and Land Tenure in Rural Myanmar (2013) at 58-59.

${ }^{137}$ Skidmore and Wilson, above n 8, at 279; Thein, above n 124, at 42; Eberhardt, above n 1, at 103-104.
} 
income to support themselves. ${ }^{138}$ Economic hardship means that swiddeners are often unable to obtain sufficient capital to use agricultural technologies for more permanent cultivation. ${ }^{139}$ However, the availability of technology does not always move swidden farmers towards permanent cultivation. Rather, Saumya et al note that increases in technology have made it easier to clear land for swidden, thereby increasing the use of swidden cultivation. ${ }^{140}$

On the other hand, Myanmar's agricultural economy is seen as being in a state of transition. Land is being used more intensively and land use is shifting from subsistence to market-based. ${ }^{141}$ Writers have recognised the increasing commercial interests in Myanmar's uplands in the form of monoculture plantations run by large agribusiness companies. ${ }^{142}$ Rubber, eucalyptus, oak and oil palm plantations have rapidly expanded into mountainous areas. ${ }^{143}$ Recent studies have shown extensive growth in rubber plantations in Northern Myanmar. ${ }^{144}$ It appears that these trends will continue ${ }^{145}$ as the Myanmar government aims to expand the area producing rubber by a further 80,000 hectares by 2030 . 146

The increase in monoculture plantations has also added land scarcity issues and conflict between small holders and large agricultural businesses. ${ }^{147}$ Various writers noted the lack of land available for cultivation. ${ }^{148}$ This has reportedly led to less viable land being

\footnotetext{
${ }^{138}$ Myat Thein "The Economics of Farm Size and Land Policy in the Transition to a Market Economy" (1997) 12 Sojourn: Journal of Social Issues in Southeast Asia 124 at 3.

139 Thein, above n 124, at 42; Skidmore and Wilson, above n 8, at 279; Aung, above n 1, at 629.

140 Nilmini Senavirathna Saumya, Wityi Hnin and Fujino Takeshi "Community knowledge and attitude towards regional developmental requirements in remote townships of Chin state, Myanmar" (2014) 2014 International Journal of Human Culture Studies 25 at 28.

${ }^{141}$ Eberhardt, above n 1, at 103-104; Win, above n 83, at 11.

${ }^{142}$ Eberhardt, above n 1, at 103-104 and 108; Baver and others, above n 136, at 72.

${ }^{143} \mathrm{Li}$ and others, above $\mathrm{n}$ 2, at 1672; Fox and Castella, above n 3; Liu and others, above n 3; Li and Fox, above n 3; Xu, Grumbine and Beckschäfer, above n 3; Ziegler, Fox and Xu, above n 2; Woods, above n 3; Fox, Castella and Ziegler, above $\mathrm{n} 3$.

${ }^{144} \mathrm{Li}$ and Fox, above n 3; For example in 1990 , there was $2 \mathrm{~km}^{2}$ of rubber plantations in Northern Myanmar. By 2000 , that had increased to $33 \mathrm{~km}^{2}$. However, in 2010 , that figure had jumped to $607 \mathrm{~km}^{2}$. Liu and others, above $\mathrm{n} 3$, at 1029 .

${ }^{145}$ Liu and others, above $\mathrm{n} 3$, at 1030.

${ }^{146}$ OECD OECD Investment Policy Reviews (Organisation for Economic Co-operation and Development, Paris, 2014) at 304.

${ }^{147}$ Steven Haggblade and others A Strategic Agricultural Sector and Food Security Diagnostic for Myanmar (USAID, MSU and MDRI/CESD, 2013) at 23; Eberhardt, above n 1, at 103-104.

${ }^{148}$ Hudson-Rodd and others, above n 9, at 9; Sai Latt and Robin Roth "Agrarian Change and Ethnic Politics: Restructuring of Hmong and Shan Labour and Agricultural Production in Northern Thailand" [2014] Journal of Agrarian Change at 195; Saumya, Hnin and Takeshi, above n 140, at 28; Thein, above n 124, at 42; Eberhardt, above n 1, at 103-104.
} 
used for swiddens, ${ }^{149}$ encroachment onto reserved forest land ${ }^{150}$ and shorter fallow periods. ${ }^{151}$ Despite growth in large agribusiness companies, there is still a lack of infrastructure in many hill-country areas, such as roads connecting to markets and other rural based industries. ${ }^{152}$ In mountainous areas isolated from infrastructure and markets, with small populations and less state control, swidden remains the dominant land use. ${ }^{153}$

Another complicating economic factor is illicit drugs. Opium cultivation was introduced to Northern and North-eastern Myanmar in the late $19^{\text {th }}$ century. ${ }^{154}$ Local farmers integrated opium production into swidden practices. ${ }^{155}$ Since then, opium has been a valuable, important and politically charged commodity in the border regions of Myanmar. ${ }^{156}$

Swiddeners have moved to cultivating opium in their swidden fallows as, in very remote areas affected by severe erosion and poor soil quality, opium poppies are one of the few economically viable crops. ${ }^{157}$ Despite growers receiving relatively little remuneration for cultivating and harvesting opium, ${ }^{158}$ returns are higher than alternative crops, credit is easier to obtain and the grower is not required to transport produce to local markets. ${ }^{159}$

Myanmar and its surrounding countries have responded in various ways to the increase in opium production. Since the 1960s, China and Thailand have implemented policies in order to eradicate opium production from border areas. ${ }^{160}$ The Chinese

\footnotetext{
${ }^{149}$ Hudson-Rodd and others, above $\mathrm{n}$ 9, at 9.

${ }^{150}$ Myat Su Mon and others "Factors affecting deforestation and forest degradation in selectively logged production forest: A case study in Myanmar” (2012) 267 Forest Ecology and Management 190 at 195.

${ }^{151}$ Saumya, Hnin and Takeshi, above n 140, at 28; Eberhardt, above n 1, at 108; Win, above n 83, at 9.

152 Thein, above n 124, at 42.

153 Mertz and others, above n 2, at 284; Peter Leimgruber and others "Forest cover change patterns in Myanmar (Burma) 1990-2000” (2005) 32 Environmental Conservation 356 at 361.

${ }^{154}$ Lintner, above n 7, at 60; Janet C Sturgeon "Border Practices, Boundaries, and the Control of Resource Access: A Case from China, Thailand and Burma” (2004) 35 Development and Change 463.

${ }^{155}$ Elson, above n 6, at 110-111.

156 See Lintner for a detailed account of the role of opium in Myanmar's politics from 1948-1997 Lintner, above n 7; UNODC Southeast Asia Opium Survey 2014: Lao PDR, Myanmar (UNODC Regional Office for Southeast Asia and the Pacific, 2014) at 49; Baver and others, above n 136, at 22; Kramer and others, above n 133; OECD, above n 146, at 304-305.

${ }^{157}$ Hudson-Rodd and others, above $\mathrm{n} 9$, at 9.

${ }^{158}$ Lintner, above n 7, at 236.

${ }^{159}$ Kramer and others, above n 133, at 13-14.

${ }^{160}$ Fox and others, above n 2, at 311; Derek Byerlee "The Fall and Rise Again of Plantations in Tropical Asia: History Repeated?" (2014) 3 Land 574 at 589; Such as the Chinese Opium substitution programme. Lintner, above n 7; Martin Jelsma and others Trouble in the triangle (Silkworm Books, 2005); Tom Kramer and Kevin Woods Financing Dispossession - China's Opium Substitution Programme in Northern Burma (Transnational Institute, 2012).
} 
government has provided various incentives to encourage Chinese businesses to convert opium-producing swidden fields into plantations. ${ }^{161}$ Liu highlights the link between opium substitution programmes and the growth in rubber plantations Northern Myanmar. ${ }^{162}$

Myanmar has also formed opium replacement policies, such as to continue encouraging upland terracing in order to eliminate opium cultivation. ${ }^{163}$ Opium cultivation bans have been strictly enforced by cease-fire groups in areas of Myanmar. ${ }^{164}$ Where opium has been banned, land is put under severe stress and farmed unsustainably as underlying poverty and food security issues have not been addressed. ${ }^{165}$ The UNODC highlighted the lack of suitable land resources available for food production as one of the most powerful drivers towards opium production. ${ }^{166}$ Economic hardship follow opium bans forces many farmers to move to areas where opium poppies can still be grown. ${ }^{167}$

The cultivation of opium in Myanmar was recognised as reducing up until $2006{ }^{168}$ and former opium producing swiddens were being used for other crops. ${ }^{169}$ However, since 2006, poppy cultivation has increased steadily. ${ }^{170}$ Opium production continues to persist in "peripheral, difficult-to-access locations, far from population and market centres." 171

(b) Demographic factors

Demographic factors are also mixed. Areas where swidden was practiced generally have low population densities. ${ }^{172}$ However, various factors influence the population distribution. For example, social pressures cause families to relocate in order to live more closely to schools and government services. ${ }^{173}$ This reduces the population in the areas they have left from, which affects the viability of swidden cultivation through reducing available labour

\footnotetext{
${ }^{161}$ OECD, above n 146, at 304-305, 323.

${ }^{162}$ Liu and others, above n 3 , at 1021.

163 Kan Zaw and others "Agricultural Transformations, Institutional Changes and Rural Development in Ayeyarwady Delta, Myanmar" in PS Intal, S Oum and MJO Simorangkir (eds) Agricultural Development, Trade and Regional Cooperation in Developing East Asia (ERIA, Jakarta, 2011) at 324-325.

${ }^{164}$ Kramer and others, above n 133, at 13.

${ }^{165}$ Food Security Working Group, above n 41, at 15; Kramer and others, above n 133, at 13.

${ }^{166}$ Kramer and others, above n 133, at 16.

${ }^{167}$ Skidmore and Wilson, above n 8, at 69-70.

168 Eberhardt, above n 1.

${ }^{169}$ Eberhardt, above n 133, at 23.

${ }^{170}$ Kramer and others, above n 133.

${ }^{171}$ UNODC, above n 156, at 17.

172 Thein, above n 138, at 42.

${ }^{173}$ Baver and others, above n 136, at 72.
} 
for clearing and burning land to plant. On the other hand, it also increases the population of areas where they settle. Population growth results in shortened fallow periods in swidden plots ${ }^{174}$ and issues of landlessness. ${ }^{175}$

(c) Political factors

Relevant political factors affecting swidden cultivation include intervention by the government and NGOs. They have encouraged changes from swidden cultivation, to more permanent forms, such as upland terraced cultivation systems. ${ }^{176}$ The Burmese government has also sought to attract foreign capital and technological investment through various tax incentives. ${ }^{177} \mathrm{Up}$ to the present, investors from China, Thailand, Vietnam and Malaysia have invested heavily in agriculture the region. ${ }^{178}$ The establishment of the China-ASEAN free trade area in 2010 has been another significant catalyst to foreign investment in Myanmar. ${ }^{179}$ Lawlessness ${ }^{180}$ and the lack of land tenure recognition ${ }^{181}$ has had mixed effects on swidden. It dis-incentivises investment in land resources as there is little legal protection to prohibit these resources being appropriated. However, it also encourages large agribusiness plantations which are able to secure land irrespective of underlying land claims. ${ }^{182}$ As the country attracts further foreign investment, fallow swidden land continues to be vulnerable to re-allocation. ${ }^{183}$

The political, economic, demographic and socio-cultural factors influencing swidden land use form the environment surrounding and incorporated in the mechanisms enabling access to swidden land. In Myanmar, this milieu is complex, multifaceted and is in a process of continual flux.

\footnotetext{
174 Thein, above n 138, at 3; Skidmore and Wilson, above n 8, at 279; Eberhardt, above n 1, at 103-104; Win, above $\mathrm{n} 83$, at 9 .

175 Baver and others, above n 136, at 59.

176 Thein, above n 138, at 20, 37ff.

${ }^{177}$ Fox and Castella, above n 3, at 165.

${ }^{178} \mathrm{Xu}$, Grumbine and Beckschäfer, above n 3, at 752; Fox and Castella, above n 3, at 159; Woods, above n 3, at 3; Liu and others, above n 3, at 1028-9.

${ }^{179}$ Liu and others, above n 3, at 1030.

180 Eberhardt, above n 1, at 108.

${ }^{181}$ Skidmore and Wilson, above n 8, at 279.

182 Baver and others, above n 136, at 75; Giles Henley Case study on land in Burma (Overseas Development Institute (ODI), 2014) at 10.

183 OECD Multi-dimensional Review of Myanmar (Organisation for Economic Co-operation and Development, Paris, 2013) at 293.
} 


\section{Customary Land Management (CLM) systems}

The mechanisms of access which have predominantly regulated access to swidden land are CLM systems. ${ }^{184}$ Ørebech et al define customary law as "a popular normative pattern that reflects the common understandings of valid, compulsory rights and obligations." 185 Rights and obligations controlling the use of land resources form CLM systems. They are founded on relational and social factors, such as status and social standing within a community. ${ }^{186}$ Multiple rights and obligations may simultaneously coexist over an area of land. ${ }^{187}$ They can also include obligations to ancestors and future generations ${ }^{188}$ as well as incorporating spirituality into their conceptions of customary land tenure. ${ }^{189}$

\section{Customary Land Management (CLM) systems in Myanmar}

CLM systems in Myanmar are diverse, complex, localised and adaptable. ${ }^{190}$ Prior to British colonisation, forest and land resources in Myanmar's outer regions were governed by customary law. ${ }^{191}$ Land was managed collectively under the direction of local traditional leadership. ${ }^{192}$ Each plot was collectively felled, cleared and burned before it was divided into individual sub-plots. These subplots were individually cultivated and

\footnotetext{
${ }^{184}$ Colfer et al outline various CLM systems from around the world which control swidden. Cairns, above $\mathrm{n}$ 72, at 71-73; Joseph Earle Spencer Shifting Cultivation in Southeastern Asia (University of California Press, 1966) at 25.

${ }^{185}$ Ørebech et al also note contentions over definitions of customary law in terms of when a custom becomes customary law. See Ørebech and others, above n 13, at 16.

${ }^{186}$ Camilla Toulmin, Philippe Lavigne Delville and Samba Traoré The dynamics of resource tenure in West Africa (GRET ; IIED, Paris : London, 2002) at 10.

${ }^{187}$ Lee Godden and Maureen Tehan Comparative perspectives on communal lands and individual ownership (Routledge, Abingdon, Oxon, England; New York, NY, 2010) at 266; Citing Kristine Juul, Christian Lund and others Negotiating property in Africa (Heinemann, 2002) at 17.

${ }^{188}$ Cleary and Eaton, above n 40, at 47.

189 Toulmin, Lavigne Delville and Traoré, above n 186, at 10; Raymond L Bryant The political ecology of forestry in Burma, 1824-1994 (University of Hawai'i Press, Honolulu, 1997) at 67; Janet Carol Sturgeon "Practices on the Periphery: Marginality, Border Powers, and Land Use in China and Thailand" (Candidacy for the Degree of Doctor of Forestry and Environmental Studies, Yale University, 2000) at 167-177; Burmese Border Consortium (Thailand) Reclaiming the right to rice (Burmese Border Consortium, 2003) at 37-38; Thein, above n 124, at 15.

${ }^{190}$ Food Security Working Group, above n 41, at v.

${ }^{191}$ HNC Stevenson The Economics of the Central Chin Tribes (Greg Press Limited, England, 1968) at ch XI; Kirk Talbott, John Waugh and Douglas Batson "A US Asian-Pacific Pivot Point: Burma's Natural Resources" (2013) 4 Prism : a Journal of the Center for Complex Operations 110 at 112-3.

192 Talbott, Waugh and Batson, above n 191, at 112-3.
} 
produce was not shared communally. ${ }^{193}$ Colonial writers such as Furnivall, ${ }^{194}$ BadenPowell ${ }^{195}$ and Nisbet ${ }^{196}$ also provide insight into pre-colonial CLM practices.

Generally, customary land rights were established through first clearance of forested land and could also be relinquished through abandonment. ${ }^{197}$ This is similar to traditional agricultural practices throughout Southeast Asia. ${ }^{198}$ In Myanmar the principle of right of first clearance is called dama-ugya. ${ }^{199}$ Furnivall detailed this process further. ${ }^{200}$ Villagers could clear land over which their village had some territorial connection if there were no existing claims to the land. However, explicit or implicit consent could be given by previous right-holders to use the land. ${ }^{201}$ For example, if dama-ugya land was left vacant for 12 years, it was implicitly free for another to clear. ${ }^{202}$ Dama-ugya land was able to be mortgaged, sold or bequeathed to descendants. ${ }^{203}$ Once this land was inherited, it was then classified as bobabaing. ${ }^{204}$ Furnivall caveated that this type of tenure did not equate to absolute free-hold possession. Rather, the surrounding community could use cultivated land to build houses or a monastery. Likewise, while bobabaing land was alienable, it could be redeemed by family members for up to seven generations. ${ }^{205}$

For more specific examples of CLM systems, Stevenson described land tenure

${ }^{193}$ Edmund Ronald Leach Political systems of highland Burma (Athlone Press, London ; Atlantic Highlands, NJ, 1986) at 116; Throughout Southeast Asia swidden land is held in a mix of communal and individual tenure. Robin Roth "The challenges of mapping complex indigenous spatiality: from abstract space to dwelling space" (2009) 16 Cultural Geographies 207 at 214.

194 John Sydenham Furnivall Colonial policy and practice (CUP Archive, 1956); John Sydenham Furnivall An introduction to the political economy of Burma (Peoples' Literature Committee \& House, 1957).

195 Baden-Powell, above n 6.

196 John Nisbet Burma under British rule - and before (Archibald Constable, Westminster, 1901) vol 1; John Nisbet Burma under British rule - and before (Archibald Constable, Westminster, 1901) vol 2.

${ }^{197}$ Furnivall, above n 194, at 109-110; Stevenson, above n 191, at 86.

198 Baden-Powell, above n 6, at 493; Elson, above n 6, at 129.

199 The principle of obtaining land use rights on first clearance of land is called dama-ugya (also dama-ucha or dama-u-kya). It literally means "the one who wields the machete". Nisbet, above n 196, at 165-167; Baver and others, above n 136, at 15; Land Core Group of the Food Security Working Group, above n 83, at 1415.

${ }^{200}$ Furnivall, above n 194, at 109-110.

201 Win, above $\mathrm{n} 83$, at 8 .

202 Furnivall, above n 194, at 109.

${ }^{203}$ Furnivall, above n 194, at 50; Nisbet, above n 196, at 167.

${ }^{204}$ Also known as "bo-ba-baing" which means "owned by the father and grandfather" Nisbet, above n 196, at 165-7; Win transliterates the Burmese as "bo bwapaing". Win, above n 83, at 32.

${ }^{205}$ Furnivall, above n 194, at 109-110. 
systems within the Chin tribes of Myanmar ${ }^{206}$ and Leach, for Kachin tribes. ${ }^{207}$ The right of first clearance also existed and could continue for a long period of time after cultivation ceased. ${ }^{208}$ If an unrelated group cleared the forest again, they could be required to pay a token rent to 'use' the land. ${ }^{209}$

Village leadership held greater land rights than those in the rest of the village. Leadership rights and responsibilities were vested in a chief or headman, ${ }^{210}$ delegated to a lower tier of leadership ${ }^{211}$ or collectively managed by a village council. ${ }^{212}$ Leach described leaders as having political sovereignty over the land and that villagers were able to obtain usufruct rights in land. ${ }^{213}$ There were also restrictions in how chiefly rights in land could be transferred or inherited. ${ }^{214}$

Membership of the village community provided villagers with rights of access to gather forest products, such as dried timber, thatch and wild fruit as well as hunting, fishing. It also gave rights of way for herds to be watered and graze in areas which are not currently cultivated. Before cultivating land, a household had to pay a nominal amount to the chief. 215 The payment was not considered 'rent', rather, it enabled land to be divided into plots used for cultivation. 216

Land was communally felled, burned and fenced, before individual plots were allocated and cultivated. The length of time spent cultivating one plot would be determined by the type of crop and the quality of the soil. The number and size of plots would be determined by land availability and population size. Sub-plots could be allocated either by a lottery system or by inheritance. ${ }^{217}$ The household then had the right to the crops grown on their particular plot of land along with prior claim to thatch. ${ }^{218}$ Crops were individually

\footnotetext{
206 Stevenson, above n 191, at 81 and 89; See also Sakhong for details about pre-colonial CLM systems in Chin State. Lian H Sakhong and Nordic Institute of Asian Studies In search of Chin identity (NIAS Press, Copenhagen S, Denmark, 2003) at 35-42.

${ }^{207}$ Ma Khin Mya "The Impact of Traditional Culture and Environmental Forces on the Development of the Kachins, a Sub-cultural Group of Burma” (University of Maryland, College Park, 1961).

${ }^{208}$ Leach, above n 193, at 115.

209 At 155.

${ }^{210}$ Stevenson, above n 191, at 81; Leach, above n 193, at 155.

211 Stevenson, above n 191, at 83.

212 At 84 and 89-90; Win, above n 83, at 8.

${ }^{213}$ Leach, above n 193, at 155; Stevenson, above n 191, at 82.

${ }^{214}$ Leach, above n 193, at 156-157; Stevenson, above n 191, at 80-81.

215 Stevenson, above n 191, at 87.

${ }^{216}$ Mya, above n 207, at 64.

${ }^{217}$ Food Security Working Group, above n 41, at 18.

218 Stevenson, above n 191, at 87.
} 
grown and are not shared communally. They also had the sole right to wild fruit which grows on the plot during cultivation. These principles are the same for swiddening on grassland as in forested areas. ${ }^{219}$ Both Chin and Kachin CLM systems are strongly patrilineal. Land rights are passed either through the eldest or youngest son depending on tradition. 220

In some areas, land could be rented or even sold. These developments occurred in areas where there was population growth and intensification of land use. ${ }^{221}$ However, normally transactions would only occur between households belonging to the same village 222

\section{Changes in CLM}

CLM systems are reportedly found throughout the Southeast Asian region, particularly in hill-tribe communities. ${ }^{223}$ Various factors have influenced how CLM systems function. However, there is little information about how CLM systems currently operate, ${ }^{224}$ let alone the factors driving any changes. Writers discussing the changes in swidden cultivation in Southeast Asia have noted changes in CLM systems as part of this transition. ${ }^{225}$ However, there is a lack of research isolated to the drivers of change in CLM systems in the wider Southeast Asian region. The factors influencing these changes closely resemble those outlined above in chapter four which affect changes in swidden cultivation. ${ }^{226}$ In relation to Myanmar, the Food Security Working Group reports factors which have significantly influenced CLM systems as population growth, resettlement and migration (demographic), market integration (economic) and the creation of forest reserves (political). ${ }^{227}$ In areas least affected by these change factors, CLM is widespread. ${ }^{228}$

Writers have distinguished different types of swidden cultivation by the strength of its connection to an established CLM system. Conklin categorised some swidden systems as 'partial' and others as 'integral.' ${ }^{229}$ Integral swiddening systems have been defined as a

\footnotetext{
${ }^{219}$ Leach, above n 193, at 116.

${ }^{220}$ Food Security Working Group, above n 41, at 17-18; Stevenson, above n 191, at 86; Leach, above n 193, at 157; Woods, above n 3, at 11-12.

${ }^{221}$ Baden-Powell, above $\mathrm{n}$ 6, at 507.

222 Stevenson, above n 191, at 91-2; Sakhong and Nordic Institute of Asian Studies, above n 206, at 35-42.

${ }^{223}$ Cleary and Eaton, above n 40, at 49.

${ }^{224}$ Food Security Working Group, above n 41, at 17.

${ }^{225}$ Fox and others, above n 2, at 314.

${ }^{226}$ Lorenzo Cotula Changes in Customary Land Tenure Systems in Africa (IIED, 2007) at 12-31.

${ }^{227}$ Food Security Working Group, above n 41, at 21.

228 At 18.

${ }^{229}$ Ellen, above n 2, at 20.
} 
"traditional, year-round, community-wide, largely self-contained and ritually-sanctioned way of life." 230 These swiddening systems are more closely aligned with and regulated by CLM systems as they rely on more traditional, cohesive and stable social structures and processes. ${ }^{231}$ However, partial systems are more detached from CLM systems and view swidden cultivation simply as a means to produce food. ${ }^{232}$ This category includes new arrivals into an area that clear, burn and cultivate land for short term economic gain, rather than long-term communal sustainability. ${ }^{233}$ It also includes households which are moving away from traditional subsistence swidden cultivation into a mix of permanent and swidden. ${ }^{234}$ Traditional customary law systems governing the use of swidden agriculture are stronger in more integral systems and weaker in more partial systems. ${ }^{235}$

However, these change factors do not necessarily lead to the disintegration of CLM systems. Rather, in many situations, CLM systems are able to adapt to changes in circumstances. For example if population increased and land availability decreased, the system is able to adapt by establishing more plots or re-dividing them between the village households. In areas where there is a higher population density, a more individualised land system has formed along with a land rental market. ${ }^{236}$

Even in areas where there has been a considerable amount of conflict and displacement, there is continued reliance on customary land rights. In surveys conducted by non-governmental agencies along the Myanmar-Thailand border, 71 per cent of respondents claimed that their authority to use agricultural land was derived from the authority of village leaders and/or customary land rights. ${ }^{237}$ However, CLM systems are noted as weaker in areas where swiddeners are new arrivals in an area. ${ }^{238}$

\footnotetext{
${ }^{230}$ Harold C Conklin and others "Hanunoo agriculture A report on an integral system of shifting cultivation in the Philippines Vol 2" [1957] For Devel Pap 12 FAO; Cited in Spencer, above n 184, at 23.

${ }^{231}$ Food Security Working Group, above n 41, at 15.

232 Spencer, above n 184, at 23.

233 Also called "incipient" swidden farmers. At 23; Food Security Working Group, above n 41, at 15; Mertz et al discuss the various categories of swidden farming and conclude that contemporary systems are in such a state of dynamic flux, it is difficult to classify them simply. Mertz and others, above n 69, at 261.

${ }^{234}$ Also called "supplementary" swidden farming. Spencer, above n 184, at 23; Or "composite" swiddening A Terry Rambo "The composite swiddening agroecosystem of the Tay ethnic minority of the northwestern mountains of Vietnam" [1998] Land Degradation and Agricultural Sustainability: Case Studies from Southeast and East Asia, Regional Secretariat, The Southeast Asian Universities Agroecosystem Network (SUAN) Khon Kaen University, Khon Kaen 43.

235 Cleary and Eaton, above n 40, at 48.

${ }^{236}$ For example, in Chin State. Food Security Working Group, above n 41, at 19.

237 Thailand Burma Border Consortium Internal displacement and protection in Eastern Burma (Thailand Burma Border Consortium, 2005) at 45; Food Security Working Group, above n 41, at 21.

${ }^{238}$ Food Security Working Group, above n 41, at 15; Eberhardt, above n 1, at 103.
} 
CLM systems appear adaptable to changing circumstances. However, rapid changes seem to strain their resilience. ${ }^{239}$ Changes to CLM systems brought about by their interaction with the SLM system will be discussed further in chapter seven.

${ }^{239}$ Fox and others, above n 2, at 314. 


\section{$V$ The State Land Management (SLM) system in Myanmar}

The State Land Management (SLM) system in a country is a mechanism of access to land resources which are authorised and managed by the State. ${ }^{240}$ SLM systems rely on formal, law-based property rights and enforcement mechanisms, in order to enable actors to use and benefit from land. ${ }^{241}$ The SLM system is influenced by many factors which shift over time. ${ }^{242}$ The SLM system in Myanmar has changed significantly over the past 200 years as the country has experienced periods of political, economic and social change.

\section{$1 \quad$ Pre-colonial}

In pre-colonial times, Myanmar was governed by various dynasties of Burmese Kings based in Upper Burma. ${ }^{243}$ Taylor discusses the nature of the pre-colonial state as forming a series of concentric zones extending from its centre. As these zones moved away from the centrally administered state, its power diminished. Localised hereditary rulers governed these areas and maintained allegiances with the state. ${ }^{244}$ The sources of law under these dynasties were customary Burmese legal texts ${ }^{245}$ and royal decrees. ${ }^{246}$

The monarch claimed 'Lordship of Land and Water' 247 and maintained that his decrees would prevail over customary law in matters regarding property. ${ }^{248}$ Scholarship with

240 The State can defined as "an organization which controls the population occupying a defined territory...[that is]... differentiated from other organizations operating in the same territory;... autonomous;... centralized; ... its divisions are formally coordinated with one another" and it determines its relationship with other groups and institutions as well as the relationships of groups and institutions with each other. Taylor, above $\mathrm{n}$ 7, at 9-10.

${ }^{241}$ Edella Schlager and Elinor Ostrom "Property-Rights Regimes and Natural Resources: A Conceptual Analysis" (1992) 68 Land Economics 249 at 254; Vandergeest and Peluso, above n 65, at 386.

${ }^{242}$ Andrzej Rapaczynski "The roles of the state and the market in establishing property rights" [1996] The Journal of Economic Perspectives 87 at 87; Ribot and Peluso, above n 35, at 154 and 162.

${ }^{243}$ For a detailed history of the Burmese dynasties, see Godfrey Eric Harvey History of Burma from the Earliest Times to 10 March 1824 (Octagon Books, 1967).

${ }^{244}$ Taylor, above $\mathrm{n}$ 7, at 23; Nisbet, above n 196, at 169-170.

${ }^{245}$ Called Dhammathat, Dammathat or Dhammasat. Andrew Huxley "The Importance of the Dhammathats in Burmese Law and Culture" (1997) 1 Journal of Burma Studies 1; Dr E Maung Expansion of Burmese law (Cornell University Press, 1951); Kinwun Mingyi U Gaung A Digest of the Burmese Buddhist Law (1893); Htin Aung Burmese Law Tales (Oxford University Press, 1962) at 9.

${ }^{246}$ Rajathat (compiled decisions of the King) and pyatton (orders of the King). Andrew Huxley "Rajadhamma confronts Leviathan: Burmese political theoryin the 1870s" in Ian Harris (ed) Buddhism, Power and Political Order (Routledge, Oxon (England), 2007) 26 at 26.

${ }^{247}$ Andrew Huxley "Buddhism and Law-The View From Mandalay" (1995) 18 Journal of the International Association of Buddhist Studies 47 at 77; Toe Hla "Money-lending and contractual thet-kayits: A socioeconomicpattern of the later Kon-baung period, 1819-1885" at 22.

${ }^{248}$ Huxley, above n 247, at 75; For further information about the development of Burmese pre-colonial law see, Maung, above n 245; Maung Maung and others Law and custom in Burma and the Burmese family (Springer, 1963); Aung, above n 245; Hla Aung "Burmese Concept of Law" (1969) 52 Journal of the Burma Research Society 27. 
regard to Myanmar's pre-colonial state land tenure systems has been primarily focused on the system in Upper Burma before it was annexed by the British and the monarchy destroyed in 1886. ${ }^{249}$ The system was very complex. However, in general, the king possessed inherent title to the land and people retained a nominal right to hold land. These usage rights could be bought, sold, mortgaged and inherited. The king required the people to give a certain amount of produce as form of rent for using the land. ${ }^{250}$ The term of the cultivators' tenancy was at the discretion of the king and ranged from frequent eviction to long-term tenure. ${ }^{251}$ Despite his power, the king was still accountable to the law. ${ }^{252}$ The king controlled land sales in order to ensure that no land owner in an outer area consolidated large amounts of land and became another economically powerful city. 253

Land was divided into different categories, namely, state land, religious land and private land. ${ }^{254}$ State land was used to support the central economy and allocated to various officials in order to exercise political and administrative control. ${ }^{255}$ Private land could be acquired in 3 different ways: either by the right of first clearance of wasteland, a grant by the King or by purchasing it. ${ }^{256}$ Land rights in more outlying areas, such as Southern Myanmar were haphazardly recorded. ${ }^{257}$

\section{Colonial period (1825-1948)}

The British Empire strengthened its control of different areas of Myanmar from 1825 until it annexed Upper Burma in 1886. After the Burmese monarchy was defeated in the third Anglo-Burmese war, the British claimed sovereignty by means of conquest. ${ }^{258}$ Burma was subsumed as part of British India within the British Empire. The British remained in control

\footnotetext{
${ }^{249}$ For example, see Furnivall, above n 194; Nisbet, above n 196; Baden-Powell, above n 6; Thant Myint-U, above n 7; Hla, above n 247.

${ }^{250}$ Hla, above n 247, at 55; Taylor, above n 7, at 40-43; Nisbet, above n 196, at 166.

251 Taylor, above n 7, at 40-3.

${ }^{252}$ After about the 13th Century, the King presided over a panel of judges. This Supreme Court was called the Hluttaw. However, the king himself could be sued under the jurisdiction of the court. For example, in 1810 King Bodawpaya was sued for wrongful seizure of land. Aung, above n 245, at 7.

253 Ardeth Maung Thawnghmung Behind the teak curtain (Kegan Paul Limited, London; New York, 2004) at 19; Taylor, above $\mathrm{n} 7$, at 43 .

${ }^{254}$ Hla, above n 247, at 55-57; Nisbet, above n 196, at 165-166.

255 Hla, above n 247, at 56.

${ }^{256}$ As in CLM systems, this land was named "bobabaing". At 57-58.

257 Taylor, above n 7, at 41 .

${ }^{258}$ Bryant, above n 189, at 59.
} 
of Burma until it was granted independence in 1948. ${ }^{259}$

The British colonial administration overhauled Burma's legal and political system. They introduced modern state administration including a civil service, reporting structures, an independent judiciary and a legislature which produced black-letter law. ${ }^{260}$ The legislature super-imposed statutes from Colonial India, which codified British common law, onto Burma's existing legal system. ${ }^{261}$

The main goals of the Colonial State were to maintain political stability as cheaply as possible and enable the generation of wealth within the country. ${ }^{262}$

(a) Control

Ultimately, colonial rule was backed by imperial military force. ${ }^{263}$ However, there were regional differences to how legislative and governance changes were implemented. Hill country areas were demarcated from the lowlands. In lowland areas, the British adopted a more interventionist approach. They appointed headmen over various geographical regions and altered their traditional roles. ${ }^{264}$ However, for hill-country areas, the British used indirect control methods. Because little revenue could be raised from these areas, it only justified minimal expenditure on administration. They did not prepare precise maps of these areas either. The British therefore preserved the power of the local chiefs and barely changed their responsibilities. ${ }^{265}$

(b) Wealth-generation

The British introduced a capitalist economic model in Burma. Land resources were viewed through utilitarian and rationalistic perspectives. Land was a means to satisfy the domestic demand for food and other natural resources. Surplus resources could be exported generating further wealth. It also provided the foundation for taxation in the form of land revenue. 266

They introduced laws to collect land taxes. The Lower Burma Land and Revenue Act 1876 enabled individuals to gain title to wastelands which they occupied and paid taxes

\footnotetext{
259 Taylor, above n 7, at 229; Although British rule was interrupted by Japanese occupation during WWII from 1942 to 1945 . At 223 and 232.

${ }^{260}$ Furnivall, above n 194, at $\mathrm{r}-\mathrm{s}$.

261 Scott Leckie and Ezekiel Simperingham Housing, land, and property rights in Burma (Displacement solutions : HLP Institute, Geneva, Switzerland, 2009) at 20.

262 Taylor, above $\mathrm{n} 7$, at 150 .

263 At 101-102.

${ }^{264}$ At 80-81.

${ }^{265}$ At 80-81, 88-89.

266 At 89-92.
} 
on for 12 years. ${ }^{267}$ Families from Upper Burma moved down to Lower Burma in order to clear stretches of swamp and jungle for cultivation. This land could be used as collateral and would be transferred to the lender on creditor default and foreclosure. ${ }^{268}$ The Upper Burma Land and Revenue Regulation 1889 extended the taxation system from the delta region into Upper Burma after it was annexed by Britain. ${ }^{269}$

The British also introduced various administrative land categories for taxation purposes. In general, agricultural land was taxed and non-agricultural land was either nominally taxed or exempt from taxation. ${ }^{270}$ Many of these categories have continued in the contemporary SLM system.

3 Independence (1948-1962), Revolutionary Council (1962-1974) and BSPP Control (1974-1988)

(a) Independence (1948-1962)

Independence from the British Empire in Burma was marked by a move towards socialist, nationalistic and reformist government. Some of the changes in the SLM system were maintained until the economic reforms of the 1980s, others continue to the present day.

During the 1920s, British Burma enjoyed the economic benefits of the capitalist economic system which had been introduced. Widespread conversion of land in Lower Burma into cultivable wet rice farms since the mid- $19^{\text {th }}$ Century led to Burma becoming the leading exporter of rice in the world. ${ }^{271}$ They also increased their supply of teak to international markets and established systems to more sustainably manage forestry assets. 272

However, the negative results of this model were also highlighted in 1930s. Burmese rice cultivators were vulnerable to commodity price fluctuations. The 1930s depression caused the world price for rice to plummet. Many rice producers were heavily indebted and were unable to service their commercial loans. Money-lenders foreclosed on agricultural land resulting in a large population of landless Burmese. Nearly half of the agricultural land in Burma's delta region was owned by non-agriculturalists, such as Indian Chettiar moneylenders. ${ }^{273}$

The new government thought that the removal of freehold ownership of land along

\footnotetext{
${ }^{267}$ Furnivall, above n 194, at 50.

${ }^{268}$ Brown, above n 7, at 37.

${ }^{269}$ Food Security Working Group, above n 41, at 26.

${ }^{270}$ At 25; Section 4, Lower Burma Land Revenue Act 1876. Leckie and Simperingham, above n 261.

${ }^{271}$ Brown, above $\mathrm{n} 7$.

272 Bryant, above n 189; Bryant, above n 81.

${ }^{273}$ Elson, above n 6, at 134-5; Brown, above n 7, at 8 .
} 
with State acquisition and redistribution of assets would help address these issues. It aimed to rid Burma of European and Indian influence ${ }^{274}$ and establish indigenous, more egalitarian control of natural resources. These policies established the foundation for greater government control of land through regulation and intervention.

The greatest changes to the SLM system were land tenure reforms restricting land markets, nationalisation of assets and the centralised control of agricultural production.

(b) Land tenure reforms

The 1947 Constitution, drafted prior to gaining independence, reflected the contemporary political climate. It enshrined the state as the "ultimate owner of all lands." 275 The government then passed the Land Nationalisation Act 1953 which implemented the agricultural policy direction set by the constitution. Together, these documents attempted to redress the existing inequalities in resource distribution caused by colonial capitalism. They undermined the rights of landlords to agricultural land. They also set the trajectory that the SLM system would follow over the next 40 years.

The Nationalisation Act 1953 abolished private land ownership and instead recognised usufruct land use rights, or 'tillage rights' to those currently working the land. 276 This was achieved through the State taking possession of all agricultural land, unless this land was exempted. ${ }^{277}$ Land was exempted from State appropriation if the family, which owned the land, cultivated the land themselves, was in continuous possession of the land since 1948 and if most of the family were Burmese citizens. ${ }^{278}$ Holders of exempted land were instead granted limited rights over the land ${ }^{279}$ with restrictions to the size of farms they could hold. ${ }^{280}$ These rights continued as long as cultivators complied with applicable government regulations. ${ }^{281}$

\footnotetext{
${ }^{274}$ For example, during the depression of the 1930s, global rice demand plummeted as well as its price and many rice plantations foreclosed due to unpaid debt. Consequently, in the early 1930s, nearly half of the agricultural land in Myanmar's delta region was owned by non-agriculturalists, such as Indian Chettiar moneylenders. Elson, above n 6, at 134-5; Brown, above n 7, at 8.

275 Article 30(1). Leckie and Simperingham, above n 261, at 1103; This fundamental position has been maintained through both the 1974 and 2008 constitutions. Section 18 Constitution 1974 At 1194; Subsection 37(a). Constitution of the Republic of the Union of Myanmar 2008 (Myanmar).

${ }^{276}$ Leckie and Simperingham, above n 261, at 27.

277 Section 5, Land Nationalisation Act 1953. At 513.

${ }^{278}$ Section 6, Land Nationalisation Act 1953. At 514; Ikuko Okamoto and Ajia Keizai Kenkyūjo (Japan) Economic disparity in rural Myanmar (IDE-JETRO: NUS Press, Singapore, 2008) at 14; Leckie and Simperingham, above n 261, at 27.

${ }^{279}$ Section 9, Land Nationalisation Act 1953. Leckie and Simperingham, above n 261, at 519.

280 Schedule I, Land Nationalisation Act 1953 At 535.

${ }^{281}$ Subsection 11(1) Land Nationalisation Act 1953. At 521; Okamoto and Ajia Keizai Kenkyūjo (Japan), above $\mathrm{n} 278$, at 14 .
} 
Exemption requirements excluded landlords of agricultural land from State recognition of land rights. Existing agreements, contracts, grants or deeds, such as leases and share cropping agreements were voidable. ${ }^{282}$ However, compensation was paid to any landowner whose existing rights in land were appropriated or undermined by the State. ${ }^{283}$ Land appropriated by the State was then redistributed. This was undertaken by Village Land Committees. ${ }^{284}$

Although well-intentioned, in practice the acquisition and re-distribution of agricultural land to landless farmers under the Land Nationalisation Act was slow-moving. The process was hampered by civil conflict, lack of trained personal and corruption. ${ }^{285} \mathrm{By}$ 1963 only 17.1 per cent of land had been re-distributed to farmers approved by village Land Committees (and their subsequent bureaucratic forms). ${ }^{286}$ Saito states that this left a dual system in which areas where the Land Nationalisation Act was enforced, farmers had only cultivation rights. Whereas, in areas where it was not yet enforced, ownership was tacitly allowed. ${ }^{287}$

Despite the lack of success in nationalising agricultural land, the Nationalisation Act 1953 remained the cornerstone of land rights recognition until it was repealed by the Farmland Act 2012. There is minimal information about the process of how land rights were granted or recognised between 1953 and 2012. A land-holder was required to submit an LR 103 form to the SLRD in order for the department to survey the land and issue a certified map of the land. ${ }^{288}$ The SLRD also reportedly granted land use rights with proof of continuous cultivation. ${ }^{289}$

(c) Revolutionary Council (1962-1974) and BSPP Control (1974-1988)

After stalled elections and a caretaker government, negotiations after the stalemate of Burma's 1960 elections suggested that the Union of Burma would disintegrate. In 1962 the military intervened by staging a coup. The military government, called the Revolutionary Council was more staunchly socialist. The government valued socialist economic policy

\footnotetext{
${ }^{282}$ Section 5, Land Nationalisation Act 1953 Leckie and Simperingham, above n 261, at 513.

${ }^{283}$ Section 42, Land Nationalisation Act 1953. At 531.

${ }^{284}$ Khin Maung Kyi "Modernization of Burmese Agriculture: Problems and Prospects" [1982] Southeast Asian Affairs 115 at 122; Taylor, above n 7, at 351.

${ }^{285}$ Brown, above $\mathrm{n} 7$, at 97.

286 Taylor, above n 7, at 351; Teruko Saitõ "Farm Household Economy Under Paddy Delivery System in Contemporary Burma" (1981) 19 The Developing Economies 396 at 369.

${ }^{287}$ Saitõ, above n 286, at 369.

${ }^{288}$ Food Security Working Group, above n 41, at 44; UN Habitat and UNHCR Guidance Note on Land Issues - Myanmar (UN Habitat and UNHCR, 2010) at 13.

${ }^{289}$ Called U Paing. Thein, above n 84, at 41; Land Core Group of the Food Security Working Group, above n 84 , at 14.
} 
and equity above productivity. Nationalisation of marketing and industries was expanded, the economy was centrally planned and land sales continued to be restricted. ${ }^{290}$ In 1974 , the government drafted a new constitution in the style of the Eastern European one-party state. $^{291}$

Given the slow movement of nationalisation of agricultural land under the Land Nationalisation Act, the Revolutionary Council introduced the Tenancy Act 1963 and Tenancy (Amendment) Act 1965 in order to complete the process. Under the Tenancy Act 1963, the Village Security and Administrative Committee (SAC) rather than the landlord would decide the tenants for agricultural land. The government could grant leases irrespective of existing property rights over the land. Payment of rent in kind was also prohibited, ${ }^{292}$ and an upper limit on tenancy rents was established instead. ${ }^{293}$ The Tenancy (Amendment) Act 1965 finalised the nationalisation process by totally prohibiting private tenancies. $^{294}$

In terms of tenancy reform, these laws did little more than push existing tenancy practices underground. In the rural village Than surveyed, he noted that the number of tenant-farmers had increased between 1960 and 1980. ${ }^{295}$ Okamoto et al also noted the existence of tenancy contracts in 2003. ${ }^{296}$ Unofficial leases or transfers of land use rights were relatively common and officials tolerated them. ${ }^{297}$ Cultivators were more cautious about transferring or leasing paddy fields, as they were more stringently controlled. Whereas, upland fields growing vegetables were dealt with in a more open fashion. ${ }^{298}$

(d) Control of agricultural production and marketing

A result of the abolition of private tenancies pursuant to the Tenancy Amendment Act 1965 was that farmers were further controlled by the State. The government through village SACs regulated all agricultural land use. ${ }^{299}$

\footnotetext{
${ }^{290}$ Kyi, above n 284, at 121.

291 Mya Than "Little Change in Rural Burma: A Case Study of a Burmese Village (1960-80)" (1987) 2 Sojourn: Journal of Social Issues in Southeast Asia 55 at 80.

292 Tenancy Law 1963, s 4(3)

293 Tenancy Law 1963 s 4(1) Saitõ, above n 286, at 369.

294 Tenancy (Amendment) Act 1965 s 3 substituted s 4 in the Tenancy Act 1963. At 369; Kyi, above n 284, at 122 .

295 Than, above n 291, at 64.

296 Ikuko Okamoto and others Rich Periphery, Poor Center: Myanmar's Rural Economy under Partial Transition to Market Economy (2003) at 7.

297 Okamoto and Ajia Keizai Kenkyūjo (Japan), above n 278, at 20-21; UN Habitat and UNHCR, above n 288 , at 10 .

298 Saitõ, above n 286, at 392; Taylor, above n 7, at 352.

${ }^{299}$ Saitõ, above n 286, at 394-395.
} 
Although not wholly successful in reforming tenancy of agricultural land, the Tenancy Laws helped enable the expansion of the paddy procurement scheme. ${ }^{300}$ In 1963, the new military government went further and nationalised the marketing of all rice production. ${ }^{301}$ They prohibited private trade in rice. Under the procurement scheme, every cultivator was obligated to sell a portion of their crop to a government-run paddy purchase centre. The farmer would live on the remainder of the rice. The required quota was based on the average yield per acre and the size of the farm. ${ }^{302}$ The government payment for rice was much lower than the free (black) market price. ${ }^{303}$ If they did not comply with government regulations, they could be fined, imprisoned or their land could be confiscated. ${ }^{304}$

Despite being formulated in order to encourage higher production, Soe and Fisher conclude that the policy dis-incentivised increased yields and discouraged large landholders. It also led to the fragmentation of farmland in Myanmar, although this was felt more strongly in delta areas. ${ }^{305}$

During the latter part of this period, the government increased the procurement price in order to discourage the widespread black-market trade in rice. ${ }^{306}$ Myanmar's procurement system became the state's primary instrument to prevent the commercialisation of agricultural land. ${ }^{307}$ If farmers did not meet the required procurement quota, they could have been required give up their land. ${ }^{308}$ However, many farmers attempted to avoid these quota requirements. 309

\section{$4 \quad$ SLORC and SPDC Control (1988-2011)}

As came more towards end of socialist period, it became clearer that Burma was in economic crisis. ${ }^{310}$ Amidst a series of social and political crises involving rioting, police brutality and the breakdown public order, the president, Ne Win resigned and dissolved the

\footnotetext{
300 Taylor, above n 7, at 354; Saitõ, above n 286, at 391-2.

${ }^{301}$ Brown, above n 7, at 141.

${ }^{302}$ Saitõ, above n 286, at 370 .

303 Taylor, above n 7, at 354.

${ }^{304}$ Leckie and Simperingham, above n 261, at 29.

305 Mya Than and Loong-Hoe Tan Myanmar dilemmas and options (ASEAN Economic Research Unit, Institute of Southeast Asian Studies, Singapore, 1990) at 144.

${ }^{306}$ Myat Thein Economic Development of Myanmar (Institute of Southeast Asian Studies, 2004) at 93.

${ }^{307}$ Saitõ, above n 286, at 395.

308 Section 29 Land Nationalisation Act 1953. Leckie and Simperingham, above n 261, at 529; Although apparently confiscation simply for not reaching production targets was not common. Rather, the defaulted amount could be paid in the following season. UN Habitat and UNHCR, above n 288, at 5.

${ }^{309}$ Kyi, above n 284, at 122.

${ }^{310}$ For example, in December 1987, the United Nations declared Burma to be a "Least Developed Country" in order for it to receive greater financial assistance. Taylor, above n 7, at 379 and 382.
} 
BSPP. The army seized power and formed the State Law and Order Restoration Council (SLORC). ${ }^{311}$ They continued to hold power despite the 1990 elections. ${ }^{312}$ The SLORC was then restructured in 1997 as the State Peace and Development Council (SPDC) ${ }^{313}$ which controlled government until the Union Solidarity and Development Party (USDP) was inaugurated in March 2011 after elections in 2010. ${ }^{314}$

Through the socialist period Burma had attempted to remain independent and selfsufficient. ${ }^{315}$ However, its financial woes indicated that their economy required external interaction. In the final year before the BSPP disintegrated, they passed the first of Myanmar's agricultural reforms which would begin to move the country towards an economic growth model. ${ }^{316}$ The SLORC continued Myanmar's economic reforms and encouraged economic liberalisation and greater foreign engagement. This was reflected in the legislation passed by central government. They abandoned many of the socialist policies of the previous government. There was growth in domestic markets as well as increased foreign investment and non-state entities becoming involved in resource extraction.

(a) International engagement

Through the previous socialist period, Burma became known as a pariah state. ${ }^{317}$ It aimed to be self-sufficient and resisted foreign engagement. While this policy did not change until the SLORC came into power, the economic problems that began to surface in the late 1970s forced Burma to become more reliant on foreign aid. ${ }^{318}$

In a dramatic change in foreign policy, in the second half of the 1980s, the State passed a series of laws which opened Myanmar to foreign investment. Just two months after obtaining control, the SLORC passed the Foreign Investment Law 1988. ${ }^{319}$ This law allowed fully foreign-owned companies or joint ventures to invest in Myanmar, with the approval of the Foreign Investments Committee. ${ }^{320}$ It also opened the possibility of foreign investment in land. Since this time, foreign and local investment in land has been

\footnotetext{
311 At $384-6$.

312 At $410-412$.

313 At 479.

${ }^{314}$ Crouch and Lindsey, above n 7, at 203-204.

315 Taylor, above n 7, at 375-376.

${ }^{316}$ Brown, above n 7, at 176; Leckie and Simperingham, above n 261, at 578.

317 John Buchanan, Kevin Woods and Tom Kramer Developing Disparity: Regional investment in Burma's Borderlands (Transnational Institute) at 27.

318 Taylor, above $\mathrm{n} 7$, at 375-376.

${ }^{319}$ Brown, above $\mathrm{n} 7$, at 176.

${ }^{320}$ At 176-177; Mya Than and Tan, above n 305, at 187-188, 195 and 198.
} 
encouraged by the Myanmar government. Foreign investment is also incentivised through tax benefits. 321

(b) Development of unused land

The SLORC abandoned the policy of crop planning, which enabled farmers to sell previously controlled produce on the domestic market. ${ }^{322}$

The transition from a socialist planned economy to a capitalist market economy meant the value of 'equity above productivity' under the previous government was reversed. There was more domestic and international demand for land.

The State passed the Duties and Rights of the Central Committee for the Management of Culturable Fallow Land and Waste Land 1991 ("Wasteland Law") in order to address the need for more productive land. It aimed to convert perceived wasteland into cultivated land. The legislation established the Central Committee for the Management of Culturable Land, Fallow Land and Waste Land ("Central Committee"). The Central Committee was able to allocate large sections of land deemed fallow or waste to State owned enterprises and approved foreign investors. ${ }^{323}$ However, the size limitations of 5,000 acres were increased to 50,000 acres in a 1998 amendment to the Procedures Conferring the Right to Cultivate Land/Right to Utilize Land 1991 (Wasteland Procedures) through lobbying by foreign investors. ${ }^{324}$ Allocations were in the form of 30 year leases. 325 The maximum size of land allocation depended upon the type of agricultural or horticultural land use. ${ }^{326}$ Certain exemptions from land taxes were also granted under this legislation. ${ }^{327}$

Although until 2012 it remained illegal to transfer land other than by inheritance, as Myanmar increasingly became a market economy from the late 1980s onward, informal transfers of land rights also increased. SLRD officials would transfer land use rights for a

\footnotetext{
${ }^{321}$ OECD, above n 146, at 86.

${ }^{322}$ Brown, above n 7, at 176; Taylor, above n 7, at 76; Okamoto and Ajia Keizai Kenkyūjo (Japan), above n 278 , at 18 .

323 Duties and Rights of the Central Committee for the Management of Culturable Fallow Land and Waste Land 1991 (Myanmar), subs 3(a).

${ }^{324}$ Procedures Conferring the Right to Cultivate Land / Right to Utilize Land for Agricultural and Livestock Breeding Purposes (Amendment) 1998 (Myanmar), s 2; Kim Kyung-Ryang and Jemal Abafita "Agricultural Development in Myanmar: Lessons from Korean Experience” (2012) 24 Korean J Intl Agri 136 at 142 ; Leckie and Simperingham, above n 261, at 34; Food Security Working Group, above n 41, at 28.

${ }^{325}$ Duties and Rights of the Central Committee for the Management of Culturable Fallow Land and Waste Land 1991 (Myanmar), subs 3(b)(i).

326 Duties and Rights of the Central Committee for the Management of Culturable Fallow Land and Waste Land, subs 3(a); Leckie and Simperingham, above n 261, at 34.

${ }^{327}$ Duties and Rights of the Central Committee for the Management of Culturable Fallow Land and Waste Land, s s 16 and 17; Leckie and Simperingham, above n 261, at 34 and 611.
} 
bribe. ${ }^{328}$ The Burmese government overlooked such activity so long as it did not harm state interests, ${ }^{329}$ in particular the state priority of rice security. ${ }^{330}$

(c) Forestry policy

Some of the first beneficiaries of the change in foreign investment laws in the late 1980s were Chinese and Thai logging companies. Logging concessions were granted over areas along the Thai-Myanmar border. Through the 1990s, Thai logging companies extensively cleared forests in this region. Also ethnic militia which made cease-fire agreements in the late 1980s sold logging concessions to neighbouring countries in order to generate income. In the late 1990s and 2000s, activity moved into Northern Myanmar along the SinoMyanmar border. ${ }^{331}$

Although foreign engagement made Myanmar more vulnerable to exploitation, it also led to international pressure to bring its legislation in line with international standards. ${ }^{332}$ The rise of conservationism has been a significant geo-political force in Southeast Asia in the last two decades. ${ }^{333}$

(d) Forestry Policy

The 1992 Forest Law replaced its 1902 colonial predecessor. The new law kept much of the content of the colonial law. ${ }^{334}$ However, although falling short of recognising local claims of access and use, ${ }^{335}$ it enabled some decentralisation of control over forests through increased private sector and community involvement.

The law also extended forestry management to also consider environmental and social factors. In passing this law, the Burmese government hoped to expand reserved forests from primarily in Central Myanmar into outer areas. ${ }^{336}$ The Forestry Department then issued the

\footnotetext{
328 Ashley South, Maria Katsabanis and Centre on Housing Rights and Evictions Displacement and disposession forced migration and land rights in Burma (COHRE, Geneva, 2007) at 49.

${ }^{329}$ Okamoto and Ajia Keizai Kenkyūjo (Japan), above n 278, at 18.

330 Jairo G Castano Thematic Papers on Myanmar Census of Agriculture 2010 (2013) at 8.

${ }^{331}$ Kevin Woods Baseline Study 4, Myanmar: Overview of Forest Law Enforcement, Governance and Trade (Forest Trends, 2011); Kevin Woods "Ceasefire capitalism: military-private partnerships, resource concessions and military-state building in the Burma-China borderlands" (2011) 38 Journal of Peasant Studies 747.

332 Bryant, above $n$ 81, at 347-348.

${ }^{333}$ Fox and others, above n 2, at 309.

${ }^{334}$ Such as, reinforcing that teak trees remained State property wherever they were planted. Kyaw Tint and others "Unleashing the potential of community forest enterprises in Myanmar" at 37.

335 Woods, above n 331, at 19.

${ }^{336}$ Bryant, above n 189, at 181-3; Istituto Oikos and BANCA Myanmar Protected Areas: Context, Current Status and Challenges (Ancora Libri, Milano, Italy, 2011) at 12-3.
} 
Community Forest Instructions (CFI) in $1995 .{ }^{337}$ The CFI were created in order to promote community involvement in Forestry management. ${ }^{338}$ The instructions aimed to both protect forests, through replanting, and provide needed forest products to communities. ${ }^{339}$

Under these instructions, villages are able to form a Forest Users' Group (FUG) and be granted an area of forestland as community forest ${ }^{340}$ to manage under a community forestry management plan. ${ }^{341}$ The Community Forest Establishment Certificate could be revoked if the management plan is breached or neglected. ${ }^{342}$

(e) 2008 Constitution

The political, economic and social instability in the late 1980s and early 1990s led to a series of political crises and changes of power. The SLORC did not relinquish power in 1990 after losing the elections. The process of writing a new constitution which encapsulated the economic and political changes Myanmar experienced commenced shortly afterwards ${ }^{343}$ and was finally completed in 2008. ${ }^{344}$

Aspects that remained the same as previous constitutions are that the state is deemed the ultimate owner of land and natural resources. ${ }^{345}$ Although s 37(c) also states that the State "shall permit citizens right of private property, right of inheritance, right of private initiative and patent in accord with the law."

The greatest change was the statement enshrining that Myanmar has a marketdriven economic system, ${ }^{346}$ where exploitation of natural resources is undertaken in a free-

${ }^{337}$ pursuant to s 57 (b) of the Forest Law 1992

338 Tint, Springate-Baginski and Mehm, above n 21, at 18.

339 Tint and others, above n 334, at 7; Section 1 Community Forestry Instructions Tint, Springate-Baginski and Mehm, above n 21, at 85.

${ }^{340}$ Section 15 of the Forest Law 1992 and ss 6-10 Community Forestry Instructions 1995 Tint, SpringateBaginski and Mehm, above n 21, at 85.

341 Section 15, Community Forestry Instruction. Woods, above n 331, at 15; Tint, Springate-Baginski and Mehm, above n 21, at 86.

${ }^{342}$ Section 16, Community Forestry Instructions 1995. Tint, Springate-Baginski and Mehm, above n 21, at 86.

343 Dominic Nardi "Discipline-flourishing Constitutional Review: A Legal and Political Analysis of Myanmar's New Constitutional Tribunal” (2010) 12 Australian Journal of Asian Law 1 at 9.

344 It was approved by public referendum amidst inauspicious circumstances. The constitutional referendum was scheduled for 10 May 2008. However, on 2 May 2008, Myanmar was devastated by Tropical Cyclone Nargis. Tin Maung Maung Than "MYANMAR in 2008: Weathering the Storm" (2009) 2009 Southeast Asian Affairs 195 at 196-197; Despite this, the government continued to hold the referendum on 10 May and delayed it for only 2 weeks in areas affected by the cyclone. Taylor, above $n$ 7, at 487; There were widespread accusations of electoral irregularities, coercion and vote-rigging Nardi, above n 343, at 9; Crouch and Lindsey, above n 7, at 203.

345 Constitution of the Republic of the Union of Myanmar 2008 (Myanmar), s 37.

${ }^{346}$ Constitution of the Republic of the Union of Myanmar, s 35. 
market environment. Nationalisation was also expressly prohibited in order to encourage foreign investment. ${ }^{347}$

\section{Land Classifications Prior to 2012}

An important aspect of the SLM in Myanmar is land classifications. All land in Myanmar is divided into various categories. However, these administrative categories are often inconsistent with the physical reality on the ground. ${ }^{348}$ The various land categories increased with Myanmar's often incongruous land legislation spanning from pre-colonial times into the $21^{\text {st }}$ Century.

The treatment of different types of land in different ways has occurred since precolonial times in Myanmar. However, colonisation had the greatest impact in this regard. Like many other Southeast Asians countries, Myanmar also underwent colonial land classification. It was originally introduced in Colonial times for taxation purposes and to try and simplify the complex land systems that existed in Upper Burma. ${ }^{349}$ Under the colonial system agricultural land was taxed and non-agricultural land was either nominally taxed or exempt from taxation. ${ }^{350}$ Some of these land categories overlapped and it was possible to transition from one to another. The UN-HABITAT outlined 11 overlapping categories in their 2010 Guidance Note on Land Issues in Myanmar. ${ }^{351}$

(a) Changing between land categories

Prior to 2012, any changes to land categorisation were made through s 39 of the Land Nationalisation Act 1953. ${ }^{352}$ Under this provision, the president could deem or delegate authority to deem any land as agricultural or non-agricultural land. This power was delegated to the SPDC before the council was dissolved in March 2011. ${ }^{353}$ They would issue a certificate granting permission for the particular land use to be altered. ${ }^{354}$ This centralised authorisation model meant applications for changes in land categorisation took a considerable amount of time to be approved. ${ }^{355}$

\footnotetext{
${ }^{347}$ Constitution of the Republic of the Union of Myanmar, ss 36(d).

348 Tony Burns Land Administration Reform: Indicators of Success and Future Challenges (World Bank, 2007) at 19.

349 Taylor, above n 7, at 89-92; Thant Myint-U, above n 7, at 10.

${ }^{350}$ Food Security Working Group, above n 41, at 25.

351 Freehold Land, Grant Land, Agricultural Land, Garden Land, Grazing Land, Culturable Land, Fallow Land and Waste Land, Forest Land, Town Land, Village Land, Cantonments and Monastery Land. UN Habitat and UNHCR, above n 288, at 1-2.

352 This provision was known as "La Na 39". UN Habitat and UNHCR, above n 288.

${ }^{353}$ At i and 13; Food Security Working Group, above n 41, at 47.

${ }^{354}$ UN Habitat and UNHCR, above n 288, at i.

${ }^{355}$ Food Security Working Group, above n 41, at 47.
} 


\section{Summary}

The SLM system in each period of Myanmar's history has been heavily influenced by the political and economic climate of the day. The changes between these periods have often been characterised by pendulum-like shifts in policy as successive governments have attempted to alleviate the land issues they inherited. The complexity, inefficiency and weakness of the pre-colonial SLM system was replaced by a rationalised, capitalist colonial regime with expansive reach. The issues of landlessness and extensive foreign control through the colonial period were countered by post-independence nationalistic socialism, which promoted more egalitarian distribution of natural resources as well as economic and political isolation. However, when this economic system failed, the SLORC re-established a more liberalised economy although still heavily controlled by the military. As these periods have passed, some aspects of the SLM system have altered dramatically. However, others remained leaving Myanmar with a complex and fragmented system. 


\section{Interaction between SLM and CLM systems}

The SLM in Myanmar has not operated in isolation, rather the SLM system along with CLM systems represent alternative mechanisms of access by which actors access swidden land held customarily. As interrelated mechanisms of access, SLM and CLM systems may conflict or complement each other. ${ }^{356}$ Because the circumstances affecting both of these systems shift over time, the power which can be exercised through either mechanism also changes. Toulmin et al emphasise how much CLM systems are influenced by the SLM system and they do not operate independently of each other. ${ }^{357}$

The interaction between SLM and CLM systems in Myanmar can be analysed in light of access to swidden land. As external factors have strengthened SLM mechanisms of access to swidden land, this has undermined the strength of CLM systems.

CLM systems managing swidden cultivation have remained relatively detached from overarching frameworks implemented by the State. This has enabled traditional land management systems to continue in many areas. Distance and isolation from centralised bureaucratic control along with the cost of establishing and maintaining these controls have perpetuated existing localised structures. This has helped insulate customary land management systems from radical political shifts and enabled them to prevail in areas where swidden is practised. When there has been interaction between statutory and customary law, if CLM systems were aligned to state goals, they were supported. However, when at odds, they were opposed.

\section{$1 \quad$ Pre-colonial}

There is limited information about the pre-colonial interaction between CLM and SLM systems. Swidden cultivation was prevalent in the outer, hilly regions of Myanmar ${ }^{358}$ and was perceived as an activity which distinguished hill tribes from larger cultural groups with more sedentary agricultural practices. ${ }^{359}$ These areas were, and continue to be populated by diverse and dispersed ethnic minorities. ${ }^{360}$ Although often viewed as a primitive agricultural practice, ${ }^{361}$ Scott hypothesises that swidden cultivation was developed as a

\footnotetext{
${ }^{356}$ Ribot and Peluso, above n 35, at 170; Hall's description of the inconsistencies, overlaps and fuzziness of land management in Southeast Asia highlights points at which power over land access can be contested. Hall, Hirsch and Li, above n 52, at 12; Sturgeon and Sikor, above n 57.

357 Toulmin, Lavigne Delville and Traoré, above n 186, at 8.

358 Myint Aung, above n 124, at 189; Stevenson, above n 191; Leach, above n 193.

${ }^{359}$ Such as distinguishing from being "Shan". Scott, above n 105, at 82; Leach, above n 193, at 22.

${ }^{360}$ Scott, above n 105, at 14; Jane M Ferguson "The scramble for the Waste Lands: Tracking colonial legacies, counterinsurgency and international investment through the lens of land laws in Burma/Myanmar: Burma/Myanmar Waste Lands” (2014) 35 Singapore Journal of Tropical Geography 295 at 297.

361 Baver and others, above n 136, at 37.
} 
specific strategy to avoid and undermine state governance and avoid interaction with the SLM system. ${ }^{362}$ State power weakened as it extended into Burma's surrounding hillcountry. ${ }^{363}$ In peripheral areas to the state, land was cleared without the need for registration. ${ }^{364}$ During this period swidden farmers were able maintain their practices in relative autonomy. The most interaction between these two systems was the periodic payments of tribute to those controlling the SLM system. ${ }^{365}$

Some aspects of both the SLM and CLM systems were similar. This is because the Burmese understood customary law to be the only source of law and therefore incorporated it into their SLM system. ${ }^{366}$ For example, both recognised that land rights could be established through the act of first clearance. They also both recognised the consolidation of these rights through inheritance. ${ }^{367}$

\section{Colonial Period (1825-1948)}

Colonisation by the British significantly altered some of the factors influencing the interaction between the SLM and CLM systems. ${ }^{368}$ They rationalised state objectives and values into control and the generation of wealth. The power of the State was strengthened in outlying areas. ${ }^{369}$ They also sought to generate wealth, such as, through taxes, exploitation of natural resources and the conversion of wastelands into productive lands.

As the colonial state extended its power into hill-country areas, the SLM system interacted with CLM systems. When CLM systems were aligned with colonial objectives, the State supported, protected or even incorporated it into the SLM system. However, when CLM systems opposed these objectives, the administration ignored and overrode them. In these circumstances, the SLM system was extended over top of existing customary structures.

(a) Control

Colonial objectives resulted in hill-country areas generally being governed differently to flat, delta areas. ${ }^{370}$ When the British annexed Burma as a colony, they divided off its hilly

\footnotetext{
362 Scott, above n 105 , at 191.

363 Taylor, above $\mathrm{n} 7$, at 21-23.

364 At $40-3$.

365 At 23; Scott, above n 105, at 60 .

${ }^{366}$ Aung, above n 245, at 10.

${ }^{367}$ Furnivall, above n 194, at 50.

368 Taylor, above n 7, at 150.

369 Vandergeest and Peluso, above n 65.

370 Taylor, above n 7, at 80 .
} 
borderlands as "Frontier Areas." 371 These were areas where swidden cultivation was primarily practiced, whereas lowland areas supported wet rice cultivation.

As only a minimal amount of revenue could be raised from hilly areas, it was politically and economically expedient to leave CLM systems with local leadership structures virtually intact. ${ }^{372}$ The British substituted itself in the place of the monarch to whom these leaders would pledge allegiance and pay tribute. ${ }^{373}$ The transition in the interaction between the SLM and CLM systems in these areas was therefore relatively smooth. As long as customary leadership structures allowed colonial powers to have overall authority, the status quo did not significantly change. ${ }^{374}$

However, as British colonial control extended further and more successfully than the pre-colonial state, CLM systems in these areas began to be weakened. ${ }^{375}$ For example, the British began to rationalise control through standardising tributary payments for hillcountry plots. ${ }^{376}$ While the British allowed village heads to exercise a lot of freedom in their governance, some of this was curtailed. ${ }^{377}$

Under the SLM system, so-called frontier areas were governed under different statutes which allowed many local matters to be governed by traditional leadership applying customary law. For example, the Kachin Hills Manual recognised the customary authority of Kachin village heads. Likewise, the Chin Hills Regulation 1896, and the Chin Special Division (Extension of Laws) Act 1948 dealt with local customs practiced in Chin State. ${ }^{378}$ Near the end of Colonial rule the government passed the Government of Burma Act 1935 which also enabled different geographical regions in Myanmar to be governed by different laws. It allowed local village leaders, enforcing customary law to govern issues of land use rights. These rules were collated into manuals for each region. ${ }^{379}$ As areas were so remote, they would also be more likely to resolve disputes using customary systems rather than through government officials. ${ }^{380}$ This form of governance enabled the British to indirectly control the outer regions of Myanmar without establishing expensive

\footnotetext{
${ }^{371}$ Smith, above $\mathrm{n} 7$, at 43 .

372 Taylor, above n 7, at 81; Food Security Working Group, above n 41, at 25; Thein, above n 124, at 41.

373 Taylor, above n 7 , at 82 .

374 At 88 .

375 Mya, above n 207, at 51.

${ }^{376}$ For example, in Arakan (Rakhine) State, each tribe was required to pay 1 rupee for each hill clearing. Taylor, above n 7, at 88 .

377 Stevenson, above n 191, at 81.

378 Burma Environmental Working Group, above n 8, at 37.

${ }^{379}$ Food Security Working Group, above n 41, at 19.

${ }^{380}$ South, Katsabanis and Centre on Housing Rights and Evictions, above n 328, at 55.
} 
administrative systems.

(b) Wealth Generation

The British aimed to generate wealth in the country through the production, processing and extraction of natural resources within the framework of a capitalist economy. A foundational aspect of achieving this was through the commodification of land. This enabled an active land market and credit system to develop. ${ }^{381}$ The colonial administration was also able to obtain taxes and introduce European business interests into the country. ${ }^{382}$

The British encouraged the conversion of lowland swamp and jungle in Lower Burma into wet-rice cultivation plantations. In order to do this, they incorporated a modified version of practice of dama-ugya into the Lower Burma Land and Revenue Act 1876. The legislation enabled land to be converted into ownership through occupation for 12 years, so long as the occupant paid land revenue on the piece of land continuously during this period.

However, the changes in economic values also brought the SLM and CLM systems into conflict. Swiddeners predominantly practiced subsistence lifestyles, whereas British colonists encouraged integration with global commodity markets. Tension arose between these two positions especially around the value of certain natural resources.

More remote and outlying areas were too far from markets and too difficult to access. The ability for the agents of the SLM system to benefit from using the natural resources in these areas was limited. They were therefore able to continue to be governed customarily in order to support subsistence lifestyles. However, in areas close enough for European resource extraction enterprises to access, the State sought to protect these valuable assets through the SLM system. ${ }^{383}$

One of the foremost examples of how protection of resource negatively affected customary land rights over swidden land was with regard to teak. Burma's teak forests were of great value. ${ }^{384}$ There was a tension between the State ownership of forestry in order to exploit timber resources and the surrounding population who relied on forests for economic and social survival. ${ }^{385}$ The use of teak trees became a point of conflict between Karen swidden cultivators and British Colonists.

As swidden farmers had no use for teak wood, they would simply burn it along with the rest of the forest which was not cleared prior to planting ready for the rainy season.

\footnotetext{
${ }^{381}$ Furnivall, above n 194.

382 Taylor, above n 7, at 89-92.

383 Bryant, above n 189; Bryant, above n 81.

${ }^{384}$ Bryant, above n 189, at 57 and 229.

${ }^{385}$ At 57.
} 
Swiddeners favoured areas where teak trees were most plentiful in order to burn swidden fields as the land was more fertile in these areas. ${ }^{386}$

(c) British interventions

The British strengthened the SLM system in order to protect this resource. They achieved this through a number of different strategies. Each strategy affected existing CLM systems as they attempted to prevent teak being destroyed through burning. They focused their efforts on the Pegu Yoma, where Karen communities practiced swidden cultivation. ${ }^{387}$

(d) Establishing reserved forests

The British colonialists wanted to assert authority over forested areas, as state control was weakest there, ${ }^{388}$ and generate a more sustainable system of forest management. ${ }^{389}$ The British first enacted the Forestry Act 1881 which established a forestry system similar to the model used in Germany. It was heralded as introducing a 'scientific model' of forestry to Burma. ${ }^{390}$ The Forestry Act 1902 then consolidated State powers over forestry land and resources which were instigated in the 1881 Forestry Act. ${ }^{391}$ It allowed the Forestry Department to appropriate areas of valuable forest land ${ }^{392}$ and deemed teak trees to be state property. ${ }^{393}$

(e) Restricting swidden rights and practices within reserved forests

The 1881 Forestry Act also aimed to clarify who held rights over forestry land in Burma. It recognised the customary rights of settled agriculturalists to access forests. However, swidden cultivation was not recognised as providing sufficient evidence of customary entitlement to reserved forest land. This was because the British did not view sedentary cultivation as impeding the extraction of teak. ${ }^{394}$ Whereas swidden land use rights were perceived as amorphous and not easily defined. Bryant, citing Brandis, records that Karen

\footnotetext{
${ }^{386}$ Bryant, above n 81, at 229.

387 At 247.

388 At 227.

389 At 227-9.

${ }^{390}$ Raymond L Bryant “The Greening of Burma: Political Rhetoric or Sustainable Development?” (1996) 69 Pacific Affairs 341 at 343.

${ }^{391}$ Bryant, above n 189, at 99.

392 At 60 .

${ }^{393}$ Such as, reinforcing that teak trees remained State property wherever they were planted. Tint and others, above n 334, at 37.

${ }^{394}$ Bryant, above n 189, at 60.
} 
swiddeners would have customary claims to the vast majority of the Pegu Yoma. ${ }^{395}$ Granting land use rights of land to swiddeners would have prevented foresters from exclusive access to teak forests, reduced colonial power over these forests and impeded colonial forestry operations. ${ }^{396}$ The Forestry Act emphasised swidden land use as a privilege, which could be modified or withdrawn, rather than a right. ${ }^{397}$ Consequently, the Forestry Act also allowed swidden fallows to be taken by the Forestry Department without any recompense or recognition of underlying customary rights. 398

The British also passed laws which restricted swidden practices. ${ }^{399}$ The legislation especially focused on preventing damage to teak trees by created swiddens through burning. For example, the Forest Rules 1865 required swidden cultivators to obtain permits prior to clearing and burning forested land. The penalty for breaching the rules was a fine of up to 200 rupees or 6 months imprisonment. ${ }^{400}$

(f) Introducing taungya teak planting

The Karen resisted the British introduction of reserved forests as it interfered with their CLM systems. Brandis, the Superintendent of Forests in Pegu, then developed taungya teak planting. ${ }^{401}$ In this system, swidden cultivators were paid by the Burmese Forestry Department in order to intersperse teak trees amongst their crops within a swidden fallow. 402 They would be able to produce crops for two seasons before the teak trees shaded out the crops. During this time, they would also weed and tend the young teak trees. A certain payment would then be made for each teak tree remaining after 2 years. After this time, the plot was then left and the teak trees were able to grow to maturity and the area became a state forest. After this, the workers would move to the next area and begin the process again in another area of land. ${ }^{403}$

Although initially resistant, the Karen eventually agreed to the system. This was achieved after certain areas of the forest were left as swidden fields rather than being converted into reserved teak forests through taungya teak planting. However, the long-term

\footnotetext{
395 At 69.

396 Bryant, above n 81, at 235.

${ }^{397}$ Bryant, above n 189, at 60.

398 At 60.

${ }^{399}$ Bryant, above n 81, at 236.

400 Sir Dietrich Brandis Report on the Teak Forests of Pegu, with a memorandum on the teak in the Tharawaddy Forests . 1856 (Stationery Office, 1860) at 53-7.

${ }^{401}$ Bryant, above n 81, at 231 and 234.

402 Nicholas Menzies "Three hundred years of taungya: A sustainable system of forestry in south China" (1988) 16 Human Ecology 361 at 363.

${ }^{403}$ Bryant, above n 81, at 226 and 237.
} 
colonial strategy was to sedentarise taungya teak planters. As teak forests take about 150 years to mature, but the rotational fallow cycle was 10-15 years, taungya teak planters began to lock up potential swiddens as state forests. As less agricultural land was available, families were forced give up swidden lifestyles. ${ }^{404}$

(g) Summary

For the most part, the SLM system imposed by the British allowed CLM systems to continue with minimal intervention. The separation between how hill-country and the delta plains were treated empowered CLM systems to continue through indirect colonial governance.

However, British colonisation laid the ideological and practical foundations which strengthened the SLM system. Colonial control and economic transformation also weakened CLM systems. This was either indirectly through the peace brought to hillcountry areas which reduced the power of local chiefs or directly through the protection of teak forests. Swiddening was viewed as not only primitive, but also destruction and a threat to economic prosperity and social stability. Because of this, within the Pegu Yoma, the SLM system actively prevented and restricted CLM systems through legislation and punitive sanctions.

\section{Independence (1948-1962), Revolutionary Council (1962-1974) and BSPP Control (1974-1988)}

Following from administrative practices established under Colonial rule, the postindependence SLM system in Burma has been based on centrally produced legislation. The Myanmar State in its various forms has drafted constitutional documents, statutes, regulations, government orders and policy reflecting the various ideological underpinnings of the government of the day. As Myanmar was under military control at different times between 1962 and 2011, the military also influenced how this legislation was implemented. 405

As Burma gained independence the altered political direction of the country brought about major transitions in the agricultural sector. However, the changes did not significantly affect swidden cultivation. Like legislation passed in colonial times the SLM interacted more practically with other forms of agriculture such as paddy farming. State legislation was again overlaid on top of existing customary structures. However, the inconsistency and slow-movement of reforms as well as the limited reach of State power meant that CLM systems often remained intact.

Although the practical implications of changes to the SLM system on CLM systems

\footnotetext{
404 At 243-4; Myint Aung, above n 124, at 189.

${ }^{405}$ Land Core Group of the Food Security Working Group, above n 83.
} 
were limited, the land reforms of the 1950s and 1960s dramatically altered the underlying legal recognition of land rights. In some ways these changes enabled the partial recognition of customary land use rights. However, overall, the recognition of land rights was weakened and the State established the platform for greater control of land resources along with the potential for the abuse of this power.

Customary rights were not recognised explicitly by Burma's legislation. Rather, they were recognised through 'land-use' or 'tillage' rights ${ }^{406}$ granted under Land Nationalisation Act 1953 and the Tenancy Law 1963. ${ }^{407}$ These land rights were legally passed on through ancestral legacy or laws of inheritance. ${ }^{408}$ Customary land rights were also made more tenuous by the largest group that land use rights could be granted to would be a household. ${ }^{409}$ Land use rights could not be granted to larger groups.

Most swidden land was not formally registered. In fact, Thein reports that the SLRD would not survey or register non-permanent swidden cultivation plots. ${ }^{410}$ Rather, SLRD officers maintained informal field notebooks which contained sketches of village boundaries and landmarks. It also contained information regarding the total amount of land cultivated in that village and each household's landholding. This information was updated annually for taxation purposes. ${ }^{411}$

(a) Restricting land markets

However, as during this period, political and economic policy moved away from Capitalism to Socialism, there was less market pressure on land resources. This meant that it was not legally or economically possible to accumulate large areas of land. Also as domestic markets in agricultural produce were illegal from the $1960 \mathrm{~s}$, there was no incentive to transition from subsistence lifestyles into dependence on cash crops.

The State also moved against foreign influence within Burma. Without the international demand for private property, there was also less upward pressure on land values within Burma. Swidden land was thereby protected from market pressures which could have led the land to be alienated.

\footnotetext{
406 Okamoto and Ajia Keizai Kenkyūjo (Japan), above n 278, at 14.

${ }^{407}$ Robert B Oberndorf Legal Review of Recently Enacted Farmland Law and Vacant, Fallow and Virgin Lands Management Law: Improving the Legal \& Policy Frameworks Relating to Land Management in Myanmar (Food Security Working Group's Land Core Group, 2012) at 14.

${ }^{408}$ Zaw and others, above n 163, at 352; Okamoto and others, above n 296, at 5 and 7; Than, above n 291, at 64.

${ }^{409}$ Subsection 3(e) Nationalisation Act 1953, Leckie and Simperingham, above n 261, at 514.

410 Thein, above n 124 , at 41.

${ }^{411}$ Food Security Working Group Land Tenure: A foundation for food security in Myanmar's uplands (Food Security Working Group, 2010); Thein, above n 124, at 41.
} 
(b) Control of agricultural production and marketing

Increased state control over agricultural and marketing also affected the CLM system to differing extents. The rice procurement scheme was a case in point. Although the nationalisation of rice marketing was implemented more extensively than the nationalisation of agricultural land, it was not enforced consistently. ${ }^{412}$ The more remote a village was, the less power the SLM system had and therefore the rice procurement scheme was less applicable. Accordingly, these centrally implemented laws had the least effect on swidden cultivators in upland regions and the regulations were often adapted to local conditions. ${ }^{413}$ The procurement of rice quotas in mountainous areas was patchy if not nonexistent. ${ }^{414}$

The State was also concerned about land being used productively. ${ }^{415}$ For example, the Nationalisation Act 1953 prevented land being left fallow. ${ }^{416}$ Fallow land or land not used in compliance with government regulations could be confiscated by the State. ${ }^{417}$ This made the choice of crops to use on swidden land more centrally driven. The requirement not to leave land fallow without good cause also directly affected swidden farmers, as this is an inherent part of the swidden cultivation process. It meant that this land was more vulnerable to State appropriation.

(c) Insurgency

Another significant factor which determined how swidden cultivation was affected was insurgent activity. The state administration had limited control in border regions. From the late 1940s onwards, Myanmar experienced continued military insurgency from armed ethnic groups controlling hill-country areas. Accordingly, in some areas customary swidden practices continued relatively unabated through the Socialist period. ${ }^{418}$

However, in the mid-1960s, the Burmese government also implemented the "Four Cuts" policy. ${ }^{419}$ In order to isolate insurgent forces, the Burmese army attempted to cut off

\footnotetext{
${ }^{412}$ Saitõ, above n 286, at 370 .

${ }^{413}$ At 370-2.

${ }^{414}$ At 370 .

${ }^{415}$ Ferguson, above $\mathrm{n} 360$, at 300 .

${ }^{416}$ Section 11 Nationalisation Act 1953 Leckie and Simperingham, above n 261, at 521 This was particularly in response to land being left fallow by money-lender landlords who had gained farmland through foreclosure.

${ }^{417}$ Sections 11 and 29, Land Nationalisation Act 1953, see At 521 and 529; South, Katsabanis and Centre on Housing Rights and Evictions, above n 328, at 47; Okamoto and Ajia Keizai Kenkyūjo (Japan), above n 278, at 14 .

${ }^{418}$ South, Katsabanis and Centre on Housing Rights and Evictions, above n 328, at 52; Taylor, above n 7, at 37-8; Bryant, above n 189, at 183.

${ }^{419}$ Smith, above $\mathrm{n} 7$, at 258-262.
} 
their food, funds, intelligence and recruits. They relocated villages, confiscated food, destroyed crops and forcibly recruited porters. ${ }^{420}$ Swidden rice crops were susceptible to elimination by the Burmese army because of their visibility. ${ }^{421}$ Conflict caused massive movements of population. ${ }^{422}$ In many of these areas, large tracts of land were left unpopulated after rebel groups were forced out. ${ }^{423}$

(d) Revolutionary Council (1962-1974) and BSPP Control (1974-1988)

The government maintained similar attitudes towards swidden cultivation affecting teak forest reserves as their colonial predecessors did. Swidden cultivation threatened these reserves and therefore the State sought to implement policies persuading swiddeners to take up a more sedentary lifestyle. ${ }^{424}$ Taungya teak planting projects also continued, particularly during the 1970s and early 1980s. Swiddeners were encouraged by the government to participate in taungya teak planting through various incentives, such as the provision of rice. However, once these were removed, the practice became uneconomical. ${ }^{425}$

(e) Bureaucratic administrative bodies

The form of local governance introduced by the British had been criticised. In lowland areas where they had destroyed the existing village governance system, it was criticised for being overly bureaucratic. However, in hill-country areas, it was criticised for allowing the continuation of autocratic governance by traditional leaders. ${ }^{426}$ The establishment of Village Land Committees and later People's Councils governing local affairs attempted to encourage more localised participatory governance. ${ }^{427}$ These administrative bodies were established throughout Burma, ${ }^{428}$ wherever the State retained political control.

By 1976, the role of the village SACs, which had been established under the Land Nationalisation Act, had diminished considerably. They had become ineffective in dealing with land disputes and had less of a role in allocating land. Rather, they had become a

\footnotetext{
${ }^{420}$ Ferguson, above n 360, at 303.

${ }^{421}$ Scott, above n 105, at 198.

${ }^{422}$ Smith estimates that there were over 1 million people left homeless after the first 2 years of insurgency. Smith, above n 7, at 119 and 476; and Butwell estimates there were 3 million refugees and internally displaced people through the first insurgency. Richard Butwell U Nu of Burma (Stanford University Press, 1969) at 98.

${ }^{423}$ Smith, above n 7, at 261.

${ }^{424}$ Hirsch and Warren, above n 53, at 112.

${ }^{425}$ Maung and Yamamoto, above n 87, at 40.

426 Taylor, above n 7, at 331 .

427 At 331.

428 Articles 29-31 Constitution of the Socialist Republic of the Union of Burma (1974) Leckie and Simperingham, above n 261, at 1196-1197.
} 
glorified land registry office. ${ }^{429}$ So, in 1976 , the role of the village SAC was subsumed into that of the executive committees of the People's Councils which managed local government affairs. ${ }^{430}$ The general implementation of these policies in areas previously controlled by CLM systems would have weakened these systems.

\section{SLORC and SPDC Control (1988-2011)}

The most profound effects on CLM systems occurred after the SLORC gained control in 1988. The previous administrations had strengthened state control of land resources through the SLM system and had correlatively weakened CLM systems. However, after the SLORC came into power, CLM systems faced the added pressure of economic development through market integration and foreign investment. While socialist economic policies had limited these pressures through inadvertently dis-incentivising productivity and economic growth, the transition to a State controlled market economy stimulated them.

The increase in foreign investment and domestic land markets increased the need for cultivable land. The SLORC pursued a policy of converting unused land into permanent agricultural plantations. Swidden fallows could be deemed unused wasteland and thereby allocated in agricultural concessions to state owned enterprises or foreign investors. These concessions were made without considering underlying customary land claims to the land.

However, as Myanmar began to engage economically with foreign countries, it began to face geo-political pressure from conservationist groups and other NGOs to protect Myanmar's environmental assets and recognise CLM systems. ${ }^{431}$ Some NGOs which accessed Myanmar began using the existing SLM system in order to recognise and protect customary land rights in some way. ${ }^{432}$

The Constitution passed in 2008 also includes provisions which are relevant to the interaction between the SLM and CLM systems. Section 23 obligates the government to enact laws which protect the rights of peasants. This is an important provision with regard to swidden cultivators as customary land claims over swidden land could be included in the rights which the state undertakes to uphold.

(a) Development of unused land

From 1988, the Burmese government started to move towards an economic growth model for agricultural production. ${ }^{433}$ This model focused on market reform and encouraging

\footnotetext{
${ }^{429}$ Saitõ, above n 286, at 394-5.

430 At 394.

${ }^{431}$ Martin J Smith Paradise lost? (Article 19, London, UK, 1994) at ch 10.

432 Woods, above n 3, at 15.

${ }^{433}$ At 5; Brown, above n 7, at 176.
} 
foreign investment. ${ }^{434}$ The primary tool used by the SLORC in order to convert perceived wasteland into cultivated land was the Wasteland Law. This legislation empowered the state to allocate unused land to foreign investors. 435

Fallow swidden land was most vulnerable to re-allocation as it was deemed wasteland. ${ }^{436}$ Accordingly, foreign investors were granted large amounts of swidden land as concessions. ${ }^{437}$ These large concessions caused swidden farmers to move further into and clear upland forests for agricultural use. ${ }^{438}$ Swidden cultivation was not legally recognised as a legitimate use of land. ${ }^{439}$ This was primary because land was not legally able to be left fallow without good reason. ${ }^{440}$ Accordingly, swidden fallows were classified as wastelands which could be re-allocated. This had a profound effect in cease-fire areas in Northern Myanmar. ${ }^{441}$ By 2001, more than 1 million acres of land had been allocated to foreign investors under this law.

The changes in economic and agricultural policy also coincided with the negotiation of cease-fire agreements with various insurgent groups in Myanmar's border areas. Ceasefire agreements accelerated the effects of these policy changes on swidden land. Woods outlines how ceasefires between the state and ethnic insurgents in Northern Myanmar undermined swidden land use as they came under the state agricultural legal system. ${ }^{442}$ Logging concessions, opium crop substitution and the conversion of unused land into agricultural plantations has dramatically altered traditional land use. ${ }^{443}$ Furthermore, both state forces and insurgent groups have granted concessions to foreign investors as a means to raise capital. Land has been confiscated and converted into plantations. ${ }^{444}$ For example, rubber plantations in Kokang region, Northern Myanmar, were swidden land before being confiscated and granted as rubber concessions. 445 State-subsidised agricultural programmes introduced by the SPDC, such as the growth of tea plantations in Chin state,

\footnotetext{
${ }^{434}$ Oberndorf, above n 407, at 3.

435 At 3; Woods, above n 3, at 12-3; Talbott, Waugh and Batson, above n 191, at 120.

436 Oberndorf, above n 407, at 3; Woods, above n 3, at 12-3.

437 Talbott, Waugh and Batson, above n 191, at 120.

${ }^{438}$ Hirsch and Warren, above n 53, at 113-4.

${ }^{439}$ Woods, above n 3, at 37-8; At 14.

${ }^{440}$ Henley, above n 182, at 8.

${ }^{441}$ Woods, above n 331.

442 At 756.

${ }^{443}$ Woods, above n 331.

${ }^{444}$ Kramer and Woods, above n 160, at 74.

445 At 75.
} 
have also undermined traditional land use practices. ${ }^{446}$

Where cease-fire agreements were not reached, ongoing fighting has caused further displacement of ethnic minorities and greater food insecurity. In 1998, the SPDC instructed army personnel that they would no longer be able to provide full rations, and soldiers would need to find alternative means of obtaining food. This was accomplished through confiscating land and food from local villages. ${ }^{447}$

(b) Forestry policy

The economic policy governing forestry in Myanmar during this period was also largely detrimental to CLM systems. Logging concession granted to Thai and Chinese investors along Myanmar's eastern and northern borders affected forestland that was held under CLM systems. ${ }^{448}$ On the other hand, swidden cultivation was perceived negatively as the Myanmar government established areas of protected forests for the purpose of environmental conservation. The government viewed swidden cultivation as both an internal and external threat to these protected areas. ${ }^{449}$ The state's solution has been to sedentarise swiddeners. ${ }^{450}$

However, the 1995 Community Forest Instructions took a small step in the state recognising customary land rights over forested land. Section 5 (e) of the CFI highlighted Forest lands that were traditionally managed by the community as candidates for community forestry. ${ }^{451}$ This was only a partial step in recognising customary land rights over forestland. It did not wholly recognise CLM systems. In particular, swidden cultivation was prohibited in s 19 (e) unless it was used as part of approved agro-forestry techniques. These agro-forestry techniques referred to taungya teak planting developed by the British Colonialists where after clearing and burning a section of land, tree seedlings were interspersed with agricultural crops until the trees grew too large to cultivate crops. 452

\footnotetext{
${ }^{446}$ Mary P Callahan and East-West Center Washington Political authority in Burma's ethnic minority states (East-West Center, Washington, DC, 2007) at 41.

447 (Thailand), above n 189, at 19.

448 Talbott, Waugh and Batson, above n 191, at 120; Woods, above n 331.

${ }^{449}$ Istituto Oikos and BANCA, above n 336.

${ }^{450}$ Bryant, above n 189, at 183.

451 Tint, Springate-Baginski and Mehm, above n 21, at 86.

${ }^{452}$ At 35.
} 


\section{2012 Land Law Reforms}

In 2011, the 2008 Constitution was implemented through the establishment of the Parliament or Hluttaw. Since their inauguration, the two houses of the Hluttaw have been reforming Myanmar's legislation in an attempt to consolidate the legislative framework that spans from Colonial times to the present day. ${ }^{453}$ The current president, Thein Sein, is generally regarded as a reformist president. ${ }^{454}$

2012 was a year of substantial legislative reform. ${ }^{455}$ The OECD Investment Policy Review of Myanmar noted that 11 key pieces of legislation were passed in it. ${ }^{456}$ The Farmland Law 2012 (the Farmland Law) and the Vacant, Fallow and Virgin Land Management Law 2012 (the VFV Law) brought about significant reforms to Myanmar's SLM system.

The process surrounding the introduction of the two laws marked a shift in the government's attitude towards public scrutiny of legislative change. ${ }^{457}$ Along with the extensive debate in both Hluttaw, there was also much debate in the public sphere. The government released a copy of the draft Farmland on 16 September $2011 .{ }^{458}$ Various civil society groups, such as the Land Core Group ${ }^{459}$ were consulted and proposed amendments to the proposed Bills. ${ }^{460}$ Despite notable progress in civil society engagement in the parliamentary process, the government was criticised as not having sufficiently consulted with stakeholders. ${ }^{461}$

\section{(a) English versions}

There are no official English translations for the Farmland Law, the VFV Law or either of their accompanying Rules. However, the UN-Habitat has produced unofficial translations to these documents. Alternative English translations to the Farmland Law and the VFV Law are available on the Myanmar Information Management Unit (MIMU) website. ${ }^{462}$

\footnotetext{
${ }^{453}$ Crouch and Lindsey, above n 7, at 183.

454 Jones, above n 10, at 155.

${ }^{455}$ Crouch and Lindsey, above n 7, at 183.

456 OECD, above n 146, at 26.

${ }^{457}$ Displacement Solutions, above n 13, at 11.

458 "BURMA: Draft land law denies basic rights to farmers" Asian Human Rights Commission.

459 The Land Core Group is a network of local and international NGOs as well as individuals interested in land law and policy reform in Myanmar. They are a part of the broader Food Security Working Group. "Myanmar Food Security Working Group" <http://www.myanmarfswg.org/homepage/fullpost/land-coregroup1>.

${ }^{460}$ Displacement Solutions, above n 13, at 11.

461 Transnational Institute “Access Denied” [2013] Burma Policy Briefing no 11 at 2.

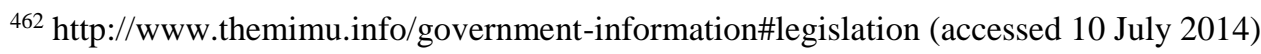


Analysis of the legislation is based on these unofficial translations along with secondary sources containing references to them.

Mistakes within the unofficial English translations are predominantly grammatical. However, grammatical errors may sometimes have significant bearing on the meaning of various provisions. For example, in the Burmese version of the VFV Rules, the phrases "rural farmers" and "families" appear only once in the plural and elsewhere in the singular. Whereas, in the English translation, they appear twice both in the plural, twice both in the singular and once a mixture of singular and plural. The English translation suggests that a group of families or farmers may be able to collectively own land under the specific category for rural farmers and families. However, the Burmese original does not support this assertion.

The UN-Habitat translation of section 3 (a) of the Farmland Law also omits "taungya land" from the list of agricultural land categories defined as "Farmland". The phrase "taungya land" is included in the MIMU translations as well as specifically mentioned by several secondary sources. ${ }^{463}$ After reviewing the original Burmese legislation, the author also identified the omitted phrase. The omission of "taungya land" in the UN-Habitat English translation of s 3 (a) of the Farmland Law is therefore a typographical error. This is important, as swidden land may be included in the meaning of taungya and thereby come under the Farmland Law. The meaning of taungya in the definition section will be discussed below.

$1 \quad$ Farmland Law 2012 - Overview

The Farmland Law repealed and replaced the legislation which had formed the basis of Myanmar's land tenure system for more than half a century. On its enactment into law, the Land Nationalisation Act 1953 and the Disposal of Tenancies Law 1963 along with the Peasant's Rights Protection Law 1963 were removed from Myanmar's statute books. 464

The Farmland Law empowers the Ministry of Agriculture and Irrigation (MoAI), with government approval, to issue rules and regulations deemed necessary in order to carry out the provisions of the Farmland Law. ${ }^{465}$ The Farmland Rules 2012 were enacted pursuant to this delegated authority. ${ }^{466}$

In some aspects, the reformed SLM system is similar to those prior to 2012. It

\footnotetext{
${ }^{463}$ Duncan Macqueen Advancing forest-farm producer groups in Myanmar within market-led community forestry: Report of an advisory mission (IIED, 2013) at 14; Oberndorf, above $\mathrm{n} 407$, at 8; United States Agency for International Development USAID Country Profile, Property Rights and Resource Governance: Burma (USAID, 2013) at 11.

${ }^{464}$ Farmland Law 2012 (Myanmar), s 43.

${ }^{465}$ Farmland Rules 2012 (Myanmar), subs 42(a).

${ }^{466}$ Farmland Rules.
} 
maintains the foundational aspects of Burmese land law that have been a part of all three of Myanmar's Constitutions since 1947. Firstly, the State is the owner of all land and, secondly, farmers may obtain usufruct land rights in order to cultivate land. ${ }^{467}$ It establishes bureaucratic bodies to administer the land rights established pursuant to this legislation. These entities are similar to previous inceptions of state administration. Also, the state continues to exercise a level of control over how agricultural land is utilised.

However, in other aspects, the Farmland Law instigates a significant shift in Myanmar's SLM system towards greater commodification. It inaugurates a system of Land Use Certificates (LUCs) which may be bought, sold, gifted and mortgaged. These activities had been prohibited under the pre-2012 SLM system.

(b) Continuity with previous legislation - administrative bodies

The Law also establishes a hierarchy state administration bodies to manage agricultural land. These are called Farmland Management Bodies (FMBs). ${ }^{468}$ They range from the Central FMB down to respective Regional/State, District, Township and Ward/Village Tract FMBs. ${ }^{469}$ These bodies are similar to the Village Land Committees established under the Land Nationalisation Act 1953, which became the village Security Administrative Committee in 1962 and was later subsumed into the People's Councils. ${ }^{470}$ Section 17 outlines the role of the Central FMB and empowers it to delegate certain aspects of its role to subordinate, localised FMBs. FMBs are composed of members from various government departments. ${ }^{471}$

Although the Farmland Law allows slightly more freedom in crop choice, it maintains restrictions on and control of the use of agricultural land. Section 12 lists the obligations attached to LUCs. Farmers must cultivate land in accordance with the Farmland Law ${ }^{472}$ and land must not be cultivated without the permission of the relevant FMB. ${ }^{473}$ Specifically, farmers are prohibited from changing their crop without permission or using the land for a non-agricultural purpose. ${ }^{474}$ However, Baver et al found this is not occurring

\footnotetext{
${ }^{467}$ Farmland Law 2012 (Myanmar), subs 3(d).

${ }^{468}$ Also known as Farmland Administrative Bodies, (FABs) Baver and others, above n 136.

${ }^{469}$ Farmland Law, s 15 and 16.

470 Than, above n 291, at 80 .

${ }^{471}$ Baver and others, above n 136, at 164.

${ }^{472}$ Farmland Law, subs 12(a).

${ }^{473}$ Farmland Law 2012 (Myanmar), subs 12(f).

${ }^{474}$ Farmland Law, subs 12(g) and (h).
} 
in practice. ${ }^{475}$ The land is also prohibited from being left fallow without good cause. ${ }^{476}$ Farmers must pay relevant taxes in relation to the land ${ }^{477}$ and register activities, such as selling, leasing, gifting and borrowing against farmland with the relevant FMB. However, farmers are prohibited from undertaking these activities while the farmland is disputed or while awaiting the issuance of an LUC. ${ }^{478}$ State permission is required (by the Foreign Investments Commission (FIC)) if any of these activities involve a non-Burmese citizen or an organisation with foreign citizens in it. ${ }^{479}$ Collateral may only be raised for agricultural work ${ }^{480}$ and only obtained through a government bank or authorised bank. ${ }^{481}$ Rules 55-57 of the Farmland Rules empower the wards/village tract FMB to supervise compliance with these conditions.

(c) Legislative changes - Land Use Certificates

The most dramatic reform included within the Farmland Law is the introduction of Land Use Certificates (LUCs). Farmers must be granted permission by the local FMB in order to cultivate farmland. ${ }^{482}$ This permission is given in the form of a Land Use Certificate (LUC). Sections 6-8 list the individuals and entities that may be granted a LUC. Farmers with existing land use rights are able to obtain land-use certificates. ${ }^{483}$ The system removes the restrictions on buying, selling, transferring, gifting and mortgaging land which were in place under the Land Nationalisation Act 1953. Section 8 allows LUCs to be granted to individuals who have bought, exchanged, inherited or been gifted land. Section 9 then outlines the rights attached to LUCs. The Farmland Rules ${ }^{484}$ detail how applications for LUCs are to be made.

2 Virgin, Fallow and Vacant Land Management Law 2012 - Overview

The Virgin, Fallow and Vacant Land Management Law 2012 (VFV Law) is the most recent piece of legislation that deals with uncultivated land in Myanmar. Like the Farmland Laws, subs 34(a) of the VFV Law empowers the MoAI to enact rules and regulations in order to

\footnotetext{
475 Baver and others, above n 136, at 71.

${ }^{476}$ Farmland Law 2012 (Myanmar), subs 12(i).

${ }^{477}$ Farmland Law, subs 12(b).

${ }^{478}$ Farmland Law, subs 12(j).

${ }^{479}$ Farmland Law, s 14.

${ }^{480}$ Farmland Law, subs 12(d).

${ }^{481}$ Farmland Law, subs 12(e).

482 Farmland Law, subs 12(f).

${ }^{483}$ Section 6 (a) (ii) declares the head or members of households who legally held and worked the farmland, in accordance with the existing laws at that time, prior to the enactment of the Farmland Law as eligible to receive LUCs. Farmland Law.

${ }^{484}$ Farmland Rules 2012 (Myanmar), p r 3-46.
} 
undertake the provisions of the law. The VFV Rules 2012 were issued pursuant to this power.

The VFV Law reiterates the government policy that uncultivated land should be used productively. ${ }^{485}$ The 2012 law follows a similar pattern to the Duties and Rights of the Central Committee for the Management of Culturable Land, Fallow Land and Waste Land 1991 ("Wasteland Law"). It replaced the Central Committee for the Management of Culturable Land, Fallow Land and Waste Land with the Central Committee for the Management of Vacant, Fallow and Virgin Lands ("CCML"). ${ }^{486}$ The CCML is able to exercise broad discretionary power within the parameters of the governing Act and Rules. These powers are to allocate land that is deemed unutilised to individuals, but more so organisations who will put it to productive use. Zaw states that Multi-national companies are encouraged to develop these areas. ${ }^{487}$ Like the FMBs, the CCML's members are from a range of government departments: ${ }^{488}$

The CCML may grant use rights to individuals or organisations with regard to land that is deemed Virgin Land or Vacant and Fallow Land. ${ }^{489}$ Virgin land is defined as "new land or other woodland in which cultivation has never been done". It includes land that has been "cancelled legally from reserved forest, grazing land and fish ponds." ${ }^{490}$ Vacant and Fallow land is defined as land which was previously cultivated, but has since been abandoned for any reason. ${ }^{491}$ The length of fallow that may be permitted, if at all, before land can be categorised as fallow and vacant land is not defined anywhere. Furthermore, the term 'abandoned' is not defined elsewhere either.

Like the Wasteland Law, the VFV Law sets different maximum allocation thresholds depending on how the land would be utilised. ${ }^{492}$ However, like the amended Wasteland Procedures, there was a limit of 5,000 acres for perennial or industrial crops until 75 per cent of the allocated land had been developed. After that, up to 50,000 acres of land could be allocated in 5,000 acre parcels. The VFV Laws grant more discretion to central government as more than 5,000 acres can be granted at a time with their approval.

\footnotetext{
485 Oberndorf, above n 407, at 22; Ferguson, above n 360.

486 Vacant, Fallow and Virgin Land Management Law 2012 (Myanmar), s s 3 and 33; United States Agency for International Development, above n 463, at 12; OECD, above n 146, at 318; Henley, above n 182 , at 9.

487 Zaw and others, above n 163, at 323.

488 Baver and others, above n 136, at 164.

489 Vacant, Fallow and Virgin Land Management Law, ss 4-5.

490 Vacant, Fallow and Virgin Land Management Law, subs 2(f).

491 Vacant, Fallow and Virgin Land Management Law, p ubs 2(e); OECD, above n 146, at 321; Oberndorf, above $\mathrm{n} 407$, at 9 .

492 Vacant, Fallow and Virgin Land Management Law, s 10; OECD, above n 183, at 317.
} 
${ }^{493}$ A household may be granted up to 50 acres of VFV land to manage. ${ }^{494}$

Allocated land is granted in the form of usufruct land use rights. Livestock, poultry and aquaculture, perennial plantations and orchards are limited to 30 year land use rights 495 with an additional 30 years if granted permission. ${ }^{496}$ Land rights for seasonal crops may be granted in perpetuity so long as the land user does not breach any conditions of use. ${ }^{497}$ Land may only be used for the permitted purpose. ${ }^{498}$ Individuals and organisations must pay relevant taxes, ${ }^{499}$ complete the proposed development work in 4 years (unless affected by natural disaster or armed conflict) ${ }^{500}$ and meet any other conditions prescribed by the government. 501

(a) Interaction between the Farmland Law and the VFV Law

The Farmland and VFV Laws inter-relate. Sections 8 and 34 of the Farmland Law allow land designated as reclaimed VFV land to be converted into Farmland if crop production is considered stable. ${ }^{502}$

\footnotetext{
493 Vacant, Fallow and Virgin Land Management Law, subs 10(a)(3).

494 Vacant, Fallow and Virgin Land Management Law, subs 10(a)(4); Vacant, Fallow and Virgin Land Management Rules 2012 (Myanmar), p rr 29-35.

495 Vacant, Fallow and Virgin Land Management Law, subs 11(a)(1) and (b).

496 Vacant, Fallow and Virgin Land Management Law, subs 11(c).

497 Vacant, Fallow and Virgin Land Management Law, subs 11(a)(2).

498 Vacant, Fallow and Virgin Land Management Law, subs 16(a).

499 Vacant, Fallow and Virgin Land Management Law, subs 16(d).

${ }^{500}$ Vacant, Fallow and Virgin Land Management Law, subs 16(b).

501 Vacant, Fallow and Virgin Land Management Law, subs 16(e).

502 The application process is noted in rr 35 - 46, Farmland Rules 2012 United States Agency for International Development, above n 463, at 19; Oberndorf, above n 407, at 22.
} 


\section{Interaction between CLM systems and the Farmland Law and VFV Law}

The Farmland Law and VFV Law affect CLM systems in Myanmar. However, the extent to which they do is unclear. The primary issue with the interaction between the Farmland Law and VFV Law and customary land use rights is the legislation's lack of clarity. The level of interaction between these mechanisms is therefore uncertain. There are three specific areas of uncertainty where the current SLM system interacts with CLM systems. They are: firstly, how land under customary tenure is identified; secondly, how communally-held land is recognised; and thirdly, what swidden activities are legally permitted.

\section{$1 \quad$ Integration of customary land rights into the SLM system}

Swidden land in Myanmar is primarily managed by customary law. However, none of the provisions in the Farmland, VFV Law and their subsidiary rules explicitly mention customary land rights. The non-compatibility of customary law with the current legislative framework in Myanmar is a significant issue. ${ }^{503}$

Land titles are registered through the SLRD. However, formalised titles for swidden farmers are rare, if not non-existent. Land in upland areas of Myanmar is not registered with the government. ${ }^{504}$ The 2012 LIFT Baseline Survey Report noted that land claimed as owned was often not formally registered by the government. ${ }^{505}$ In this survey, land ownership was given as wider definition as possible whether formal or informal. ${ }^{506}$ The note reveals both the diversity of types of landholding in Myanmar as well the discrepancies between official records and the unofficial reality.

(a) Applications for Farmland

Subsection 6(a)(ii) of the Farmland Law states that LUCs may be granted to the:

Head of the household (or) a member of the household (or) guardian who [was] legally holding and working the land in accordance with existing land law, before this law [was] enacted.

Also, sub-rule 3(d) of the Farmland Rules contains a similar provision, whereby someone who is "working legally on the farm as per the existing law before the farmland law has come into force" is eligible to apply for an LUC.

This section appears to recognise that holders of existing land use rights are eligible

\footnotetext{
${ }^{503}$ Displacement Solutions, above n 13, at 22; Henley, above n 182, at 10.

504 OECD, above n 146, at 292.

${ }^{505}$ Livelihoods and Food Security Trust Fund "LIFT Baseline Survey Report" (July 2012) <http://archive.liftfund.net/downloads/LIFT\%20Baseline\%20Survey\%20Report\%20-\%20July\%202012.pdf> at 35-6.

${ }^{506}$ At 107.
} 
to be granted LUCs. Such existing land use rights could include customary land rights. However, as customary land rights have not been fully recognised under pre-2012 legislation, it appears that not all swidden land could be included in this provision.

(b) Applications for VFV Land

In applications for grants of VFV land, there is no specific requirement to assess whether there are underlying claims to the land. The closest that the government authorities come to assessing underlying customary title this is that the Township Department Office must identify whether the VFV land is currently being utilised or whether there is encroachment onto it. ${ }^{507}$ There is nothing in the provisions which defines what it means to be a "holder currently utilizing the land". Because swidden cultivators' lands are not generally registered and it is frequently left in long-term rotational fallow, it is possible that they would not come under this provision.

The other way authorities may be notified of existing land claims prior to allocating VFV land is through sub-r 9(b) where the public may raise objections to applications to cultivate and utilise VFV land. Despite having provisions which potentially alert authorities to underlying customary land claims, there are no provisions preventing allocations of VFV land where they do exist. The recognition of customary land rights in applications for VFV land grants is weak.

(c) Existing grants of VFV Land

Section 25 of the VFV Law and $r 52$ of the VFV Rules direct the CCML to take action if pre-existing land rights are discovered in relation to land that has been granted to other land users as VFV land. 508

The pre-existing land use rights here include those which are not registered ${ }^{509}$ and therefore could include customary land rights. This shows that the government may recognise customary land rights. However, it also reveals that these rights are considered inferior to the rights granted under the VFV Law. This is because the discovery of such rights does not displace VFV land grants. Rather, the CCML is empowered with broad discretion power to seek a vague resolution to the dispute.

The Myanmar government does not have a positive history regarding the recognition of underlying customary land claims in large-scale land allocations. ${ }^{510} \mathrm{~A}$ Displacement Solutions report suggests that even obtaining an LUC does not necessarily

\footnotetext{
${ }^{507}$ Vacant, Fallow and Virgin Land Management Rules 2012 (Myanmar), p r 10(b)(2) and (3).

${ }^{508}$ Oberndorf, above n 407, at 22.

509 OECD, above n 146, at 293; Oberndorf, above n 407, at 22.

${ }^{510}$ Oberndorf, above n 407, at 14.
} 
protect the land holder from eviction, ${ }^{511}$ much less if the individual or group are only able to rely on customary land rights. Willis comments that those who occupy customarily owned lands which have been granted to other land users are called "squatters." 512 Furthermore, s 27 of the VFV Law makes encroachment onto land granted under the law an offence. ${ }^{513}$ Sekine highlights problems with the recognition of underlying customary land rights under the Farmland Law in Dawei, Tanintharyi Division, in Southern Myanmar, citing corruption, manipulation, poor administration and delays. ${ }^{514}$

Ambiguous or non-existent definitions and customary land rights spread over different land categories limit the possibility of completely recognising customary land rights through this process.

(d) Progress towards greater recognition of customary land use rights

There is recognition that there is a lack of research on customary land rights currently practiced in Myanmar. ${ }^{515}$ Leading up to the release of the Draft NLUP, there were calls from civil society for greater integration of customary land law into Myanmar's statutory framework and the resolution of customary land-holding before granting land as concessions. ${ }^{516}$ The Draft NLUP explicitly recognises customary land tenure and land use rights. ${ }^{517}$ This represents considerable progress from the 2012 law reforms. Section 72 temporarily suspends granting of land concessions over which there are customary land claims. It appears as though such concessions will be suspended until the land has been reclassified.

Under the Farmland and VFV Laws and their Rules, customary land rights are implicitly recognised. However, these rights are very weak and uncertain. The Draft NLUP dramatically alters this position through explicitly recognizing customary land use rights. It also begins to address the fraught issue of land concessions that have been granted over

\footnotetext{
${ }^{511}$ Displacement Solutions, above n 13, at 7.

512 Nathan Willis "Land disputes and the ongoing development of the substantive rule of law in Myanmar (Burma)" [2013] at 890.

513 The maximum sentence for encroachment is 2 years imprisonment and/or MMK 500,000. Vacant, Fallow and Virgin Land Management Law 2012 (Myanmar), s 27.

514 Yukari Sekine "Globalization and local land governance: Mechanisms of confiscation and contentious politics in Myanmar's Dawei Special Economic zone area" (paper presented to Environmental Governance and Development Policy in Southeast Asia, Tokyo, Japan, 10 January 2015) at 14.

${ }^{515}$ Food Security Working Group, above n 41, at 17.

516 Food Security Working Group Submission for the Revisions to the Draft Myanmar Farmers Rights Protection Law (Food Security Working Group, 2013) at 12.

517 Government of the Republic of the Union of Myanmar Land Use Allocation and Scrutinizing Committee, above n 31, at Part VII, ss 68-77; Letter from Roy Prostermann and Laura Eshbach (Landesa) and Darryl Vhugen (Land Tenure Investment Consultant) to Those concerned with land tenure in Myanmar regarding Commentary on the Draft National Land Use Policy (28 October 2014) at 7; Lwin, above n 32.
} 
customarily managed land left in long-term rotational fallow through temporarily suspending future grants.

For CLM systems governing swidden land to be more adequately recognised, there are three specific areas which must be addressed within the current legal framework.

\section{Identification of customarily held swidden land}

The first issue deals with how swidden land is defined and identified under the current legislation.

(a) The definition of 'farmland'

It is unclear whether swidden land can be classified as farmland under the Farmland Law. The definition of 'farmland' in s 3(a), includes taungya. This is the generic Burmese word for hillside cultivation. Of the land categories listed in s 3(a), only "paddy field" and "alluvial land" are defined further. ${ }^{518}$ Taungya is mentioned once more in the Farmland Law ${ }^{519}$ and once in the Farmland Rules. ${ }^{520}$ However, in these contexts, it is used alongside "shwe pyaung". In these appearances, it therefore refers more specifically to swidden agriculture.

The reference to swidden cultivation in section 17 (i) lists that one of the duties of the Central FMB is: "to give guidance and control in respect of shifting Taungya cultivation." Rule 116 of the Rules appears to clarify what this guidance and control entails. The central FMB is to effectively encourage the transition from swidden cultivation to terraced cultivation in upland areas. This is hoped to lead to the ultimate elimination of swidden agriculture from Myanmar. ${ }^{521}$

(b) Arguments against swidden cultivation being included as 'farmland'

Oberndorf surmises that taungya in section 3(a) specifically refers to upland cultivation without a rotational fallow. ${ }^{522}$ The USAID report on property rights and land governance in Myanmar also supports this view. They argue that even though the definition of Farmland includes taungya, the MoAI interprets this as only permanent cultivation. ${ }^{523}$ In correspondence with USAID, they have said that the definition of taungya is unclear.

\footnotetext{
518 Farmland Law 2012 (Myanmar), subss 3(b) and (c) respectively; Food Security Working Group, above n 516, at 11 .

519 Farmland Law, s 17 (i).

${ }^{520}$ Farmland Rules 2012 (Myanmar), r 116.

${ }^{521}$ OECD, above n 146, at 321.

522 Oberndorf, above n 407, at 8.

${ }^{523}$ United States Agency for International Development, above n 463, at 20.
} 
However, it does not appear to recognise swidden cultivation. ${ }^{524}$

The prohibition in s 12(i) against leaving farmland fallow without good reason could be seen as supporting this view. This is because leaving land fallow is an integral part of swidden cultivation. The further references to swidden cultivation in the Farmland Law and Rules could also be interpreted as excluding it from the taungya land category. Rule 116 treats swidden as a problem which will be solved as swidden land is converted into permanent terraced plots. It could be seen that as swidden land is converted into permanent upland terraces, it is then able to be categorised as 'farmland'.

(c) Arguments in favour of swidden cultivation being included as 'farmland'

However, it could also be argued that because taungya in s 3(a) refers to the larger category of upland cultivation, it includes swidden cultivation. Furthermore, leaving a field fallow in order to maintain sustainable soil nutrients could be regarded as a 'good reason' for not actively cultivating the land under s 12(i). The further references to the central FMB's oversight of swidden land could be interpreted as reflecting their jurisdiction over all farmland, including swidden cultivation. In correspondence with UN-Habitat, the organisation managing the practical implementation of land titling and registration, land may be registered and farmers granted an LUC irrespective of farming method. Therefore, as long as swidden land is categorised as agricultural land and cadastral maps have been issued for the land in question, swidden farmers may be granted an LUC for the plot of land. 525

(d) Practical realities regarding swidden land

However, in practice, there are a number of examples which suggest that Myanmar authorities do not consider swidden land to be farmland. Firstly, it appears that land used for swidden cultivation is not able to be registered under the Farmland Law. ${ }^{526}$ It would be a misnomer if farmers were required to register swidden land as farmland, in order to legally cultivate it, but the FMBs and SLRD would not in fact register land used in this way. This suggests that the authorities do not permit the registration of swidden land in order to receive LUCs, as they do not recognise swidden fallows as farmland.

Secondly, a recent JICA report notes that swidden cultivation is still permitted in

\footnotetext{
${ }^{524}$ Email from Jeremy A Green (Program Analyst, USAID Land Tenure and Property Rights Portal) to Jim Ennion regarding the USAID Country Profile - Property Rights and Resource Governance - Burma (25 June 2014)

525 Email from Ian Lloyd (Director, Land Equity International) to Jim Ennion regarding the Land Administration and Management Programme (LAMP) for Myanmar (10 October 2014).

${ }^{526}$ OECD, above n 146, at 311; Macqueen, above n 463, at 22.
} 
mountainous areas. ${ }^{527}$ If swidden agriculture was perceived as farmland, there would be pressure for this land to be registered as such. Rather, it appears that the state allows swidden land to be cultivated traditionally. However, once land has been sufficiently developed in order to become permanent cultivation, it may become classified as farmland.

Thirdly, the Myanmar government categorises swidden land across many different land categories. The official definition of shifting cultivation for statistical purposes is limited to forested and mountain areas. ${ }^{528}$ For example, in Myanmar's 2005 Forest Resource Assessment, it was found that swidden cultivation affected $119,193 \mathrm{~km}^{2}$ of forest land, which equals 17.6 per cent of total land area. ${ }^{529}$ Tint et al cite that Myanmar's 2010 Forest Resource Assessment records swidden cultivation affecting 201,125km², or 29.73 per cent of forest land. ${ }^{530}$ However, the statistical definition of agricultural land also includes some shifting cultivation land. ${ }^{531}$ This information could support either conclusion. It could show that most swidden land is not considered farmland. However, on the other hand, it could show that swidden land classified as agricultural could be registered as farmland.

(e) Conclusion

There are arguments for and against whether swidden cultivation is included in the term 'taungya' in the definition of farmland. The conflict between sources which describe how the legislation is implemented further convolutes the situation. Notwithstanding, the issue is not clearly dealt with by the Farmland Law and accompanying Rules. Recognising swidden cultivation as a legal land use category has been specifically recommended in submission for further land law reform. ${ }^{532}$

(f) Swidden defined as 'Vacant and Fallow' Land

The issue of the identification of swidden land is also relevant to the VFV Law. One of the key problems in the VFV Law is whether swidden land is considered fallow and vacant land.

The definition of "vacant and fallow" land in section 2(e) is very broad. Land need only be previously cultivated then left uncultivated before it may be deemed vacant and fallow. This is a significant issue for swidden land, as leaving land uncultivated in long-

527 Japan International Cooperation Agency and others Preparatory Survey for the Integrated Regional Development for Ethnic Minorities in the South-East Myanmar - Final Report (EI JR 13-199 2013) at 3-31.

${ }^{528}$ Forestry Department, Food and Agriculture Organization of the United Nations Global Forest Resources Assessment 2010 Country Report: Myanmar (FRA2010/141 2010) at 6.

${ }^{529}$ Union of Myanmar, Ministry of Forestry Third National Report to the UNCCD (2006) at 34.

${ }^{530}$ Tint and others, above $\mathrm{n} 334$, at 1.

${ }^{531}$ Forestry Department, Food and Agriculture Organization of the United Nations, above n 528, at 6.

${ }^{532}$ Food Security Working Group, above n 516, at 11. 
term fallow is an integral part of swiddening. However, there are no further definitions within the Law or Regulations to understand where swidden land lies on the continuum between cultivated land and abandoned land.

While Government policy does not support long-term swidden fallows, they allow for shorter fallows in order to enable soil to maintain nutrients. This is because fertilisers are expensive and not always widely available in Myanmar. ${ }^{533}$ For statistical purposes, the Myanmar government defines "fallow" as "land left idle for at least one agricultural year but not beyond five years for the purpose of regaining its fertility." ${ }^{534}$ Under this definition, swidden land would not be categorised as 'fallow.' This is because swidden land requires much longer fallows between cropping in order to replenish nutrients. ${ }^{535}$ Sub-rule 10(b)(i) instructs the Township Department Office to ascertain whether the land which is applied for is in fact VFV land. As there is no definition as to when abandoned cultivated land becomes VFV land, it is left to the Department Office's discretion to make this judgment. Any land that is currently being cultivated by swiddeners would not be considered VFV land. However, it is unclear how many years land would need to be left in fallow in order to become VFV Land.

Although not all swidden land will be considered vacant and fallow land, there is agreement amongst commentators that a significant proportion of it will be. For example, Oberndorf states that due to this definition, many swidden areas could be categorised as "vacant and fallow". 536 Macqueen agrees and states that much of the swidden land in Chin State is considered to be Public Forest Land or Vacant and Fallow Land. ${ }^{537}$ The status of swidden land as vacant and fallow makes it very vulnerable to being reallocated to other parties such as foreign investors.

(g) Conclusion

The identification and classification of land affected by swidden cultivation is unclear under the current legal framework. It had been hoped that a new National Land Use Policy would provide clarity with regard to the formal identification and recognition of swidden agriculture. ${ }^{538}$ The Draft National Land Use Policy has since been released. It specifically

\footnotetext{
533 OECD, above n 146, at 295.

${ }^{534}$ Castano, above n 330, at 68.

535 Alain Atangana and others Tropical agroforestry (Springer, 2014) at 71-3; Macqueen, above n 463, at 15; Mon and others, above n 150, at 195.

536 Oberndorf, above n 407, at 9.

${ }^{537}$ Macqueen, above n 463, at 14.

${ }^{538}$ Leckie and Simperingham, above n 266, at 44; Email from Jeremy A Green (Program Analyst, USAID Land Tenure and Property Rights Portal) to Jim Ennion regarding the USAID Country Profile - Property Rights and Resource Governance - Burma (25 June 2014)
} 
recommends the reclassification of swidden land as it is currently spread across different land categories. ${ }^{539}$ This will help overcome the ambiguity faced by swidden farmers who have to follow different procedures for different categories of land in order for their land to be recognised by the SLM. However, the Draft NLUP does not provide a definition of swidden cultivation or use any terms which specifically refer to swidden cultivation. Rather, it continues to use the generic word taungya such as 'taungya farming' or 'alternative farming method' $540 \& 541$ or slightly more specific phrases, such as 'rotating taungyas,' $542 \& 543$ and 'traditional alternative taungya system.' 544 Swidden cultivation could also be included in more generalised phrases, such as 'traditional land use practices' 545 and 'lands cultivated by traditional methods' 546

The draft NLUP is more explicit in identifying and recognising swidden cultivation than the Farmland Law or VFV Law. However, the lack of a clear definition and the multiplicity of terminology add confusion and obscurity. ${ }^{547}$ The issue of identifying swidden land under customary tenure has been improved under the draft NLUP, but not completely resolved.

\section{$3 \quad$ Management of swidden land (whether communally-held land is recognised)}

Both the Farmland Law and the VFV Law appear ambiguous with regard to communal or collective ownership of property. This is despite communal ownership of land being widespread in upland areas. ${ }^{548}$ Commentators have either stated that the new laws do not recognise communal land rights ${ }^{549}$ or have recommended that this type of land tenure ought to be explicitly enacted in legislation. ${ }^{550}$

\footnotetext{
539 Section 72, Government of the Republic of the Union of Myanmar Land Use Allocation and Scrutinizing Committee, above n 30.

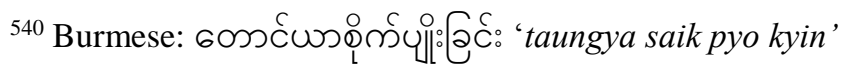

${ }^{541}$ Government of the Republic of the Union of Myanmar Land Use Allocation and Scrutinizing Committee, above $\mathrm{n} 30$, at ss 57 and 74 .

542 Burmese: 600 ćcuswp:ईç 'taungya mya hnin.'

${ }^{543}$ Government of the Republic of the Union of Myanmar Land Use Allocation and Scrutinizing Committee, above $\mathrm{n} 30$, at subs 33(d).

544 At s 75.

545 At s 68, 70(a) and (b).

${ }^{546}$ At ss s 34(d), 61(b) and 71.

547 TNI Myanmar Programme and TNI Agrarian Justice Programme, above n 31, at 11.

${ }^{548}$ Food Security Working Group, above n 41, at 17.

549 Displacement Solutions Land Rights and Mine Action in Myanmar (Displacement Solutions, 2014) at 17.

${ }^{550}$ Food Security Working Group, above n 516, at 11; OECD, above n 146, at 11; Oberndorf, above n 407 , at III and 26.
} 
(a) In the Farmland Law and Rules

The Farmland Law and Rules outline that the two types of entities eligible to be granted LUCs are persons or organisations. ${ }^{551}$

(b) Eligible persons

Subsection 6(a) of the Farmland Law lists those who are considered eligible persons. Of this list of eligible persons, only the term "agricultural household" in subs 6(a)(i) appears to incorporate communal ownership of land in any way. The term "agricultural household" is defined in subs 3(f) as "a group of persons related by blood or marriage, living together as a household [...] whose head [is] an agriculturist." This meaning does appear to allow communal ownership of LUCs. However, this form of communal tenure is restrictive. It extends only to those related by blood or marriage, who are living together as a household. This would prevent communal ownership extending beyond a single household into a community comprising of a collection of households. The term "agricultural household" could therefore exclude many forms of collective management of swidden land. ${ }^{552}$

The list of eligible citizens in $r 3$ of the Farmland Rules mirrors the provisions in subs 6(a) of the Farmland Law with several additions: Subsections (i), (ii) and (iii) appear to correspond respectively to sub-rules (a), (b) and (d). The requirements that an applicant be a Myanmar citizen ${ }^{553}$ of more than 18 years old ${ }^{554}$ are included in $\mathrm{r} 3$ as applicable to all potentially eligible applicants. Sub-rule (c) appears to allow collectively held land, however, like subsection (i), this is limited only to a family living in the same house and related by blood or marriage.

(c) Eligible organisations

The Land Core Group (LCG) has undertaken a research project which attempted to register communities in Northern Chin State as an organisation. A new Association Law under which groups would be incorporated was passed in 2014. However, the implementing rules to enable associations to be formed have not been issued. Because of this, it has not been possible to ascertain whether this process is feasible. Once the implementing rules for the Association Law are issued, it is still uncertain whether the process would work. ${ }^{555}$

(d) In the VFV Law and Rules

The VFV Law and Rules also contain criteria for those who are able to obtain grants of

\footnotetext{
${ }^{551}$ Farmland Law 2012 (Myanmar), ss 6 and 7; Farmland Rules 2012 (Myanmar), rr 3 and 4.

552 Food Security Working Group, above n 41, at 17.

${ }^{553}$ Farmland Law, subs 6(a)(v).

${ }^{554}$ Farmland Law, subs 6(a)(iv).

555 Glenn Hunt "Mapping of rotational and fallow taungya lands in Chin and Shan States" (ECODEV Customary Tenure Mapping Workshop, Yangon, 4 February 2015).
} 
VFV land in order to cultivate or utilise the land. They are listed in s 5 of the VFV Law and is almost identical to the list in the VFV Rules. ${ }^{556}$ However, the most notable change is the addition of a sixth category. Sub-rule 3(f) allows "[r]ural farmers and families who wish to carry out manageable agricultural projects" to apply for grants of VFV land.

In terms of recognising communal land tenure in VFV grants, subsection 5(a) and sub-rule 3(a) allow Myanmar citizen investors to apply for VFV Land. This provision could potentially allow a number of investors to jointly develop VFV land. This interpretation is supported by subsections (d) and (e) enabling joint ventures between Myanmar investors and other parties, such as local NGOs, government departments as well as foreign entities. Such joint ventures would naturally involve more than one investor, although they could also form a single entity, such as a company as their joint venture vehicle. These provisions could potentially allow swidden cultivators to jointly develop land deemed vacant, fallow or virgin under this provision.

(e) Does the procedure for 'rural farmers or families' enable communal tenure?

The addition of sub-rule 3(f) in the VFV Rules allows for rural farmers or families to apply for VFV land grants. ${ }^{557}$ The addition of the $\mathrm{r}$ 3(f) category under the Rules and differentiated application procedure appear to be based on subs 10(1)(a)(iv) of the VFV Law. Subsection 10(1)(a)(iv) enables the Central Committee to delegate granting "rural cultivators and persons" permission to cultivate and utilise up to 50 acres of VFV land to a subordinate departmental office. The alternative procedure for rural farmers and families could enable permission to cultivate and utilise VFV land to be granted more speedily. ${ }^{558}$ The Rules outline the process rural farmers and families may take in order to be granted up to 50 acres of VFV land.

However, it is again unclear to what extent these provisions allow communal landholding. Unlike the Farmland Law, ${ }^{559}$ the terms "rural farmers" and "families" are not further defined. The terms therefore do not necessarily take the restricted meaning contained in the Farmland Law.

\footnotetext{
556 Vacant, Fallow and Virgin Land Management Rules 2012 (Myanmar), r 3.

${ }^{557}$ After examining the original Burmese documents, the relevant portions of subs 10(1)(a)(iv) and sub-r 3(f) are identical. Both begin with the following in Burmese: 6nj:0

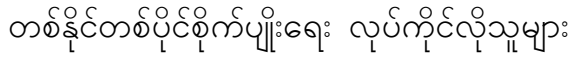

558 It appears from the limited material regarding the VFV Law's legislative history that the VFV Bill originally allowed farmers to cultivate up to 10 acres of VFV Land. However, this was amended to 50 acres by the Pyithu Hluttaw Bill Committee. Myanmar News Agency "Pyithu Hluttaw session continues for 48th day One proposal discussed, information to enlist given, formation of commission submitted, approval for one bill sought" (17 November 2011) <http://www.burmalibrary.org/docs12/PH-NLM2011-11-17.pdf>.

${ }^{559}$ Vacant, Fallow and Virgin Land Management Rules, rr 3-21. Farmland Law, subs 3(f).
} 
(f) Whether the VFV Rules allow groups of farmers and rural families to apply for permission to use VFV land

The first question that arises is whether the VFV Rules allow only individual rural farmers and families to apply to use VFV land or whether groups of rural farmers and families may apply. In the English translation of the VFV Rules, it is ambiguous. Applications of this type are referred to 8 times throughout the remainder of the Rules. ${ }^{560}$ In these 8 occurrences, the pair of terms "farmer" and "family" appear five times. In the English translation, they appear twice both in the plural, twice both in the singular and once a mixture of singular and plural. In the other three occasions, the terms "farmer" and "family" are not used, rather more generalised terms are used. This could suggest that groups of rural farmers and families are able to make applications for permission to use VFV land.

However, in the original Burmese version, only sub-r 3(f) uses the plural. All other rules referring to this category of applicants uses the singular. It therefore appears that the ambiguity in the English translation is caused by grammatical error in the translation.

(g) How big is a family?

Although it appears that groups of families could not collaborate and apply for permission to use VFV land, it is unclear how far the term "family" extends. Unlike the Farmland Law, there is nothing within the VFV Law which confines it to those living under the same roof.

Interpretation could be taken from common understandings of rural families within Myanmar. When describing Kachin culture, Leach discusses the term htinggaw, which could mean both those living in the same house, but also those of similar lineage, potentially including relatives up to 5 generations removed. ${ }^{561}$ However, other descriptions of rural family life in Myanmar generally focus on the nuclear family. ${ }^{562}$ Each household within Myanmar is registered with the government. These households are restricted to those living in the same house. The size of land holding is also recorded on a "per household' basis. ${ }^{563}$ Likewise, both the 2012 baseline study and 2013 household survey conducted by LIFT categorised those surveyed by household. ${ }^{564}$

In the absence of a definition of family in the VFV Law, sub 3(f) of the Farmland Law, which limits family members to those living in the same house, would likely be used

\footnotetext{
${ }^{560}$ Vacant, Fallow and Virgin Land Management Rules, rr 15(a) and (b), 21(a) and (b), 26, 30(a), 38(a)(1) and $45(\mathrm{~b})$.

${ }^{561}$ Leach, above n 193, at 73.

562 Okamoto and others, above n 296, at 8; Maung Maung Bibliography and list of Dhammarthat in "Law and custom in Burma and the Burmese Family"; This was even the case in more outlying areas which practice shifting cultivation. Stevenson, above n 191, at 106.

${ }^{563}$ Food Security Working Group, above n 41, at 43.

${ }^{564}$ Livelihoods and Food Security Trust Fund, above n 505, at 10; Livelihoods and Food Security Trust Fund (LIFT) Household Survey 2013 at 32.
} 
to aid interpretation. This is made more likely due to the close relationship between the two pieces of legislation, such as the conversion of VFV land into Farmland. For example, if a 'family' which included relatives not living within the same house received permission to use VFV land pursuant to the VFV Law, then this family applied to convert the VFV land into Farmland, only the land which was cultivated by family members under the same roof could be included in the LUC.

It appears more likely that 'family' in the VFV Law and Rules would be interpreted in the same way as 'farmer household' in the Farmland Law.

(h) How much land does a family require?

Although the context the term 'family' within the VFV Law and Rules favours a more restricted interpretation of the term, the size of land allocations available under the VFV Land and Rules suggest a broader interpretation.

Sub-rule 30(a) limits initial approval of VFV land grants by the Naypyidaw Council, Regional or State task force for rural farmers or families to 10 acres parcels. Myanmar's 2010 agricultural census showed that the average parcel size was 6.34 acres. ${ }^{565}$ However, this figure included all types of land in Myanmar. LIFT surveys showed that the average land holding for households in hilly areas (where swidden agriculture is predominantly practiced) was 3.51 acres in $2012{ }^{566}$ and 3.2 acres in 2013. ${ }^{567}$ These figures should be taken in the light of the wide variety of types of land holding in Myanmar's uplands. For example, they could refer to the land a family is individually allocated as their portion of collectively managed swidden land. In Thein's research of swidden cultivation in Chin State, the size of individual swidden cultivation plots or lopil ranged between 1-5 acres per household. ${ }^{568}$ On the other hand, in Rammohan and Pritchard's analysis of this data with regard to household food security, the authors assessed how factors such as the amount of land holding and region affected food security. ${ }^{569}$ They concluded that households living in upland areas were less likely to be food insecure. However, if they had access to more than 10 acres of land households were significantly less likely to lack food for any months during the year. This means that although the mean and median size of land holding in upland areas is much less than 10 acres, these families could still face food insecurity at certain times of the year. Notwithstanding, this seems to show that even limiting the initial grant of VFV land to 10 acres would not restrict several families collaborating together and

\footnotetext{
565 Castano, above n 330, at 56.

${ }^{566}$ Livelihoods and Food Security Trust Fund, above n 505, at 36.

${ }^{567}$ Livelihoods and Food Security Trust Fund (LIFT), above n 564, at 81.

568 Thein, above $\mathrm{n} 124$, at 19, 23 and 26.

569 Anu Rammohan and Bill Pritchard "The Role of Landholding as a Determinant of Food and Nutrition Insecurity in Rural Myanmar” (2014) 64 World Development 597.
} 
being able to jointly utilise the land.

Sub-rule 30(b) also allows a family to apply for ${ }^{570}$ and be allocated further parcels of 10 acres as long as the development plan for the original 10 acre block has been 75 per cent implemented. Rural farmers and families may be granted up to 50 acres of VFV land. Again, 50 acres represents a large landholding. In the LIFT Baseline Survey, 99 per cent of those surveyed utilised land which was less than 20 acres in size. ${ }^{571}$ Allowing grants of up to 50 acres of land again suggests that relatives living in different houses could collaborate in order to develop and then cultivate this land, as it appears unusual for a single family to hold such a large amount of land.

(i) Conclusion

It is not explicitly clear whether the VFV Law and Rules allow for communal applications and grants of VFV land. However, it would be helpful to clarify this in any further reform of the VFV Law and Rules.

\section{$4 \quad$ Use of swidden land (whether swidden practices are permitted)}

(a) CCML Permission

The largest hurdle would be for the CCML to approve projects to develop VFV land which maintained the status quo of swidden cultivation. As noted in the CCML is a multidepartmental committee. These departments reveal different attitudes and solutions in dealing with swidden cultivation. The MoAI appears to favour swidden cultivators adopting permanent cultivation through upland terracing and other similar projects. ${ }^{572}$ The MoECAF, however, appears to favour more sustainable integration of swiddening into Myanmar's forests. For example, it suggests community forestry and agroforestry as potential solutions. ${ }^{573}$ Despite their differences, both institutions are united in their opposition to swidden cultivation. ${ }^{574}$ Swiddening is viewed as a major cause of forest degradation and other environmental problems. ${ }^{575}$ Although it is also recognised that millions of rural households rely on this form of cultivation and that it cannot be completely eradicated. 576

\footnotetext{
${ }^{570}$ Vacant, Fallow and Virgin Land Management Rules 2012 (Myanmar), r 27.

${ }^{571}$ Livelihoods and Food Security Trust Fund, above n 505, at 35.

572 Zaw and others, above n 163, at 324-5.

${ }^{573}$ Union of Myanmar, Ministry of Forestry, above n 529, at 28.

${ }^{574}$ At 27-9; Baver and others, above n 136, at 65; The Land Core Group of the Food Security Working Group The Role of Land Tenure Security for Smallholder Farmers in National Development: a policy discussion by the Land Core Group of the Food Security Working Group at 10.

${ }^{575}$ Myint, above n 16, at 20; Union of Myanmar, Ministry of Forestry, above n 529, at 19.

${ }^{576}$ Union of Myanmar, Ministry of Forestry, above n 529, at 19.
} 
However, even if the CCML approved VFV land to be cultivated using traditional swidden practices, it is then questionable whether swiddening could be sustained under the legislative constraints of the VFV Law and Rules.

The VFV Law and Rules emphasise the need to utilise VFV land and complete projects within certain time periods. Subsection 16(b) of the VFV Law states that projects must be completed within 4 years. Subsections $22(\mathrm{~d})$ as well as s 21 empower the government to revoke land use rights over land in which projects have not been completed in the prescribed time. In the VFV Rules, sub-rr 45(a) and (b) reiterate the need for the holders of VFV land use rights to complete the approved project within the prescribed time. The two sub-rules differentiate between regular applications and those of less than 50 acres by rural farmers or families. Sub-rule 45(a) prescribes the percentages to which regular projects ought to be complete after each year. After 4 years, the entire project should be completed. Sub-rule 45(b) stipulates that rural farmers and families ought to complete their projects within 2 years. Sub-rule 51(b) applies the revocation powers of the VFV Law to land that has not been utilised after the respective 2 or 4 year period. Although it is not critical for the land to be currently utilised, there must be evidence that all the land has been utilised at some time since the right to cultivate and utilise the land was granted. ${ }^{577}$ Subrule 30 (b) allows further 10 acre grants of land to rural farmers and families only if 75 per cent of the project on the original allocation of land has been implemented.

If several households were granted 10 acres of VFV land to carry out swidden cultivation, it may be possible for them to sustain a subsistence lifestyle. Swidden cultivation is more successful where collective labour may be used to carry out labourintensive activities at certain times of the year. However, it may be possible to maintain a swidden plot of 10 acres between several households. Hypothetically, households could utilise the 10 acres over the allowable 2 years by cultivating 5 acres per year. If permitted, they could then apply for further allocations of 10 acres and continue to cultivate these 5 acres per year. Once they had reached 50 acres of land, they could return to the original 10 acre allocation as it would have lain fallow for 10 years, sufficient time for the soil to be replenished.

(b) Customary land rights being formally recognised as farmland

Oberndorf notes that s 25 of the VFV Law and r 52 of the VFV Rules along with ss 8 and 34 in the Farmland Law could allow for the formal recognition of existing customary land rights. ${ }^{578}$ Likewise, correspondence with UN-Habitat suggests that these provisions are specifically designed to enable land categorised as forestland, although currently

\footnotetext{
577 Vacant, Fallow and Virgin Land Management Rules 2012 (Myanmar), sub-r 51(c).

${ }^{578}$ Oberndorf, above n 407, at 22.
} 
cultivated, to be used as agricultural land and then converted into farmland. ${ }^{579}$

However, it is unclear whether swiddeners would in fact be granted LUCs in respect of land converted from VFV land use rights into farmland. There are a number of potential barriers to this process. Firstly, land is prohibited from being left fallow without good cause 580 and the length of fallow currently recognised by the Myanmar government is 5 years rather than the 10 or more years needed for swidden cultivation. This could prevent swidden land being able to be considered Farmland in the first place Secondly, VFV land for which land use rights have been granted must have "stable crop production" in order to be considered eligible for conversion to Farmland. ${ }^{581}$ It is therefore unclear whether swidden cultivation would be deemed "stable crop production." If this term means permanent cultivation the capital investment required to achieve this would put this option out of reach to subsistence swiddeners. It would also intrinsically change the nature of the type of cultivation. Thirdly, the Myanmar government has also displayed negative attitudes towards swidden cultivation. ${ }^{582}$ The policy direction taken by the government has been to encourage permanent cultivation wherever possible. ${ }^{583}$

(c) Conclusion

As shown above, it is highly unlikely that government organisations would permit swidden to be practiced on a VFV land grant or that it would be a viable operation. It also appears that obtaining a LUC in respect of this land would at the least be very difficult, if not impossible. ${ }^{584}$

\footnotetext{
${ }^{579}$ Email from "Information about: Land Administration and Management Programme (LAMP) for Myanmar - jimandnitika@gmail.com - Gmail.”

${ }^{580}$ Farmland Law 2012 (Myanmar), subs 12(i).

${ }^{581}$ Farmland Law, s 34; Farmland Rules 2012 (Myanmar), r 35.

${ }^{582}$ Farmland Rules, p r 116; Zaw and others, above n 163, at 324-325.

583 Baver and others, above n 136, at 65.

${ }^{584}$ Macqueen, above n 463, at 22.
} 


\section{Formalisation of customary land use rights}

The objective of this thesis is to propose reforms which will enable CLM systems to be recognised as comprehensively as possible within the SLM system. The term used to describe the integration of CLM systems into the SLM system is formalisation. Hall et al define formalisation as "the recognition and inscription by the state of rights and conditions of access within specific boundaries." 585 If customary land use rights associated with swidden land are to receive greater recognition and protection in Myanmar, they will need to be formalised in some way. ${ }^{586}$ Formalisation can be framed in relation to the access model. It enables the SLM and CLM mechanisms to complement rather than conflict with each other.

In general, if formalisation involves the establishment of legal structures and processes, they should be as closely aligned as possible to existing customary practices. ${ }^{587}$ The existing CLM system currently manages the complex assortment of land rights. A formalised system should make use of these localised understandings and processes. ${ }^{588}$ If formalisation does not take into account existing practices, it can undermine them and cause greater tenure insecurity as there is less reason to cooperate as well as uncertainty as to which system operates in a particular area. ${ }^{589}$ The formalised SLM system should also allow for change rather than inflexibly concreting customary land use rights in fixed processes. ${ }^{590}$

Sturgeon and Sikor highlight the existence of 'fuzziness' within tenure relations in post-socialist Southeast Asian countries. ${ }^{591}$ This fuzziness arises from conflict between the SLM and CLM mechanisms of access as well as other factors influencing actors' access to land. It can allow soft enforcement of tenure rights, ${ }^{592}$ but more frequently enables abuse from those with greater power. ${ }^{593}$

If both the SLM and CLM systems complement each other, it prevents the creation

\footnotetext{
585 Hall, Hirsch and Li, above n 52.

586 Woods, above n 3 , at 3 .

${ }^{587}$ Daniel Fitzpatrick “"Best Practice’ Options for the Legal Recognition of Customary Tenure” (2005) 36 Development and Change 449 at 471; Klaus Deininger "Land policies and land reform" [2004] World Bank, Washington at 7; Deininger and others, above n 39, at 39-40; Baver and others, above n 136, at 97.

${ }^{588}$ Deininger and others, above n 39, at 29.

589 Michael Trebilcock and Paul-Erik Veel "Property Rights and Development: The Contingent Case for Formalization” (2008) 30 U Pa J Int'l L 397 at 447.

${ }^{590}$ Baver and others, above n 136, at 50; Ellen, above n 2, at 26-27.

591 Sturgeon and Sikor, above n 57.

592 Hall, Hirsch and Li, above n 52, at 12.

${ }^{593}$ Sturgeon and Sikor, above n 57.
} 
of a dual tenure system. ${ }^{594}$ In these situations external circumstances have a greater influence in dictating which actors will gain access to land. Likewise, as state power is extended and the SLM is more comprehensively applied, the power imbedded in the SLM mechanism of access is increased. Unless CLM systems are complementary to the SLM system, they will become correlatively weakened and over-ridden.

(d) Formalisation models

The previous chapter outlined three main issues regarding the recognition of customary land use rights over swidden land in the VFV Law, Farmland Law and draft NLUP. This chapter will explore these three areas of weakness in the current SLM system and propose reforms which will enable the SLM system to cooperate more effectively with existing SLM systems. Each of these areas will be detailed through the lens of changing circumstances in Myanmar. The first issue of identifying swidden land will be discussed in light of mapping customarily held land. The second issue of registering land through collective ownership will be covered in light of rapidly changing social and economic circumstances. The final issue of managing swidden practices will be outlined in light of development on customarily held land.

This thesis focuses on how the recognition of swidden land use rights over customarily held land may be achieved in models of permanent tenure. It will describe how lessons may be learned from other jurisdictions and international research surrounding this area. In particular, it will rely on the Philippines and Cambodia as examples of such models.

The Indigenous Peoples Protection Act 1997 (IPRA) ${ }^{595}$ in the Philippines provides an example of swidden land being included as a form of customary land use. Pursuant to this legislation, indigenous groups follow a process in which their land may be certified, then titled as 'ancestral lands' 596 or 'ancestral domains.' 597 The legislation provides stronger legal ownership, management and use rights over ancestral land. ${ }^{598}$ It upholds the self-determination and maintenance of traditional land use. ${ }^{599}$

In Cambodia, the regulatory framework is constructed from the Land Law 2001, Forest

\footnotetext{
594 Burns and others, above n 22, at 21; Philip Hirsch "Titling against grabbing? Critiques and conundrums around land formalisation in Southeast Asia" in International Conference on Global Land Grabbing (2011) at 8 .

595 Republic Act No 8371 (The Indigenous Peoples’ Rights Act) 1997 (Philippines).

${ }^{596}$ Land that is currently occupied by an indigenous people group. Republic Act No 8371 (The Indigenous Peoples' Rights Act), subs 3(b).

${ }^{597}$ Land, although not currently occupied, over which groups have ancestral claims. Republic Act No 8371 (The Indigenous Peoples’ Rights Act), s 3(a).

598 The provisions require indigenous groups to grant permission for natural resource extraction. Patricia Thompson "Philippines Indigenous Peoples Rights Act” (1999) 10 Colo J Int'l Envtl L \& Pol'y 179.

${ }^{599}$ Republic Act No 8371 (The Indigenous Peoples’ Rights Act), s 51.
} 
Law 2002 as well as various sub-decrees and regulations. ${ }^{600}$ It enables indigenous groups to be recognised by the government, form an incorporated organisation and have land titled as well as traditional practices protected and managed.

$1 \quad$ How swidden land is identified in legislation in light of mapping customarily held land

(a) Issues in Myanmar

There are a number of issues with how the SLM system presently operates in identifying and documenting swidden land in Myanmar. As well as it being unclear to what extent swidden cultivation is affected by the Farmland and VFV Laws, Myanmar's SLM system overlays a rigid and restrictive system of land categorisation which has limited correlation to the CLM systems governing swidden cultivation. ${ }^{601}$ Government statistics on the amount of land affected by swidden are also inaccurate estimates. ${ }^{602}$

The draft NLUP proposals to reclassify and map ancestral land and land use, currently spread across different land categories, are a positive step forward. ${ }^{603}$ However, the wording of the legislation requires greater consistency in order to prevent confusion. ${ }^{604}$ It is unclear when swidden is included or not in various generalised words and phrases. Although some ambiguity may result from the differences between the Burmese original and the English translation of the draft NLUP, there is a lack of consistency in terminology in the original.

(b) In other jurisdictions

In a number of jurisdictions in Southeast Asia, swidden cultivation is either prohibited or tacitly approved. ${ }^{605} \mathrm{In}$ jurisdictions where swidden is permitted, the practice is

600 Kirsten Ewers Andersen, Sek Sophorn and Francesca Thornberry "Development of a Sub-decree on Shifting Cultivation under Article 37 of the Forestry Law (2002), Cambodia" [2007] ILO and Danida 11 at 11.

${ }^{601}$ OECD, above n 146, at 44.

${ }^{602}$ Mertz and others, above n 2, at 284; Schmidt-Vogt and others, above n 1, at 272-273.

${ }^{603}$ Section 72, Roy Prosterman, Laura Eshbach and Darryl Vhugen Commentary on the Draft National Land Use Policy (Full Version) (Landesa, 2014) at [39].

604 TNI Myanmar Programme and TNI Agrarian Justice Programme, above n 31, at 11; Transnational Institute The Challenge of Democratic and Inclusive Land Policymaking in Myanmar: A response to the draft National Land Use Policy (Transnational Institute, 2015) at 59-61.

${ }^{605}$ Y Yasmi, L Kelley and T Enters "Governing the Commons in Asia: Contested Tenure and Conflict over Land and Forests" Sustaining Commons: Sustaining Our Future at 6; For example, Laos and Vietnam. Olivier Ducourtieux, Jean-Richard Laffort and Silinthone Sacklokham "Land policy and farming practices in Laos" (2005) 36 Development and Change 499; Olivier Ducourtieux and Jean-Christophe Castella "Land reforms and impact on land use in the uplands of Vietnam and Laos: Environmental protection or poverty alleviation" in Colloque international "Les frontières de la question foncière-At the frontier of land issues", Montpellier (2006); and Indonesia. Tanya Murray Li "Masyarakat Adat, Difference, and the Limits of Recognition in Indonesia's Forest Zone" (2001) 35 Modern Asian Studies 645 at 670. 
incorporated into legislation regulating customary or indigenous land management. ${ }^{606}$

Given the difficulties in defining swidden cultivation, it is not specifically defined in these documents, rather it is included as a type of land use undertaken on customarily held land. ${ }^{607}$ In the Philippines indigenous groups rely on the IPRA. Once recognised by the government, they are able to self-identify the land use they undertake on particular land. ${ }^{608}$ Swidden cultivation is specifically used as an example of 'subsistence and traditional activities' which indigenous groups may undertake on ancestral land. ${ }^{609}$ In Cambodia, there are specific provisions recognising swidden cultivation. This includes land both under cultivation as well as swidden fallows. ${ }^{610} 611$

\section{(c) Application in Myanmar}

It is not clear whether the draft NLUP will extend as far as the Philippines or Cambodia in recognising shifting cultivation. Subsection 70(b) of the draft NLUP states:

70. In carrying out preparation work of traditional land use maps and records of the ethnic nationalities, the relevant responsible persons:

$[\ldots]$

(b) shall recognize and protect the traditional rights, land use and land tenure right of the ethnic nationalities who are using land whether or not the existing land use is mentioned in records and maps, and registered;

This subsection suggests that potentially all existing customary land rights and land use practices will be identified, mapped and protected in this process. This would include all swidden land and appears to protect swidden cultivation as a type of 'traditional...land use'. This aligns with s 68 which appears to recognise traditional land use rights and practices and subs $34(\mathrm{~d})$ as protecting 'rotating taungyas'. However, other sections of the

\footnotetext{
606 Cairns, above n 72, at 71-73; For example, in Mexico: Fikret Berkes, Carl Folke and Johan Colding Linking Social and Ecological Systems (Cambridge University Press, 2000); the Philippines: Wolfram Dressler "Green governmentality and swidden decline on Palawan Island" (2014) 39 Transactions of the Institute of British Geographers 250 at 253-254; and Cambodia RECOFTC - The Center for People and Forests Community forestry adaptation roadmap to 2020 for Cambodia (2014) at 27.

${ }^{607}$ In Cambodia: Royal Decree NS/RKM/0801/14 (Land Law) 2001 (Cambodia), p article 25; Sub decree on procedures of registration of land of indigenous communities 2009 (Cambodia), p article 6; Republic Act No 8371 (The Indigenous Peoples’ Rights Act) 1997 (Philippines), subs 3(a) and s 51.

${ }^{608}$ Republic Act No 8371 (The Indigenous Peoples' Rights Act), s 51.

${ }^{609}$ Republic Act No 8371 (The Indigenous Peoples' Rights Act), subs 3(a); Baver and others, above n 136, at 99.

${ }^{610}$ Royal Decree NS/RKM/0801/14 (Land Law), p article 25; Sub decree on procedures of registration of land of indigenous communities, art 6.

${ }^{611}$ Royal Decree NS/RKM/0802/016 (Forestry Law) 2002 (Cambodia), art 37.
} 
draft NLUP are less clear. ${ }^{612}$

Section 72 states that ancestral land will be reclassified according to the new national land law. However, the lists land categories ${ }^{613}$ and land zones ${ }^{614}$ do not include a specific classification named 'ancestral land'. Swidden cultivation could fit into several of these categories at different stages of the swidden cycle.

Section 74 also provides for determining which land is forest or agricultural land and which '[applies] alternative farming method[s]'. The apparent intention of this provision is for land classifications to better reflect actual land use. Rural land could be classified as either forest or agricultural land depending on how it is actually used. However, is unclear how swidden land fits into this process. 'Alternative farming method' could refer to swidden cultivation. However, this is not entirely clear. ${ }^{615}$ Assuming that the section does include swidden cultivation, it then raises the question of whether the Myanmar government intends for swidden cultivation to be classified as forest land, agricultural land or a separate land category. Swidden land does not comfortably fit as being agricultural land or forest land. However, if it is classified as a separate category, this has not been mentioned in the list of land classifications ${ }^{616}$ or land use zones. ${ }^{617}$

(d) Proposed reforms

If swidden cultivation is brought under the scope of the Farmland law or VFV law, it would require clarification as to whether swidden cultivation is included. This could be addressed by specifically referring to swidden cultivation into both pieces of legislation. For example, the definition of Farmland in s 3 of the Farmland Law could be amended to specifically include swidden cultivation. It would also require a clarification of a number of the provisions of the law, such as subs 12(i) ${ }^{618}$ which prohibits land being left fallow without good cause and $\mathrm{r} 116^{619}$ which encourages the sedentarisation of swidden cultivators.

612 TNI Myanmar Programme and TNI Agrarian Justice Programme, above n 31, at 18; Transnational Institute, above n 604, at 9.

${ }^{613}$ Government of the Republic of the Union of Myanmar Land Use Allocation and Scrutinizing Committee, above $\mathrm{n} 30$, at s 19 .

614 At s 31.

615 The Burmese original uses the word 'taungya' (60ssćs ) in this phrase.

${ }^{616}$ Government of the Republic of the Union of Myanmar Land Use Allocation and Scrutinizing Committee, above n 30, at s 19.

${ }^{617}$ At s 31; Government consultants at the consultation meeting at the release of the draft NLUP suggested mixed use categories. "Land Use Allocation and Scrutinizing Committee Consultation Meeting on Draft National Land Use Policy Minutes" (18 October $<$ http://www.burmalibrary.org/docs19/Draft_National_Land_Use_Policy_Pre-Consulation_18_OctMinutes-en.pdf>.

618 Farmland Law 2012 (Myanmar).

${ }^{619}$ Farmland Rules 2012 (Myanmar). 
If it is brought into a National Land Law based on the draft NLUP, the meaning and intent of the provisions dealing with ethnic nationality land use rights would need to be clarified. ${ }^{620}$ In order to reform this aspect of the SLM, it would be useful to streamline the various phrases used when referring generally to customarily held land, ${ }^{621}$ customary land use ${ }^{622}$ and swidden cultivation. ${ }^{623}$ It would avoid obscurity and confusion if a single term was used for each of these three concepts.

Myanmar could follow the Philippines and Cambodia by establishing a separate land category which encompasses customarily held land and extends over different categories of land use. Establishing a separate land category for customarily held land would allow it to be managed more easily according to traditional practices. This would give greater local flexibility in determining how land is used. ${ }^{624}$

It could then follow the Philippines through recognising traditional and customary land uses generally. The recognition of land in this way would enable the recognition of CLM systems controlling this land and traditional land use practices, such as swidden cultivation. Alternatively, it could follow Cambodia through enacting more specific provisions which deal with swidden land. It would be helpful to recognise swidden land that is both under cultivation and that which is rotational fallow.

\section{Mapping of swidden land}

In the draft NLUP, the Myanmar government has recognised its need for greater understanding of current land use, including customary land use. ${ }^{625}$ Maps of many outlying areas were produced in colonial times and are now highly inaccurate. ${ }^{626}$

Problems in practically documenting swidden land have also been faced in other Southeast Asian countries. ${ }^{627}$ For example, Peluso discusses Indonesia's attempt to map

\footnotetext{
620 TNI Myanmar Programme and TNI Agrarian Justice Programme, above n 31, at 11.

${ }^{621}$ Called "ancestral land" Government of the Republic of the Union of Myanmar Land Use Allocation and Scrutinizing Committee, above n 30, at ss 71 and 72; and "land tenure rights of the ethnic nationalities" At Part VII, ss 70(b), 73, 75, 77 and 80(d)(iv).

${ }^{622}$ Called "traditional land use practices" Government of the Republic of the Union of Myanmar Land Use Allocation and Scrutinizing Committee, above n 30, at s 68, 70(a) and (b); "lands cultivated by traditional methods" At ss 34(d), 61(b) and 71; and "customary land use or non-registered land use claims" At s 82(j).

623 referred to as "taungya farming" Government of the Republic of the Union of Myanmar Land Use Allocation and Scrutinizing Committee, above n 30, at s 57; "alternative farming method" At ss 57 and 74 ; "rotating taungyas" At subs 33(d); and "traditional alternative taungya system." At s 75.

${ }^{624}$ Sturgeon, above n 189, at 168.

${ }^{625}$ Government of the Republic of the Union of Myanmar Land Use Allocation and Scrutinizing Committee, above $\mathrm{n} 30$, at s 82 .

626 Baver and others, above n 136, at 87; Hunt, above n 555.

${ }^{627}$ Roth, above n 193.
} 
forests in their outer islands. ${ }^{628}$ She notes the State's underestimation and lack of knowledge of localised customary land claims, boundaries and land use. ${ }^{629}$

A way to overcome this issue is to bridge the gap between State and local knowledge of swidden land. As CLM systems are locally specific, the most appropriate starting point for this is to communicate with local communities. It is local communities which are able to identify land that is held customarily. ${ }^{630}$

In the Philippines, the identification of ancestral land is guided primarily by the principle of self-delineation. ${ }^{631}$ The government established a separate governmental organisation, The National Commission on Indigenous Peoples (NCIP), to provide formal oversight to support indigenous people groups in the identification and mapping of their ancestral domains. ${ }^{632}$ The IPRA establishes detailed guidelines about how ancestral domains are established and reinforces that processes must be followed according to traditional customs. ${ }^{633}$

In Cambodia, although still self-delineating, the process is more structured around state land administration organisations. If a village is unable to agree with its neighbours on boundaries to its collective land, then there is a defined procedure to follow in order to clarify land boundaries. In these circumstances, the local land administration body is responsible for delineating the land boundaries in consultation with the local community. 634 The Cambodian government has produced a standardised participatory land-use planning (PLUP) process. ${ }^{635}$ This has helped give greater direction to NGOs who assist community groups with mapping projects.

\footnotetext{
628 Nancy Lee Peluso "Whose Woods Are These? Counter-Mapping Forest Territories in Kalimantan, Indonesia" (1995) 27 Antipode 383 at 389-392.

${ }^{629}$ At $390-391$.

${ }^{630}$ Deininger and others, above n 39, at 31.

631 Republic Act No 8371 (The Indigenous Peoples’ Rights Act) 1997 (Philippines), s 51.

${ }^{632}$ Randy Abeto and others "Community Mapping in the Philippines: A Case Study on the Ancestral Domain Claim of the Higa-onons in Impasug-ong, Bukidnon" (paper presented to Regional Community Mapping Network Workshop, Quezon City, Philippines) at 4; Although the NCIP has been under-funded. Office of the United Nations High Commissioner for Human Rights Philippines Indigenous Peoples ICERD Shadow Report (2009) at 22.

${ }^{633}$ Republic Act No 8371 (The Indigenous Peoples’ Rights Act), ss 52-53.

${ }^{634}$ Sub decree on procedures of registration of land of indigenous communities 2009 (Cambodia), p article 10.

635 Klot Sarem, Jeremy Ironside and Georgia Van Rooijen "Understanding and Using Community Maps Among Indigenous Communities in Ratanakiri Province, Cambodia” in Jefferson Fox, Krisnawati Suryanata and Peter Hershock (eds) Mapping Communities: Ethics, Values, Practice (East-West Center, Honolulu, Hawai'i, 2005) 43 at 45.
} 
(a) GIS mapping technologies

Although the nature of swidden makes mapping it difficult, technologies such as Geographic Information Systems (GIS) have made it easier and more accessible. ${ }^{636}$ Engaging local communities in mapping has been presented as a means of "empowerment, expanded participation, social capacity and inclusion, equity and redistribution, and increased democracy" ${ }^{637}$ In practical terms, it has often been used in order to protect local communities against land-grabbing by the State or commercial interests. ${ }^{638}$ In light of the access model, it can be viewed as a means of enabling the SLM system and CLM systems to cooperate, rather than conflict. Identifying and mapping swidden land would help produce information which was previously unavailable to the SLM and could enable existing land use to be more accurately understood and recognised. It also increases the power of local communities in managing access to natural resources, ${ }^{639}$ which in turn strengthens CLM mechanisms of access.

(b) Application to Myanmar

While the draft NLUP contains various provisions detailing how the land use information and maps will be amended and produced, it is less clear how this will be undertaken in areas primarily managed by CLM systems.

The draft NLUP includes various provisions relating to the identification and mapping of current land use. ${ }^{640}$ It proposes the formation of a National Land Use Council, ${ }^{641}$ which is empowered to form District Land Use Committees. ${ }^{642}$ These governmental bodies are tasked with understanding current land use, harmonizing existing land records and generating more accurate land use maps. ${ }^{643}$ However, the document also mentions

\footnotetext{
${ }^{636}$ Peluso, above n 628, at 400; See Sieber for a comprehensive review of the various types of Public Participation Geographic Information Systems. Renee Sieber "Public Participation Geographic Information Systems: A Literature Review and Framework" (2006) 96 Annals of the Association of American Geographers 491; And Threlkeld et al. for an overview of GIS mapping indigenous land Bill Threlkeld, Mac Chapin and Zachary Lamb "Mapping indigenous lands" (2005) 34 Annu Rev Anthropol 619.

${ }^{637}$ J Peter Brosius, Anna Lowenhaupt Tsing and Charles Zerner "Representing communities: Histories and politics of community-based natural resource management" (1998) 11 Society \& Natural Resources 157 at 161-162; Sieber, above n 636, at 501.

638 Jefferson Fox "Siam Mapped and Mapping in Cambodia: Boundaries, Sovereignty,and Indigenous Conceptions of Space" (2002) 15 Society \& Natural Resources 65 at 73.

${ }^{639}$ Brosius, Tsing and Zerner, above $\mathrm{n}$ 637, at 162.

${ }^{640}$ Government of the Republic of the Union of Myanmar Land Use Allocation and Scrutinizing Committee, above n 30, at Part II chapters I and II, Part VII.

${ }^{641}$ At s 15.

${ }^{642}$ At s 17.

${ }^{643}$ At s 18.
} 
District Management Bodies ${ }^{644}$ and Township Administration Bodies. ${ }^{645}$ These administrative bodies are tasked with determining land use zones and changes in types of land use. ${ }^{646}$ They are also tasked with understanding and mapping traditional land use rights in 'ethnic nationality' areas. ${ }^{647}$

It appears that localised knowledge of customary land rights remains strong. Customary land rights are informal and unwritten, yet well-understood by local farmers. 648 This means that local communities would have the greatest and most precise understanding of customary land use rights and the use of swidden cultivation within a specific location.

The Draft NLUP seems to take a consultative approach to obtaining local land use knowledge, although it is driven by local land management bodies. ${ }^{649}$ Subsections 23(f), 26(e) and 82(1) specifically mention using participatory mapping processes in order to produce land use maps. Regarding ethnic nationality areas, s 70 states that maps will be prepared in consultation with local leaders who have expertise in these matters. However, questions remain as to how these leaders will be found and asked to participate. ${ }^{650}$

It has been suggested that the mapping process be more 'bottom-up. ${ }^{651} \mathrm{~A}$ local NGO's submission in response to the draft NLUP submitted that mapping should originate at a community level with local farmers, rather than district level land administrators. They highlighted that it would be more efficient and produce more accurate maps for maps to be twice checked by bureaucratic administration once has been generated by community, rather than vice versa. ${ }^{652}$

\footnotetext{
${ }^{644}$ At s 29.

${ }^{645}$ At s 32; It is not clear what is referred to with regard to these bureaucratic bodies. However, they most likely refer to the existing local administrative bodies which were first established by the Land Nationalisation Act 1953 and have taken various forms since then. At s 11; At the consultation meeting at the release of the draft NLUP, it was suggested that these administrative bodies would eventually be merged into one. "Land Use Allocation and Scrutinizing Committee Consultation Meeting on Draft National Land Use Policy Minutes", above n 617.

${ }^{646}$ Government of the Republic of the Union of Myanmar Land Use Allocation and Scrutinizing Committee, above n 30, s 29-32.

${ }^{647}$ At 69.

${ }^{648}$ Baver and others, above n 136, at 57; Food Security Working Group, above n 411, at 4.

${ }^{649}$ Government of the Republic of the Union of Myanmar Land Use Allocation and Scrutinizing Committee, above $n$ 30, at ss 23-32 and 69-70.

${ }^{650}$ The English translation suggests assistance may be involuntary. Transnational Institute, above n 604, at 60.

651 At 50 .

652 Memorandum from Rachael Knight and Laura Goodwin (Namati) to the Government of Myanmar (Land Use Allocation Scrutinizing Committee) regarding Comments on Myanmar National Land Use Policy (Draft) (30 December 2014).
} 
An added complication to mapping land in Myanmar is the scale of internal displacement within Myanmar as well as the large number of refugees living in surrounding countries. Groups with ancestral connections to various areas may have fled or been relocated elsewhere. This land may be left deserted or occupied by others ${ }^{653}$ and is particularly vulnerable to being allocated as agricultural or forestry concessions. There have been calls to prohibit concession grants on this type of land. ${ }^{654}$ It is important that there is clarity as to who is able to claim land use rights over areas of land affected by conflict and internal displacement. 655

\section{(c) Proposed reforms}

The draft NLUP proposes pilot programmes involving participatory mapping ${ }^{656}$ and the recognition of customary land use and land rights. It would be useful to conduct pilot programmes for mapping customarily held land in order to generate locally relevant and applicable processes and guidelines for GIS mapping. ${ }^{657}$ It has been suggested that participatory mapping is most successful in situations where there is a supportive regulatory environment and high community ownership. ${ }^{658}$ Therefore any central government legislation or policy that supports effective participatory mapping processes would enable greater success. The research generated from these pilot projects could also enable mitigation of some of the negative effects of mapping customarily held land outlined below.

Local NGOs in Myanmar have so far been involved in mapping swidden land in conjunction with collective land registration research. ${ }^{659}$ They have concluded that it is useful to engage in the preliminary mapping of communities in order to assist communication with government authorities with formal registration processes. ${ }^{60}$

\footnotetext{
${ }^{653}$ Smith, above n 7, at 119 and 476; Butwell, above n 422, at 98.

654 "Civic organisations urge govt, ethnic armed groups not to sell land in conflict zones" Eleven (Myanmar, 9 February 2015)

<http://www.elevenmyanmar.com/index.php?option=com_content\&view=article\&id=8979:civicorganisations-urge-govt-ethnic-armed-groups-not-to-sell-land-in-conflictzones\&catid=44: national \&Itemid=384>.

655 Transnational Institute, above n 604, at 8, 9 and 20.

${ }^{656}$ Government of the Republic of the Union of Myanmar Land Use Allocation and Scrutinizing Committee, above $n$ 30, at 82(1).

${ }^{657}$ Based on international experience in indigenous land mapping. Threlkeld, Chapin and Lamb, above n 636.

${ }^{658}$ Stefano Di Gessa, P Poole and T Bending "Participatory mapping as a tool for empowerment: Experiences and lessons learned from the ILC network" [2008] Rome: ILC/IFAD at 3.

659 Kirsten Ewers Anderson "LCG Case studies in Chin and Shan states on codification of customary agricultural communal tenure" (Myanmar National Dialogue on Community Tenure, Myanmar, 13 January 2015); Hunt, above n 555.

${ }^{660}$ Kirsten Ewers Anderson, above n 659.
} 
In situations where there has been considerable internal displacement or movement of refugees, the concept of ancestral domain in the IPRA could be applied. The definition of 'ancestral domains' in the IPRA includes areas that "may no longer be exclusively occupied...but from which they traditionally had access to for their subsistence and traditional activities." 661 War, forced displacement and other dealings which may have alienated land from these groups are noted as exceptions to the requirement of continuous use in order to claim ancestral domain. In this situation, existing land users may continue to use land. However, compensation or some form of land rental could be provided for the use of the land and further development would require the ancestral group's permission. This would mean that groups that held historical connections to land, but had left due to civil conflict would be able to claim some form of compensation from the state or current land users.

(d) Adverse effects of mapping swidden land

Although mapping swidden land can have positive effects on the formal recognition of customary land use rights, there can also be negative consequences. ${ }^{662}$ Fox details four major issues that can arise where there are localised mapping projects. International research surrounding the identification and documentation of swidden land raises various issues which may arise during the implementation of this policy.

(e) Loss of local concepts of space

Firstly, it replaces local concepts of space with lines on a map which are difficult to change. 663 Johnson warns that mapping from a purely Western cartographic framework erases indigenous concepts. ${ }^{664}$ In order to minimise this problem, local leaders receive more than a simple base knowledge of GIS. Rather, a deeper understanding of what can be achieved through GIS may enable better and richer quality information being stored. Land holding and use information is not simply limited to cartographic maps, but may also include songs, rituals and songs. ${ }^{665}$ These elements may all be stored in GIS database systems. ${ }^{666}$ On the other hand, Rundstrom concludes that GIS information gathering is inherently destructive

\footnotetext{
${ }^{661}$ Republic Act No 8371 (The Indigenous Peoples’ Rights Act) 1997 (Philippines), p subs 3(a).

662 Brosius, Tsing and Zerner, above n 637; Fox, above n 638; Threlkeld, Chapin and Lamb, above n 636; Jake Kosek "Mapping politics" (1998) 45 The Common Property Resource Digest 4.

${ }^{663}$ Fox, above n 638, at 66.

${ }^{664}$ Jay T Johnson, Renee Pualani Louis and Albertus Hadi Pramono "Facing the future: Encouraging critical cartographic literacies in indigenous communities" (2006) 4 ACME: an international e-journal for critical geographies 80 at 87-88.

665 At 91.

${ }^{666}$ At 94.
} 
to indigenous knowledge and practices. ${ }^{667}$

While, ideally, villagers would be able to gain proficient training in GIS technologies in order to comprehensively map their ancestral lands, achieving this is problematic. In Cambodia, NGOs experienced numerous difficulties in implementing participatory mapping projects. Within remote areas, there were low levels of literacy and education. Villagers had difficulty interpreting topographic maps and GIS equipment was even more difficult to read as instructions are not in their native language. Trainings in this technology occurred too infrequently and so skills and knowledge were often lost during the intervening periods. ${ }^{668}$ Attempts at using local people to train and regularly visit villages in relation to mapping issues was prevented by the Cambodian government. 669

NGOs also found that there was a trade-off between the speed at which maps were produced and the understanding of the villagers. In situations where urgent action was taken to address imminent land grabs, maps that were produced were not well understood by communities. The standardised process for communal land mapping introduced by the Cambodian government meant that mapping was more detailed and took a greater amount of time. ${ }^{670}$

In the Philippines, subs 52(d) of the IPRA contains a list of various types of evidence that may be used in relation to a claim for ancestral domain. They range from written accounts of traditions and customs and accounts of agreements made with neighbouring groups about boundaries to "pictures and descriptive histories of traditional communal forests and hunting grounds." The greater range of material that is admissible in order to prove customary land tenure, the more likely that localised concepts of tenure will be retained rather than lost.

The draft NLUP does not specify the type of information regarding ancestral land boundaries, management and use which would be acquired. Correspondence with UNHabitat about the registration process under the Farmland Law suggests a generic process. Allowing a more nuanced and locally-specific information gathering and recording would help mitigate losses in indigenous concepts and knowledge as swidden land is registered. Furthermore, it would be helpful for local leaders with expertise in customary land rights to also receive more in depth training in GIS systems so that the conversion of knowledge from CLM systems to the SLM system results in as little loss of information as possible.

\footnotetext{
${ }^{667}$ Robert A Rundstrom "GIS, indigenous peoples, and epistemological diversity" (1995) 22 Cartography and geographic information systems 45 at 45 .

${ }^{668}$ Sarem, Ironside and Van Rooijen, above n 635, at 46.

${ }^{669}$ At 53 .

${ }^{670}$ At 45 .
} 
Section 22 mentions 'complete, precise and correct' information twice times in its description of expectations of information management systems. A 'complete' account of CLM systems would include more than types of land use within boundary lines. There could be opportunity to include a greater depth of land management information in the GIS database. There would need to be sufficient time and resource allocated to the implementation of mapping projects.

As land use rights to unregistered land is currently proved to state administrative bodies through tax receipts and sketch maps taken by SLRD officers, it would be necessary to broaden the scope of acceptable evidence for proof of land use rights. ${ }^{671}$ It would be useful to include a list similar to that in the IPRA.

(f) Increased conflict

The identification and clarification of land boundaries is a key component advocated by those seeking greater security of tenure. ${ }^{672}$ While it has been articulated that improved tenure security decreases conflict, ${ }^{673}$ boundary clarifications as part of this process can instead increase inter-village conflict as previously fluid and overlapping rights are fixed more solidly. ${ }^{674}$ In the Philippines, conflict between neighbouring indigenous groups over boundaries have stalled ancestral certification and titling processes. ${ }^{675}$

While conflict over the identification and documentation of swidden land use rights may not be prevented altogether, they may be mitigated. If land use rights identified and documented under the SLM resemble as closely as possible those offered in the CLM system, the potential for conflict can be decreased. ${ }^{676}$

There are tools available to enable more effective facilitation of boundary delineation. Rambaldi describes the use of Participatory 3 Dimensional Maps (P3DM) in both delineating traditional land boundaries and resolving conflict between neighbouring

\footnotetext{
${ }^{671}$ Baver and others, above n 136, at 88; Memorandum from Rachael Knight and Laura Goodwin (Namati) above at $\mathrm{n} 670$.

${ }^{672}$ Klaus W Deininger Land Policies for Growth and Poverty Reduction (World Bank Publications, 2003) at xxiii; Sumarto and Hadjono 2002, iii; Lunnay 2010, 5 cited in Hirsch, above n 594, at 8; Hernando de Soto Mystery of Capital: Why Capitalism Triumphs in the West and Fails Everywhere Else (Basic Books, 2003).

${ }^{673}$ Di Gessa, Poole and Bending, above n 658, at 12; Deininger, above n 587, at 5; Section 18(c) of the draft NLUP directly links reduction in conflict to the clarification of land boundaries. Government of the Republic of the Union of Myanmar Land Use Allocation and Scrutinizing Committee, above $\mathrm{n} 30$.

${ }^{674}$ Fox, above n 638, at 73; Hall, Hirsch and Li, above n 52, at 49; Peluso, above n 628, at 388; Roth, above n 193, at 210.

${ }^{675}$ Ruth Sidchogan-Batani Expert Seminar on Treaties, Agreements and other Constructive Arrangements Between States and Indigenous Peoples Geneva 15-17 December 2003 HR/GENEVA/TSIP/SEM/ 2003/BP.4 (2003) at $6-7$.

${ }^{676}$ Deininger, above n 587, at 7.
} 
villages. ${ }^{677}$ However, he highlighted the need for an understanding of what may bring about consensus between groups, involving trusted third parties and establishing "sufficient trust, effective communication and transparency." 678

The draft NLUP uses the word 'precise' 7 times in relation to maps. ${ }^{679}$ This reveals the Myanmar government's clear intention to establish well-defined land boundaries. The process is presented as leading to reduced land disputes. ${ }^{680}$ However, as outlined above, it could result in increased land conflict as latent disputes surface.

Again, in Myanmar pilot programmes could establish best-practice procedures with regard to mitigating and resolving conflicts that arise during mapping projects. It would be important to ensure local communities received sufficient power and that the process occurred without corrupt influence or coercion. ${ }^{681}$ If power imbalances are not rectified in conflict situations, it may entrench the weakness of villages holding customary land. ${ }^{682}$

(g) Alternative agendas

Thirdly, entities assisting localised communities in mapping projects may also have differing interests and agendas to those of the community. ${ }^{63}$ As shown through Myanmar's history, the state has had different reasons for mapping land. These reasons range from the Colonial British desire to extend influence, exploit resources and generate tax revenue to the most recent reforms which encourage local land markets and foreign investment.

Some writers have linked mapping projects with state territorialisation. ${ }^{684}$ Vandergeest and Peluso put forward how states' agendas to affect, influence or control the public also alter over time. From an initial desire to claim territory, secure resources and raise tax revenue, they then outline the move to surveillance, information gathering and the sedentarisation

677 Giacomo Rambaldi and others "Bringing the vertical dimension to the negotiating table" (2002) 2 Preliminary assessment of a conflict resolution case in the Philippines ASEAN Biodiversity 17; Giacomo Rambaldi and CJ Tarr "Participatory 3-D Modelling: Bridging the GAP between Communities and GIS Technology" in international workshop" Participatory Technology Development and Local knowledge for sustainable Land use in Southeast Asia" Chiang Mai, Thailand (2001); Giacomo Rambaldi Participatory Three-dimensional Modelling: Guiding Principles and Applications (2010 edition ed, ACP-EU Technical Centre for Agricultural and Rural Cooperation (CTA, Wageningen, the Netherlands, 2010).

${ }^{678}$ Rambaldi, above n 677, at 17; Rambaldi and others, above n 677, at 25.

${ }^{679}$ Government of the Republic of the Union of Myanmar Land Use Allocation and Scrutinizing Committee, above $n$ 30, ubs 18(b) and (c), 22(a), (b) and (c), 80(d)(v) and 82(i).

${ }^{680}$ At subs 18(c).

${ }^{681}$ Baver notes the power government officials have in relation to village leaders. Baver and others, above $n$ 136 , at $61,64,77$ and $81-82$.

${ }^{682}$ Daniel Adler and Jeremy Ironside "Mapping Indigenous Communal Lands: A Review of the Literature from a Cambodian Perspective" [2009] at 2.

${ }^{683}$ Fox, above n 638, at 66.

${ }^{684}$ Vandergeest and Peluso, above n 65, at 390; Fox, above n 638, at 73-74; Robert David Sack Human Territoriality (CUP Archive, 1986) at 19. 
of cultivators. ${ }^{685}$

In Myanmar, commentators have described the movement of powerful military elite into the economic sphere. As Myanmar's military releases more of its political power to democratic processes, its most powerful players have secured greater control within the economic sphere. ${ }^{686}$ Likewise, in conflict areas, writers have described the use of investment projects to extend government control into cease-fire areas. ${ }^{687}$

There has also been a strong conservationist movement throughout Southeast Asia in the past 2 decades. Kosek warns that organisations involved in mapping may incorrectly assume that indigenous groups align with conservationist agendas. ${ }^{688}$ Maps may be produced on the premise of forest conservation, whereas villagers may desire more agricultural development. ${ }^{689}$

The policies proposed to address conflict and the introduction of free, prior and informed consent (FPIC) ${ }^{690}$ could also be effective in mitigating the effects of alternative agendas.

(h) Control of access to mapping and land-use information

Lastly, control of access to mapping and land-use information is not often established. ${ }^{691}$ This aspect links with the previous in that those involved with mapping may use this information for other purposes. Rambaldi noted that maps sometimes contained sensitive information, such as the location of endangered species and valuable natural resources. He recommended mapping these areas behind closed doors, controlling who has access to the information and removing the information from any maps that are publicly displayed. ${ }^{692}$

Not only does the control of maps help protect valuable resources, if it also enables communities to interpret the information on the maps. This can occur through story-telling and can help preserve local knowledge. 693

The draft NLUP mentions the need for accessible land use information. ${ }^{694}$ However, how this will practically occur is not elaborated. Hard-copy maps may be more accessible

\footnotetext{
685 Peluso, above n 628, at 390.

686 Jones, above n 10.

${ }^{687}$ Woods terms this process “cease-fire capitalism” Woods, above n 331; Woods, above $n 3$.

${ }^{688}$ Kosek, above n 662, at 5.

${ }^{689}$ Hall, Hirsch and Li, above n 52, at 45; Walker, above n 4; Li, above n 20.

${ }^{690}$ See discussion regarding FPIC below.

${ }^{691}$ Fox, above n 638, at 66.

692 Rambaldi, above n 677, at 17.

693 At 75-76.

${ }^{694}$ Government of the Republic of the Union of Myanmar Land Use Allocation and Scrutinizing Committee, above n 30, ubs 9(c), 22(c), 23(c) and s 64.
} 
to local communities without internet access. However, the information on these resources can quickly become out of date and maps must be remade rather than updated. Electronic databases also have positive and negative aspects. Minor adjustments can be done relatively easily and maps could be kept more up to date. However, there is significant cost associated with establishing and maintaining GIS databases. ${ }^{695}$ This makes them prohibitively expensive for indigenous organisations, especially in developing countries. Lack of internet access in rural villages makes it difficult to access GIS information. ${ }^{696} \mathrm{~A}$ local NGO responding to the draft NLUP raised concerns that the cost of producing maps could potentially lead to maps not being made. ${ }^{697}$

Peluso extends that empowerment should not only mean enabling communities to produce maps, rather, it should also mean the empowerment to change and renegotiate maps. ${ }^{698}$ Maintaining localised control of mapping information would enable this to occur more naturally.

In order for villages to retain greater control of mapping it would be necessary to conduct adequate training and education to accompany the production of maps. As governmental and NGO resources would be limited, it could be useful to train local villagers who are able to keep their local communities sufficiently skilled in mapping technologies and understand the necessary processes to adjust maps.

3 Management of swidden land (recognition of communal ownership in a period of economic transition.)

Myanmar's current SLM system does not clearly recognise collective land holding. It is also experiencing significant economic pressures which encourage the formation of more individualised, rather than collective land holding. This section will firstly detail the arguments surrounding whether to keep communal land tenure or move towards individualised titling systems. It will then propose collective management structures that are sufficient flexible to allow the transition from collective to individualised title in the face of rapid transition in market engagement. 699

(a) Evolution of Land Rights

Formalisation of land title has been viewed as part of a natural progression towards private, individual land titles. Demsetz developed the theory that property rights evolve from

\footnotetext{
695 Threlkeld, Chapin and Lamb, above n 636, at 629.

696 At 630.

${ }^{697}$ Prosterman, Eshbach and Vhugen, above n 603, at [11].

698 Peluso, above n 628, at 400-401.

${ }^{699}$ Deininger and others, above n 39, at 29.
} 
informal, communal and customary and to formal, individual and state-defined. ${ }^{700}$ The theory places land rights on a progressing continuum. ${ }^{701}$

As land resources become scarcer, existing land is used more intensively. Then, because more intensive land use requires greater investment in plots of land, communities develop institutions which enable individuals to benefit from their investment. The processes developed by a community in response to the rising value of land move the form of land tenure along the continuum from informal rights to more formal land rights. ${ }^{702}$ Proponents of this theory have implied that the movement towards private, individual title is more desirable. ${ }^{703}$ However, even amongst advocates, this theory has been criticised as over-simplistic. ${ }^{704}$

Those in favour of conversion to individual titles argue that they make land owners more likely to invest in their land to make it more productive, ${ }^{705}$ have more incentive to invest in their land ${ }^{706}$ and have greater access to credit in order to invest in the land. ${ }^{707} 708$

Furthermore, they also highlight negative aspects associated with systems of communal land tenure. Hardin's famous "tragedy of the commons" has been particularly influential in this respect. ${ }^{709}$ Accounts describe communal tenure as wasteful and inefficient as they encourage over-exploitation of resources, ${ }^{710}$ exploitation of resources as quickly as possible ${ }^{711}$ and investment in areas which may produce lower returns, but are easier to protect. ${ }^{712}$ Fitzpatrick also cautions that communal ownership does not always result in fair distribution of wealth and resources. This particularly occurs if there is intragroup conflict or a group leader takes advantage of their position and exercises opportunistic behaviour. ${ }^{713}$

\footnotetext{
700 Demsetz, above n 14.

${ }^{701}$ Fitzpatrick, above n 587, at 449; Demsetz, above n 14, at 350; de Soto, above n 672.

702 Deininger, above n 672, at 9-10.

703 Trebilcock and Veel, above n 589, at 400.

${ }^{704}$ At 400; Fitzpatrick, above n 587, at 453; Deininger, above n 672, at xlv.

705 As they need to use their limited land more intensively.

706 As they will directly receive the benefits of this.

${ }^{707}$ As titled properties are able to be used as collateral more easily than untitled properties Trebilcock and Veel, above n 589, at 408.

708 de Soto, above n 672, at 6.

${ }^{709}$ Garrett Hardin "The tragedy of the commons" (1968) 162 science 1243.

${ }^{710}$ As individuals do not consider the effect of their actions upon others within the group.

${ }^{711}$ So others do not obtain these resources first.

712 So the individual is able to reap some direct benefit for their labour. Trebilcock and Veel, above n 589, at 404-5.

${ }^{713}$ Fitzpatrick, above n 587, at 454.
} 
(b) Which type of land tenure more appropriate

There is widespread agreement that land rights develop in a myriad of different ways depending on existing legal systems as well as geographical, social and political conditions. 714 Systems recognising land rights in different jurisdictions will respond to external phenomena differently.

There is significant support that individualisation of land titles does not work in all circumstances. ${ }^{715}$ Brenda-Beckman and Peluso state that individualisation of land titles does not always result in more secure land rights or poverty alleviation. Rather, it can cause unequal distribution, increased conflict and alienation from land ownership. ${ }^{716}$ It appears from the surrounding literature, that the benefits of individual ownership are contingent on other geographic, economic and social factors. Deininger states that for groups with "low population density, high environmental risk, and limited access to infrastructure and markets" 717 it may not be economically worthwhile converting tenure from collective to individualised ownership.

The 'cost' of individualisation is not only the financial cost associated with actually producing the land title, which in itself is significant. ${ }^{718}$ There is also the cost of losing communal benefits. In areas where there is high environmental risk or where the return for produce is low, communal tenure can provide individuals with a form of insurance. ${ }^{719}$ Individualising land titles exposes villagers to stronger economic forces that may be detrimental in the long term, by causing problems of landlessness and entrenching poverty. 720

In areas where land is customarily managed and collectively held, individual titling would inherently weaken the CLM system governing the land. It would not be possible to convey the information from a CLM system into the SLM system through a process of

\footnotetext{
${ }^{714}$ Chuthatip Maneepong and Chung-Tong Wu "Comparative borderland developments in Thailand" (2004) 21 ASEAN Economic Bulletin 135 at 39; Trebilcock and Veel, above n 589, at 477; Burns, above n 348, at 6; Deininger, above n 672, at 4 and 7.

715 Deininger, above n 672, at xxvii; Deininger and others, above n 39, at 28.

716 Toon van Meijl and Franz von Benda-Beckmann Property Rights and Economic Development (Routledge, 1999); Nancy Lee Peluso, Alice B Kelly and Kevin Woods "Context in Land Matters: Access Effects and History in Land Formalization" (paper presented to Commoners and the Changing Commons: Livelihoods, Environmental Security, and Shared Knowledge, the Fourteenth Biennial Conference of the International Association for the Study of the Commons, Mt Fuji, Japan, 2013) at 4-5; Baver and others, above n 136, at 47-48.

${ }^{717}$ Deininger, above n 672, at 30.

718 Godden and Tehan, above n 187, at 154.

719 Deininger, above n 672, at 29.

${ }^{720}$ Baver and others, above n 136, at 42.
} 
individual titling. ${ }^{721}$ Bounding commons land frequently moves relational and locally specific interactions to more "impersonal, legal conventions." ${ }^{722}$ In this way, both systems would be conflicting, rather than complementing. With conflicting mechanisms of access, other circumstances would influence whether actors could gain access to swidden land. For example, in a situation where the SLM system does not recognise collective land holding, but rather issues individual titles, someone with greater political influence within a village may gain the individual title to land and begin to exercise the individual rights offered under the SLM to the detriment of fellow villagers, such as unilaterally selling sections of land.

(c) Application to swidden land in Myanmar

For customary land use rights over swidden land to be comprehensively recognised within Myanmar's SLM system, it would not be effective to move towards an individual titling system in areas where land is collectively held. Moreover, as swidden cultivation is practiced in the remote hilly areas of Myanmar, ${ }^{723}$ these areas are isolated, lack infrastructure and have limited socio-economic development. 724 They possess characteristics which make collective tenure more economically and socially viable than individual titles.

However, as the various change factors of market engagement, demographic growth and socio-cultural transition influence these areas, there will become greater pressure to move towards individualisation. Any of the SLM structures established to incorporate CLM systems will need to be flexible enough to transition into more individualised titles if community members want to pursue this.

(d) Different models for formalising customary communal tenure

Fitzpatrick outlines four main approaches regarding formalising customary communal tenure. They are the minimalist approach, the agency approach, incorporation of customary groups and the establishment of land boards. ${ }^{725}$ These approaches provide a spectrum of increasingly interventionist formalisation models. The minimalist approach merely maps the boundaries of communally owned land. However, it does not intervene in any way with the inner-workings of the group. Rather, traditional customary practices with regard to land rights continue to operate within the group. In the agency approach, the State empowers

\footnotetext{
${ }^{721}$ Transnational Institute, above n 604, at 34-35.

722 Mary Finley and Karl Offen "Bounding the commons: land demarcation in northeastern Nicaragua" (2009) 28 Bulletin of Latin American Research 343 at 344.

${ }^{723}$ Mertz and others, above n 2, at 284.

${ }^{724} \mathrm{Li}$ and others, above $\mathrm{n} 2$, at 1660.

${ }^{725}$ Fitzpatrick, above n 587, at 458.
} 
several members to become trustees who are able to act on behalf of the group. Group incorporation involves establishing a corporate structure governed by some form of constitution. The final model involves land boards being set up to oversee all matters in relation to land assets, such as transfers and mortgages. ${ }^{726}$

Fitzpatrick goes on to assess the four different types of communal formalisation models outlining their strengths and weaknesses as well as situations where they would perform optimally. Of the four models, the minimalist approach and group incorporation are most relevant to Myanmar's situation.

(e) Minimalist Approach

The minimalist approach is said to operate best in situations where customary practices are working effectively, there is little intra-group conflict and a land market has not developed. It is also effective where group survival and resource use is threatened by external encroachment. It is considered more politically palatable in situations where the incorporation of indigenous land rights into state law is a sensitive issue. However, it remains unclear how outsiders should deal with the group in relation to land matters. ${ }^{727}$ Lavigne Deville developed a similar model which recognised existing customary land rights in order to bring them into an inclusive, pluralistic system. ${ }^{728}$

(f) Incorporation of Customary Groups

Group incorporation uses its corporate structure and constitution to help prevent trustees from acting inappropriately. These structures can be used to ensure more equitable processes operate in relation to vulnerable members, such as women. As existing CLM systems can be undemocratic or discriminatory. ${ }^{729}$ However, if imposed structures are too different from existing structures, they may simply be ignored. ${ }^{730}$

(g) Which model is most appropriate

In circumstances where land transactions are rare, customary practices are strong and formalisation is for the purpose of protection from outsider encroachment, then it is best to have low intervention models such as social mapping. ${ }^{731} \mathrm{~A}$ minimalist approach would also allow localised diversity to be incorporated more naturally into a centralised structure. ${ }^{732}$ Conversely, where there are more transactions and existing customs are unable to adjust

\footnotetext{
726 At 458 .

727 At 458 .

${ }^{728}$ Deininger and others, above n 39, at 30-31.

${ }^{729}$ Rundstrom, above n 667, at 49.

${ }^{730}$ Fitzpatrick, above n 587, at 460-461.

731 At 470.

${ }^{732}$ Deininger and others, above n 39, at 32.
} 
to rapid social and economic changes, formalisation models which entail higher interventions in the form of legal structures or documentation are more appropriate.

(h) Examples of communal tenure models from the Philippines and Cambodia Cambodia takes the approach of incorporating a customary group. In order for land to be registered, an indigenous group must be approved and registered with the government as well as be incorporated. They are also required to draft internal rules to manage processes within the collective ownership structure. However, these are not required immediately. ${ }^{733}$ There are also regulations which enable community members to transition between individual and collective land use rights. For example, if a member chooses to separate from the collective and obtain individual title to land, a section of land will be carved out of the land or else the community will determine an amount of compensation to be paid to the member. Whereas, if a member chooses to become a part of the collective, they must relinquish their individual rights over the land and it becomes a part of the land under collective management. ${ }^{734}$

The Philippines follows more of the minimalist approach. There is a presumption that customarily held land will be collectively management. ${ }^{735}$ There is also no requirement to incorporate an indigenous group or draft internal rules. Rather, the consistent tenet of the legislation is to follow the particular customs or traditions of the indigenous group. ${ }^{736}$ For decisions to be made, group consensus is required. ${ }^{737}$ Once a CADT is issued, the jurisdiction of various government ministries over the area is extinguished. ${ }^{738}$

(i) Application to Myanmar

Swidden cultivation has persisted in remote and less developed areas in Myanmar ${ }^{739}$ and CLM systems appear relatively stable. In these areas, there would be few voluntary land transactions involving swidden land. Threats to swidden land use also appear to be external, such through concessions allocated to foreign companies or state organisations. ${ }^{740}$

\footnotetext{
733 Anderson, above n 18, at 20-23.

${ }^{734} \mathrm{Sub}$ decree on procedures of registration of land of indigenous communities 2009 (Cambodia), p 14.

735 Republic Act No 8371 (The Indigenous Peoples’ Rights Act) 1997 (Philippines), p 55.

${ }^{736}$ For example: subss 2(b), (f), 3(g) 7(b) (h) Republic Act No 8371 (The Indigenous Peoples' Rights Act).

737 Subsection 3(g), Republic Act No 8371 (The Indigenous Peoples' Rights Act); Office of the United Nations High Commissioner for Human Rights, above n 632, at 38.

${ }^{738}$ Republic Act No 8371 (The Indigenous Peoples’ Rights Act), subs 52(i).

${ }^{739} \mathrm{Li}$ and others, above $\mathrm{n} 2$, at 1660 .

740 Woods, above n 3 , at 6.
} 
Due to the complexity and length of time required to incorporate groups and draft internal rules, it appears most appropriate to initially formalise a collective tenure system in Myanmar in a low intervention system. The system would allow land boundaries to be more clearly established as well as allow the continuation of existing customary practices. However, it would enable swidden land, which could be facing external pressures, to be protected in the interim. Simply detailing existing land rights and processes has been viewed as a positive step towards tenure security. ${ }^{741}$

However, the legislation could allow for the movement towards an incorporated structure. This could allow organisations to work with local communities in drafting written internal rules and discussing whether they want to incorporate mechanisms for land within the collective to be individualised and vice versa. It could also enable discussion about how they should arrange any form of compensation payments for moving between forms of tenure. The Cambodian legislation allows only private or collective land holding. However, this would not necessarily allow for types of composite swidden, where farmers use a mixture of permanent and swidden cultivation depending on economic circumstances. Myanmar's legislation could include the ability to hold land both individually and collectively, with farmers being able to retain collective land rights as a form of 'insurance' so that they are able to support their families during periods of low commodity prices.

A potential method of registering collective land holding under the current SLM that is being researched is incorporating a village under the Association Law. As the implementing rules for the Association Law have not been issued, it was impossible to complete this research investigation. Notwithstanding, the pilot research programme made some major assumptions about whether it would be possible to register this land as Farmland once it had formed a legally recognised collective organisation. ${ }^{742}$ In a recent conference on the recognition of customary land rights in Myanmar, Obendorf mentioned that the current SLM system is not well-suited to cater for collective registration of land. ${ }^{743}$

Given the problems with incorporating collective land holding into the VFV or Farmland Laws, it would be best to include these provisions in the new National Land Law proposed by the draft NLUP. Although the draft NLUP recognises customary land use rights and CLM systems, it does not specifically mention collective land holding. This ought to be specifically recognised in any new legislation. Land could then be mapped and

\footnotetext{
${ }^{741}$ Deininger, above $\mathrm{n} 587$, at 8.

${ }^{742}$ Hunt, above n 555.

743 Robert Burton Oberndorf "Understanding How the Legal Framework in Myanmar Currently Supports Recognition of Communal Tenure" (National Dialogue on Customary Communal Land Tenure, Nay Pyi Taw, Myanmar, 14 February 2015).
} 
registered in the name of the particular village or group of villages which holds the land collectively and it could continue to be managed by the established village leadership. There could then be ongoing discussion with regard to incorporating the village and drafting internal rules based on customary practice. These rules could be renegotiated and amended as economic and social circumstances change in order to allow individual families to gain individual land title if they wish to do so. However, there would need to be clear guidelines as to how this was carried out in order to prevent coercion and undue influence from external parties. ${ }^{744}$

However, given the variance in CLM systems throughout Myanmar, the process of formalising collective land holding could look different for each village. In the Land Core Group's recent research into registering land collectively, village elite in Southern Chin State were unwilling to relinquish their rights of individual title and rental income through creating an association which would hold the land collectively. ${ }^{745}$ Hall et al warn against presuming collective ownership of land. ${ }^{746}$

$4 \quad$ Use of swidden land (whether swidden is able to be practiced in light of increasing development)

The use of a natural resource is intrinsically connected to access. In order to comprehensively access customarily held land, farmers must be able to choose how they use this resource, in particular whether they want to practice swidden cultivation on this land. Sturgeon describes the flexibility or 'plasticity' displayed by swidden farmers in adapting to changing circumstances. ${ }^{747}$ These characteristics could be utilised by administrative bodies in managing land use changes in these areas.

The main problem with the current SLM system in Myanmar is lack of clarity surrounding when or whether the use of swidden cultivation is permitted. The changing social and economic circumstances have also restricted swidden land use and reduced fallow periods. It is necessary to understand how to manage the use of swidden cultivation in the light of rapid economic and social development.

Traditional swidden cultivation has frequently been categorised alongside incipient swidden, which involves outside parties clearing and burning areas of original forest. ${ }^{748}$

\footnotetext{
744 This has been a significant problem in Cambodia. Jeff Vize and Manfred Hornung "Indigenous Peoples and Land Titling in Cambodia: A study of six villages" (paper presented to Annual World Bank Conference on Land and Poverty, Washington DC) at 3.

${ }^{745}$ Hunt, above n 555.

${ }^{746}$ Hall, Hirsch and Li, above n 52, at 45.

747 Sturgeon, above n 189, at 168.

${ }^{748}$ Mark Poffenberger "People in the forest: community forestry experiences from Southeast Asia" (2006) 5 International Journal of Environment and Sustainable Development 57 at 59-60.
} 
Because of this some Southeast Asian countries have banned swidden cultivation altogether. ${ }^{749}$ In Laos, this was accompanied by forced resettlement policies and has had severe economic and social consequences. 750

In Cambodia, swidden cultivation is permitted under s 25, Land Law 2001, as long as it is approved by administrative authorities. In the 2009 sub-decree on Procedures of Registration of Land of Indigenous Communities, it likewise permits the registration of swidden fallows and cultivated plots. ${ }^{751}$ It is also regulated under community forestry provisions. Under the Law on Forestry (2002) is able to be practiced during specific times of the year as determined in the Forestry Management Plan. ${ }^{752}$ The Cambodian phrase which is used to describe permissible swidden cultivation refers to traditional rotational cultivation, rather than incipient swidden which is undertaken on original forest land. ${ }^{753}$

(j) Managing development through free prior and informed consent (FPIC)

However, there is tension between maintaining swidden cultivation and implementing development projects in communities. The IPRA purports to protect traditional cultivation techniques such as swidden. ${ }^{754}$ Any change in traditional practices may only be brought about through the 'free prior and informed consent' of indigenous people groups concerned. ${ }^{755}$

This principle surrounding the treatment of indigenous peoples is increasingly used and recognised in both international and domestic legislation and judicial decisions. ${ }^{756} \mathrm{In}$ terms of the elements of FPIC, 'free' means that consent is "given voluntarily and absent of coercion, intimidation or manipulation." 757 'Prior' means "consent is sought sufficiently in advance of any authorization or commencement of activities." 758 'Informed' requires

\footnotetext{
749 Such as Laos and Vietnam Ducourtieux, Laffort and Sacklokham, above n 605, at 8; Ducourtieux and Castella, above n 605; Sithong Thongmanivong and others "Agrarian Land Use Transformation in Northern Laos: from Swidden to Rubber(<Special Issue>Land Use Changes in the Uplands of Southeast Asia: Proximate and Distant Causes)” (2009) 47 東南アジア研究 330.

${ }^{750}$ Baver and others, above n 136, at 93-95.

${ }^{751} \mathrm{Sub}$ decree on procedures of registration of land of indigenous communities 2009 (Cambodia), p article 6.

752 Royal Decree NS/RKM/0802/016 (Forestry Law) 2002 (Cambodia), p art 37; Kingdom of Cambodia "Community Forestry Sub-decree" <http://www.forestry.gov.kh/Documents/CF-Sub\%20Decree-Eng.pdf> at article 11; RECOFTC - The Center for People and Forests, above n 606.

753 Andersen, Sophorn and Thornberry, above n 600, at 28.

754 Republic Act No 8371 (The Indigenous Peoples’ Rights Act) 1997 (Philippines), s 3.

755 Republic Act No 8371 (The Indigenous Peoples’ Rights Act), s 58.

756 UN-REDD Programme Guidelines on Free, Prior andInformed Consent (2013) at 18.

757 At 18 .

758 At 19.
} 
clear, accessible, objective and ongoing information to be provided through the process. ${ }^{759}$ 'Consent' entails the "collective decision made by the rights-holders and reached through the customary decision-making processes of the affected peoples or communities." The seeking, granting or withholding of consent must be carried out in accordance with local customs. ${ }^{760}$

However, despite the comprehensive legal framework through which swidden land use may be identified, overall outcomes have been less than satisfactory. Land use in the IPRA is framed with reference to 'sustainability.' This has empowered NGOs and local government to restrict swidden use through regulation and indirect influence. Dressler describes how this discourse has led to shortened fallow periods and widespread demise of swidden on Palawan Island. 761

In general, FPIC has been usurped and indigenous peoples' consent in the Philippines has often been coerced and manipulated through improper processes. ${ }^{762}$ Many external factors, such as militarism, corruption, local government and NGO influence and business interests have prevented customary rights holders from fully obtaining the access offered to them through the SLM system. ${ }^{763}$

Issues are most likely to arise around development projects. This has been the case in the Philippines. ${ }^{764}$ The 2009 ICERD shadow report documents how development projects have been externally imposed on indigenous groups. ${ }^{765}$ Section 59 of the IPRA provides that indigenous groups must give free and prior informed and written consent (FPIC) before development projects are undertaken. However, this has been undermined through conducting FPIC procedures in contravention to customary practices, such as undermining representative groups, ${ }^{766}$ giving insufficient time to reach consensus ${ }^{767}$ and ignoring lack of consensus in decisions. ${ }^{768}$ FPIC has been reduced to a 'checklist' or ignored altogether. ${ }^{769}$ Insufficient information has been given to indigenous groups, in

\footnotetext{
759 At 19.

760 At 20.

${ }^{761}$ Dressler, above n 606.

762 Office of the United Nations High Commissioner for Human Rights, above n 632, at 36-38.

${ }^{763}$ Baver and others, above n 136, at 99; Office of the United Nations High Commissioner for Human Rights, above n 632; Dressler, above n 606.

${ }^{764}$ Office of the United Nations High Commissioner for Human Rights, above n 632, at 25.

765 At 32; also called “development aggression” At 33.

766 Office of the United Nations High Commissioner for Human Rights, above n 632, at 45.

76720 days At 36.

768 At 50.

${ }^{769}$ At 34.
} 
particular negative impacts of further stages of development projects have been withheld.

${ }^{770}$ Repetitive FPIC processes, which wear down community resistance until they relent to a development project, have been used. ${ }^{771}$ The transferability of FPIC by companies has also lead to abuses as later companies are immune from earlier failure. ${ }^{772}$ High-level corruption amongst ministerial decision-making bodies is a significant issue. ${ }^{773}$ Companies also use payments to community members so they will support projects, these payments are often deducted from future royalties payments. ${ }^{774}$ Companies have also been involved in paying for the registration of ancestral domains, circumventing traditional processes and leadership. ${ }^{775}$ These actions have undermined traditional institutions and customs, divided communities as well as destroying land and livelihoods. 776

On the other hand, some NGOs involved in development projects may be focused on conservationist outcomes. ${ }^{777}$ Walker coined the term 'arborealisation' referring to the process whereby upland communities are defined by and projects developed in terms of their relationship with forests, rather than considering whether they are more farmers than arborists. ${ }^{778}$ Development projects should not presume communities will have equivalent views about conservation as Western environmental groups.

(k) Proposed reforms

As it is currently unclear to what extent swidden cultivation is permissible under the draft NLUP, the legislation could include a non-exhaustive list of different types of customary land uses with swidden cultivation included as one of them.

It could also include specific provisions regarding the management of swidden cultivation in order to ensure it is practiced as part of traditional rotational swidden cultivation, rather than opportunistic incipient swidden by those outside the community. This could include labelling maps with areas left in rotational fallow and other areas that are left as original watershed forests.

Since the change of economic direction in 1988, the Myanmar government has been accused of favouring large foreign agribusiness companies at the expense of local

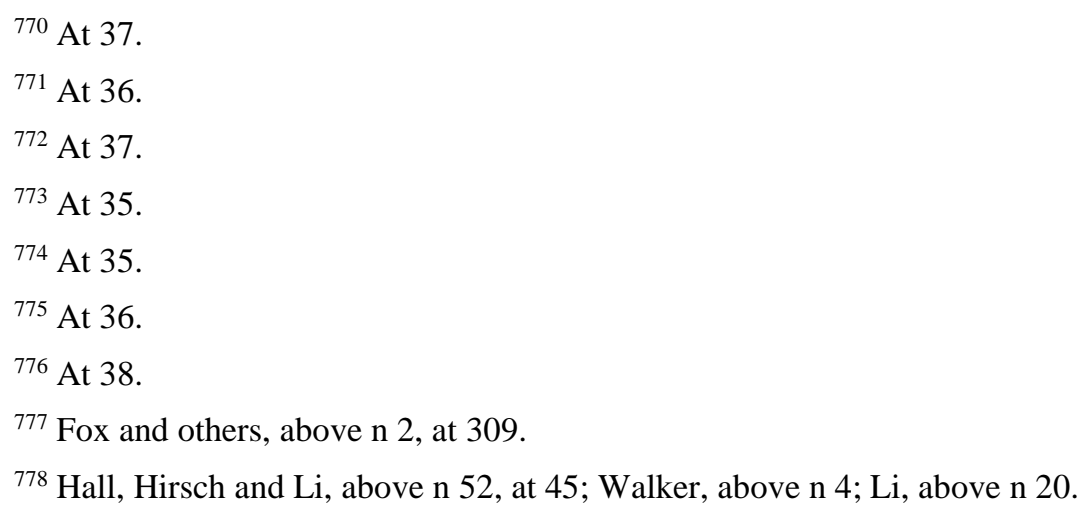


farmers. ${ }^{779}$ The movement towards mapping and defining boundaries in Myanmar is closely linked to economic development. Section 21 of the draft NLUP states:

[L]and tenure security [will be] the basic foundation for the systematic management of land use and rural and urban economic development by investment.

Given Myanmar's historical approach to economic development, there is concern that this process is making Myanmar's SLM system more secure for large business investors. Commentary on the draft NLUP has also criticised its favouring of large national and international investors and NGOs above small-holder farmers. ${ }^{780}$

In light of increased development in areas where land is customarily held, the principle of free, prior and informed consent (FPIC) should be incorporated into the legislation. Numerous groups have advocated for FPIC to be included in Myanmar's SLM system. ${ }^{781}$ The absence of FPIC in the draft NLUP was also noted and submissions have requested its inclusion. ${ }^{782}$ In the consultation meeting which occurred at the public release of the draft NLUP, the government agreed that FPIC should be included as part of the final NLUP. ${ }^{783}$

The inclusion of FPIC in Myanmar's SLM system would enable customary land holders to make decisions based on what they deem in their best interests. However, as shown in the case of the Philippines, the principle of FPIC must also be implemented in order to be effective. The inclusion of FPIC in legislation would provide the foundation for effective communication and mitigate the effects of external parties' alternative agendas. However, it provides little protection to customary land holders if it is not practically applied.

\footnotetext{
${ }^{779}$ Jones, above n 10.

780 TNI Myanmar Programme and TNI Agrarian Justice Programme, above n 31, at 21.

781 Dawei Development Association (DDA) and others Voices from the Ground: Concerns Over the Dawei Special Economic Zone and Related Projects (Dawei Development Association (DDA), 2014) at 6; Sekine, above n 514, at 10; Buchanan, Woods and Kramer, above n 317, at 44; Jasmine Burnley "A New Dawn for Equitable Growth in Myanmar? Making the private sector work for small-scale agriculture" (2013) 10 Oxfam Policy and Practice: Private Sector 63 at 8 and 10; Food Security Working Group, above n 516, at 3; Institute for Human Rights and Business, Myanmar for Responsible Business and The Danish Institute for Human Rights Myanmar Oil \& Gas Sector-Wide Impact Assessment (SWIA): Land (2014) at 100; Kramer and others, above n 133, at 15; OECD, above n 146, at 68-69; OXFAM Delivering Prosperity in Myanmar's Dryzone (OXFAM, 2014) at 4.

782 Ethnic Community Development Forum and the Customary Land Protection Committee Statement of Ethnic Community Development Forum and the Customary Land Protection Committee Concerning Myanmar's National Land Use Policy (Draft) (2014) at [10].

783 "Land Use Allocation and Scrutinizing Committee Consultation Meeting on Draft National Land Use Policy Minutes", above n 617.
} 


\section{$X$ Conclusion}

Myanmar's government is currently wrestling with how to integrate the diverse CLM systems controlling swidden land use with the SLM system. Much can be learned from the historical interaction between these two mechanisms of access as well as how other countries have dealt with this issue.

Although swidden cultivation is in a state of transition, it is important that underlying customary land use rights are effectively recognised in the SLM system. The drafting of the proposed National Land Law provides an ideal opportunity to reform areas of weakness within the current SLM system in its recognition of CLM systems.

There are many practical challenges to implementing the formalisation of CLM systems into the SLM system. However, formalisation will be most successful if the final outcome closely resembles the structures and processes under current CLM systems, while still allowing sufficient flexibility for change.

Some of the reforms proposed in this thesis will be relatively easy to implement, such as streamlining the terminology used for swidden cultivation. However, many other aspects will be more difficult and will require significant political will and financial investment. It is my hope that the SLM system and CLM systems in Myanmar will begin to complement, instead of conflict with, each other in order to enable swidden farmers to access their customarily held land into the future. 


\section{Legislation}

\section{Bibliography}

Royal Decree NS/RKM/0802/016 (Forestry Law) 2002 (kh).

Republic Act No. 8371 (The Indigenous Peoples’ Rights Act) 1997 (ph).

Constitution of the Republic of the Union of Myanmar 2008 (mm).

Royal Decree NS/RKM/0801/14 (Land Law) 2001 (kh).

Sub decree on procedures of registration of land of indigenous communities $2009(\mathrm{kh})$.

Duties and Rights of the Central Committee for the Management of Culturable Fallow Land and Waste Land 1991 (mm).

Procedures Conferring the Right to Cultivate Land / Right to Utilize Land for Agricultural and Livestock Breeding Purposes (Amendment) 1998 (mm).

Farmland Law 2012 (mm).

United Nations Declaration on the Rights of Indigenous Peoples(2007)GA Res 61/295, A/61/L.67 and Add.1.

Vacant, Fallow and Virgin Land Management Law 2012 (mm).

Farmland Rules 2012 (mm).

Vacant, Fallow and Virgin Land Management Rules 2012 (mm).

\section{Texts}

Gregory S Alexander and Eduardo Moisés Peñalver An Introduction to property theory (Cambridge University Press, Cambridge, 2012).

Alain Atangana, Damase Khasa, Scott Chang and Ann Degrande Tropical agroforestry (Springer, 2014).

Hla Tun Aung Myanmar: The Study of Processes and Patterns (National Centre for Human Resource Development, Publishing Committee, Ministry of Education, Myanmar, 2003).

Htin Aung Burmese Law Tales (Oxford University Press, 1962).

BH Baden-Powell The Land Systems of British India (Clarendon Press, Oxford, 1892) vol 3.

Lawrence C Becker Property Rights (Routledge, 2014). 
Fikret Berkes, Carl Folke and Johan Colding Linking Social and Ecological Systems (Cambridge University Press, 2000).

Ester Boserup The conditions of agricultural growth (Allen \& Unwin, London, 1965).

Sir Dietrich Brandis Report on the Teak Forests of Pegu, with a memorandum on the teak in the Tharawaddy Forests ... 1856 (Stationery Office, 1860).

Daniel W Bromley Environment and economy (Blackwell, Oxford, 1991).

Ian Brown Burma's economy in the twentieth century (Cambridge University Press, Cambridge, United Kingdom, 2013).

John W Bruce, Renée Giovarelli, Leonard Rolfes, David Bledsoe and Robert Mitchell Land law reform (World Bank, Washington, D.C, 2006).

Raymond L Bryant The political ecology of forestry in Burma, 1824-1994 (University of Hawai'i Press, Honolulu, 1997).

Burma Environmental Working Group Burma's environment (The Burma Environmental Working Group, Chiang Mai, 2011).

Richard Butwell U Nu of Burma (Stanford University Press, 1969).

Malcolm F Cairns (ed) Shifting Cultivation and Environmental Change (Routledge, 2015).

Mary P Callahan and East-West Center Washington Political authority in Burma's ethnic minority states (East-West Center, Washington, D.C., 2007).

David S Clark (ed) "Pluralism, Legal" in Encyclopedia of Law and Society: American and Global Perspectives (SAGE Publications, Thousand Oaks, CA, 2007) 1116.

Mark Cleary and Peter Eaton Tradition and reform (Oxford University Press, 1996).

Lorenzo Cotula Changes in Customary Land Tenure Systems in Africa (IIED, 2007).

Melissa Crouch and Timothy Lindsey (eds) Law, society and transition in Myanmar (Hart Publishing, Oxford, 2014).

Klaus W Deininger Land Policies for Growth and Poverty Reduction (World Bank Publications, 2003).

Peter Eaton Land Tenure, Conservation and Development in Southeast Asia (Routledge, 2013).

$\mathrm{K}$ Eberhardt "A review of challenges to sustainable development in the uplands of Myanmar" in Landscapes of Diversity: Indigenous Knowledge, Sustainable Livelihood and Resource Governance in Montane Mainland Southeast Asia Proceedings of the III Symposium on MMSEA 25-28 August 2002, Lijiang, PR China (2003) 101. 
RE Elson The end of the peasantry in Southeast Asia (MacMilllan Press, Houndmills (Hampshire), 1997).

John Sydenham Furnivall Colonial policy and practice (CUP Archive, 1956).

John Sydenham Furnivall An introduction to the political economy of Burma (Peoples' Literature Committee \& House, 1957).

Kinwun Mingyi U Gaung A Digest of the Burmese Buddhist Law (1893).

Lee Godden and Maureen Tehan (eds) Comparative perspectives on communal lands and individual ownership (Routledge, Abingdon, Oxon, England; New York, NY, 2010).

Derek Hall, Philip Hirsch and Tania Li Powers of exclusion (NUS Press, Singapore, 2011).

Godfrey Eric Harvey History of Burma from the Earliest Times to 10 March 1824 (Octagon Books, 1967).

Philip Hirsch and Carol Warren The Politics of Environment in Southeast Asia (Routledge, 2002).

MB Hooker Legal pluralism (Clarendon Press, 1975).

Andrew Huxley "Rajadhamma confronts Leviathan: Burmese political theoryin the 1870s" in Ian Harris (ed) Buddhism, Power and Political Order (Routledge, Oxon (England), 2007) 26.

Istituto Oikos and BANCA Myanmar Protected Areas: Context, Current Status and Challenges (Ancora Libri, Milano, Italy, 2011).

Martin Jelsma, Tom Kramer, Pietje Vervest, Transnational Institute and Burma Center Netherlands Trouble in the triangle (Silkworm Books, 2005).

Kristine Juul, Christian Lund and others Negotiating property in Africa. (Heinemann, 2002).

Edmund Ronald Leach Political systems of highland Burma (Athlone Press, London; Atlantic Highlands, NJ, 1986).

Scott Leckie and Ezekiel Simperingham Housing, land, and property rights in Burma (Displacement solutions : HLP Institute, Geneva, Switzerland, 2009).

Bertil Lintner Burma in Revolt (Silkworm Books, 1999).

Dr E Maung Expansion of Burmese law (Cornell University Press, 1951).

Maung Maung Bibliography and list of Dhammarthat in "Law and custom in Burma and the Burmese Family". 
Maung Maung and others Law and custom in Burma and the Burmese family (Springer, 1963).

Toon van Meijl and Franz von Benda-Beckmann Property Rights and Economic Development (Routledge, 1999).

Bruce Granville Miller Invisible Indigenes (University of Nebraska Press, 2003).

Stephen R Munzer A Theory of Property (Cambridge University Press, 1990).

Mya Than and Loong-Hoe Tan (eds) Myanmar dilemmas and options (ASEAN Economic Research Unit, Institute of Southeast Asian Studies, Singapore, 1990).

Tun Myint "A Perspective on Burma" in Advancing Environmental Governance: Perspectives from the Regional Environmental Forum for Mainland Southeast Asia (2003).

John Nisbet Burma under British rule - and before (Archibald Constable, Westminster, 1901) vol 1.

John Nisbet Burma under British rule - and before (Archibald Constable, Westminster, 1901) vol 2.

Meine van Noordwijk, Elok Mulyoutami, Niken Sakuntaladewi and Fahmuddin Agus Swiddens in transition (World Agroforestry Centre, Bogor (Indonesia), 2008).

OECD Multi-dimensional Review of Myanmar (Organisation for Economic Co-operation and Development, Paris, 2013).

OECD OECD Investment Policy Reviews (Organisation for Economic Co-operation and Development, Paris, 2014).

Ikuko Okamoto and Ajia Keizai Kenkyūjo (Japan) Economic disparity in rural Myanmar (IDE-JETRO : NUS Press, Singapore, 2008).

Peter Ørebech, Fred Bosselman, Jes Bjarup, David Callies, Martin Chanock and Hanne Petersen The Role of Customary Law in Sustainable Development (Cambridge University Press, Cambridge (UK), 2005).

Nancy Lee Peluso Rich Forests, Poor People (University of California Press, 1994).

Nancy Lee Peluso and Christian Lund New Frontiers of Land Control (Routledge, 2013).

Giacomo Rambaldi Participatory Three-dimensional Modelling: Guiding Principles and Applications (2010 edition ed, ACP-EU Technical Centre for Agricultural and Rural Cooperation (CTA, Wageningen, the Netherlands, 2010).

A Terry Rambo, Trọng Cúc Lê, Deanna Donovan and East-West Center Development trends in Vietnam's northern mountain region (East-West Center, Program on Environment, 1996). 
Rajkumari Chandra Kalindi Roy Land rights of the indigenous peoples of the Chittagong Hill Tracts, Bangladesh (Iwgia, 2000).

Robert David Sack Human Territoriality (CUP Archive, 1986).

Lian H Sakhong and Nordic Institute of Asian Studies In search of Chin identity (NIAS Press, Copenhagen S., Denmark, 2003).

Klot Sarem, Jeremy Ironside and Georgia Van Rooijen "Understanding and Using Community Maps Among Indigenous Communities in Ratanakiri Province, Cambodia" in Jefferson Fox, Krisnawati Suryanata and Peter Hershock (eds) Mapping Communities: Ethics, Values, Practice (East-West Center, Honolulu, Hawai'i, 2005) 43.

James C Scott The art of not being governed (Yale University Press, New Haven, 2009).

Monique Skidmore and Trevor Wilson (eds) Myanmar (Asia Pacific Press and Australian National University E Press, Canberra, 2007).

Martin J Smith Paradise lost? (Article 19, London, UK, 1994).

Martin John Smith Burma (University Press, 1991).

Hernando de Soto Mystery of Capital: Why Capitalism Triumphs in the West and Fails Everywhere Else (Basic Books, 2003).

Ashley South, Maria Katsabanis and Centre on Housing Rights and Evictions Displacement and disposession forced migration and land rights in Burma (COHRE, Geneva, 2007).

Joseph Earle Spencer Shifting Cultivation in Southeastern Asia (University of California Press, 1966).

HNC Stevenson The Economics of the Central Chin Tribes (Greg Press Limited, England, 1968).

Brian Z Tamanaha A General Jurisprudence of Law and Society (Oxford University Press, 2001).

Robert H Taylor The state in Myanmar (Hurst, London, 2009).

Thailand Burma Border Consortium Internal displacement and protection in Eastern Burma (Thailand Burma Border Consortium, 2005).

Burmese Border Consortium (Thailand) Reclaiming the right to rice (Burmese Border Consortium, 2003).

Thant Myint-U The making of modern Burma (Cambridge University Press, New York, 2001). 
Ardeth Maung Thawnghmung Behind the teak curtain (Kegan Paul Limited, London; New York, 2004).

Myat Thein Economic Development of Myanmar (Institute of Southeast Asian Studies, 2004).

Camilla Toulmin, Philippe Lavigne Delville and Samba Traoré (eds) The dynamics of resource tenure in West Africa (GRET; IIED, Paris : London, 2002).

Jeremy Waldron The Right to Private Property (Clarendon Press, 1990).

Kan Zaw, NuNu Lwin, Khin Thida Nyein and Mya Thandar "Agricultural Transformations, Institutional Changes and Rural Development in Ayeyarwady Delta, Myanmar" in PS Intal, S Oum and MJO Simorangkir (eds) Agricultural Development, Trade and Regional Cooperation in Developing East Asia (ERIA, Jakarta, 2011).

\section{Journal Articles}

Daniel Adler and Jeremy Ironside "Mapping Indigenous Communal Lands: A Review of the Literature from a Cambodian Perspective" [2009].

Arun Agrawal and Elinor Ostrom "Collective Action, Property Rights, and Decentralization in Resource Use in India and Nepal" (2001) 29 Politics Society 485.

Kirsten Ewers Andersen, Sek Sophorn and Francesca Thornberry "Development of a Subdecree on Shifting Cultivation under Article 37 of the Forestry Law (2002), Cambodia" [2007] ILO and Danida 11.

Hla Aung "Burmese Concept of Law" (1969) 52 Journal of the Burma Research Society 27.

Franz von Benda-Beckmann "Anthropological Approaches to Property Law and Economics" [1995] European Journal of Law and Economics.

Peter Boomgaard "Long-Term Changes in Land-Tenure Arrangements in Pre-Modern and Early-Modern Southeast Asia: An Introduction" (2011) 54 Journal of the Economic \& Social History of the Orient 447.

J Peter Brosius, Anna Lowenhaupt Tsing and Charles Zerner "Representing communities: Histories and politics of community-based natural resource management" (1998) 11 Society \& Natural Resources 157.

Thilde Bech Bruun, Andreas de Neergaard, Deborah Lawrence and Alan D Ziegler "Environmental Consequences of the Demise in Swidden Cultivation in Southeast Asia: Carbon Storage and Soil Quality" (2009) 37 Human Ecology 375.

Raymond L Bryant "Shifting the Cultivator: The Politics of Teak Regeneration in Colonial Burma” (1994) 28 Modern Asian Studies 225. 
Raymond L Bryant "The Greening of Burma: Political Rhetoric or Sustainable Development?” (1996) 69 Pacific Affairs 341.

Jasmine Burnley "A New Dawn for Equitable Growth in Myanmar? Making the private sector work for small-scale agriculture" (2013) 10 Oxfam Policy and Practice: Private Sector 63.

Derek Byerlee "The Fall and Rise Again of Plantations in Tropical Asia: History Repeated?” (2014) 3 Land 574.

Nyein Chan, Shinya Takeda, Reiji Suzuki and Sota Yamamoto "Establishment of allometric models and estimation of biomass recovery of swidden cultivation fallows in mixed deciduous forests of the Bago Mountains, Myanmar" (2013) 304 Forest Ecology and Management 427.

Marcus Colchester "Indigenous peoples and communal tenures in Asia" (2004) 1 Land Reform 28.

Harold C Conklin and others "Hanunoo agriculture. A report on an integral system of shifting cultivation in the Philippines. Vol. 2." [1957] For Devel Pap 12 FAO.

RA Cramb, Carol J Colfer, Pierce, Wolfram Dressler, Pinkaew Laungaramsri, Quang Trang Le, Elok Mulyoutami, Nancy L Peluso and Reed L Wadley "Swidden Transformations and Rural Livelihoods in Southeast Asia" (2009) 37 Human Ecology 323.

Klaus Deininger “Land policies and land reform” [2004] World Bank, Washington.

Harold Demsetz "Toward a Theory of Property Rights" (1967) 57 The American Economic Review 347.

Wolfram Dressler "Green governmentality and swidden decline on Palawan Island" (2014) 39 Transactions of the Institute of British Geographers 250.

Olivier Ducourtieux, Jean-Richard Laffort and Silinthone Sacklokham "Land policy and farming practices in Laos" (2005) 36 Development and Change 499.

Roy Ellen "Studies of Swidden Agriculture in Southeast Asia since 1960: An Overview and Commentary on Recent Research and Syntheses" (2012) 3 Asia Pacific World 18.

Jane M Ferguson "The scramble for the Waste Lands: Tracking colonial legacies, counterinsurgency and international investment through the lens of land laws in Burma/Myanmar: Burma/Myanmar Waste Lands" (2014) 35 Singapore Journal of Tropical Geography 295.

Mary Finley and Karl Offen "Bounding the commons: land demarcation in northeastern Nicaragua" (2009) 28 Bulletin of Latin American Research 343. 
Daniel Fitzpatrick “'Best Practice' Options for the Legal Recognition of Customary Tenure" (2005) 36 Development and Change 449.

Jefferson Fox "Siam Mapped and Mapping in Cambodia: Boundaries, Sovereignty,and Indigenous Conceptions of Space” (2002) 15 Society \& Natural Resources 65.

Jefferson Fox and Jean-Christophe Castella "Expansion of rubber (Hevea brasiliensis) in Mainland Southeast Asia: what are the prospects for smallholders?" (2013) 40 Journal of Peasant Studies 155.

Jefferson Fox, Jean-Christophe Castella and Alan D Ziegler "Swidden, rubber and carbon: Can REDD+ work for people and the environment in Montane Mainland Southeast Asia?" Global Environmental Change.

Jefferson Fox, Yayoi Fujita, Dimbab Ngidang, Nancy Peluso, Lesley Potter, Niken Sakuntaladewi, Janet Sturgeon and David Thomas "Policies, Political-Economy, and Swidden in Southeast Asia” (2009) 37 Human Ecology 305.

Jefferson Fox, Dao Minh Truong, A Terry Rambo, Nghiem Phuong Tuyen, Stephen Leisz and others "Shifting cultivation: a new old paradigm for managing tropical forests" (2000) 50 BioScience 521.

Stefano Di Gessa, P Poole and T Bending "Participatory mapping as a tool for empowerment: Experiences and lessons learned from the ILC network" [2008] Rome: ILC/IFAD.

Garrett Hardin "The tragedy of the commons" (1968) 162 science 1243.

Michael A Heller “The Boundaries of Private Property" (1999) 108 The Yale Law Journal 1163.

Andrew Huxley "Buddhism and Law-The View From Mandalay" (1995) 18 Journal of the International Association of Buddhist Studies 47.

Andrew Huxley "The Importance of the Dhammathats in Burmese Law and Culture" (1997) 1 Journal of Burma Studies 1.

Isabel Inguanzo “Indigenous Peoples' Rights in Southeast Asia” (2014) 22 Asian Journal of Political Science 45.

Jay T Johnson, Renee Pualani Louis and Albertus Hadi Pramono "Facing the future: Encouraging critical cartographic literacies in indigenous communities" (2006) 4 ACME: an international e-journal for critical geographies 80 .

Lee Jones "The Political Economy of Myanmar's Transition" (2014) 44 Journal of Contemporary Asia 144.

Jake Kosek "Mapping politics” (1998) 45 The Common Property Resource Digest 4. 
Khin Maung Kyi "Modernization of Burmese Agriculture: Problems and Prospects" [1982] Southeast Asian Affairs 115.

Kim Kyung-Ryang and Jemal Abafita "Agricultural Development in Myanmar: Lessons from Korean Experience” (2012) 24 Korean J Intl Agri 136.

Sai Latt and Robin Roth "Agrarian Change and Ethnic Politics: Restructuring of Hmong and Shan Labour and Agricultural Production in Northern Thailand" [2014] Journal of Agrarian Change.

Peter Leimgruber, Daniel S Kelly, Marc K Steininger, Jake Brunner, Thomas Mueller and Melissa Songer "Forest cover change patterns in Myanmar (Burma) 1990-2000" (2005) 32 Environmental Conservation 356.

Chenhua Liao, Zhiming Feng, Peng Li and Xiaona Liu "The spatio-temporal variation of shifting cultivation in the border region of Myanmar, Laos and Thailand" (2014) 8 地理研 究 13 .

Peng Li, Zhiming Feng, Luguang Jiang, Chenhua Liao and Jinghua Zhang "A Review of Swidden Agriculture in Southeast Asia” (2014) 6 Remote Sensing 1654.

Tania Murray Li "Engaging Simplifications: Community-Based Resource Management, Market Processes and State Agendas in Upland Southeast Asia" (2002) 30 World Development 265.

Tania Murray Li "Indigeneity, Capitalism, and the Management of Dispossession” (2010) 51 Current Anthropology 385.

Tanya Murray Li "Masyarakat Adat, Difference, and the Limits of Recognition in Indonesia's Forest Zone” (2001) 35 Modern Asian Studies 645.

Xiaona Liu, Zhiming Feng, Luguang Jiang, Peng Li, Chenhua Liao, Yanzhao Yang and Zhen You "Rubber plantation and its relationship with topographical factors in the border region of China, Laos and Myanmar” (2013) 23 J Geogr Sci 1019.

Zhe Li and Jefferson Fox "Mapping rubber tree growth in mainland Southeast Asia using time-series MODIS 250 m NDVI and statistical data” (2012) 32 Applied Geography 420.

Chuthatip Maneepong and Chung-Tong Wu "Comparative borderland developments in Thailand" (2004) 21 ASEAN Economic Bulletin 135.

Tin Min Maung and Miho Yamamoto "Exploring the Socio-Economic Situation of Plantation Villagers: A Case Study in Myanmar Bago Yoma" (2008) 7 Small-scale Forestry 29.

Nicholas Menzies "Three hundred years of taungya: A sustainable system of forestry in south China" (1988) 16 Human Ecology 361. 
Francesca Merlan “Indigeneity: Global and Local” (2009) 50 Current Anthropology 303.

Sally Engle Merry “Legal Pluralism” (1988) 22 Law \& Society Review 869.

Ole Mertz "The relationship between length of fallow and crop yields in shifting cultivation: a rethinking” (2002) 55 Agroforestry systems 149.

Ole Mertz, Stephen J Leisz, Andreas Heinimann, Kanok Rerkasem, Thiha, Wolfram Dressler, Van Cu Pham, Kim Chi Vu, Dietrich Schmidt-Vogt, Carol J Colfer, P, Michael Epprecht, Christine Padoch and Lesley Potter "Who Counts? Demography of Swidden Cultivators in Southeast Asia" (2009) 37 Human Ecology 281.

Ole Mertz, Christine Padoch, Jefferson Fox, RA Cramb, Stephen J Leisz, Nguyen Thanh Lam and Tran Duc Vien "Swidden Change in Southeast Asia: Understanding Causes and Consequences" (2009) 37 Human Ecology 259.

Myat Su Mon, Nobuya Mizoue, Naing Zaw Htun, Tsuyoshi Kajisa and Shigejiro Yoshida "Factors affecting deforestation and forest degradation in selectively logged production forest: A case study in Myanmar" (2012) 267 Forest Ecology and Management 190.

U Myint Aung “Policy and practice in Myanmar's protected area system" (2007) 84 Journal of Environmental Management 188.

Dominic Nardi "Discipline-flourishing Constitutional Review: A Legal and Political Analysis of Myanmar's New Constitutional Tribunal" (2010) 12 Australian Journal of Asian Law 1.

Harold Olofson "Swidden and kaingin among the Southern Tagalog: A problem in Philippine upland ethno-agriculture" (1980) 8 Philippine Quarterly of Culture and Society 168.

Christine Padoch, Kevin Coffey, Ole Mertz, Stephen J Leisz, Jefferson Fox and Reed L Wadley "The Demise of Swidden in Southeast Asia? Local Realities and Regional Ambiguities" (2007) 107 Geografisk Tidsskrift-Danish Journal of Geography 29.

Nancy Lee Peluso "Whose Woods Are These? Counter-Mapping Forest Territories in Kalimantan, Indonesia" (1995) 27 Antipode 383.

Nancy Lee Peluso and Peter Vandergeest "Genealogies of the political forest and customary rights in Indonesia, Malaysia, and Thailand" (2001) 60 The Journal of Asian Studies 761.

Mark Poffenberger "People in the forest: community forestry experiences from Southeast Asia" (2006) 5 International Journal of Environment and Sustainable Development 57.

PS Ramakrishnan and OP Toky "Soil nutrient status of hill agro-ecosystems and recovery pattern after slash and burn agriculture (Jhum) in north-eastern India" (1981) 60 Plant Soil 41. 
Giacomo Rambaldi, Sahlee Bugna, Angela Tiangco and Dave de Vera "Bringing the vertical dimension to the negotiating table" (2002) 2 Preliminary assessment of a conflict resolution case in the Philippines ASEAN Biodiversity 17.

A Terry Rambo "The composite swiddening agroecosystem of the Tay ethnic minority of the northwestern mountains of Vietnam" [1998] Land Degradation and Agricultural Sustainability: Case Studies from Southeast and East Asia, Regional Secretariat, The Southeast Asian Universities Agroecosystem Network (SUAN) Khon Kaen University, Khon Kaen 43.

Anu Rammohan and Bill Pritchard "The Role of Landholding as a Determinant of Food and Nutrition Insecurity in Rural Myanmar" (2014) 64 World Development 597.

Andrzej Rapaczynski "The roles of the state and the market in establishing property rights" [1996] The Journal of Economic Perspectives 87.

G Rasul and GB Thapa "Shifting cultivation in the mountains of South and Southeast Asia: regional patterns and factors influencing the change" (2003) 14 Land Degradation \& Development 495.

Kanok Rerkasem and Benjavan Rerkasem "Montane Mainland South-East Asia: agroecosystems in transition” (1995) 5 Global Environmental Change 313.

Jesse C Ribot and Nancy Lee Peluso “A Theory of Access” (2003) 68 Rural sociology 153.

Jonathan Rigg "Poverty and livelihoods after full-time farming: A South-East Asian view" (2005) 46 Asia Pacific Viewpoint 173.

Robin Roth "The challenges of mapping complex indigenous spatiality: from abstract space to dwelling space" (2009) 16 Cultural Geographies 207.

Robert A Rundstrom "GIS, indigenous peoples, and epistemological diversity" (1995) 22 Cartography and geographic information systems 45.

Teruko Saitõ "Farm Household Economy Under Paddy Delivery System in Contemporary Burma” (1981) 19 The Developing Economies 396.

Nilmini Senavirathna Saumya, Wityi Hnin and Fujino Takeshi "Community knowledge and attitude towards regional developmental requirements in remote townships of Chin state, Myanmar" (2014) 2014 International Journal of Human Culture Studies 25.

Edella Schlager and Elinor Ostrom "Property-Rights Regimes and Natural Resources: A Conceptual Analysis" (1992) 68 Land Economics 249.

Dietrich Schmidt-Vogt, Stephen J Leisz, Ole Mertz, Andreas Heinimann, Thiha Thiha, Peter Messerli, Michael Epprecht, Pham Van $\mathrm{Cu}, \mathrm{Vu}$ Kim Chi, Martin Hardiono and Truong M Dao "An Assessment of Trends in the Extent of Swidden in Southeast Asia" (2009) 37 Human Ecology 269. 
Roy C Sidle, Alan D Ziegler and John B Vogler "Contemporary changes in open water surface area of Lake Inle, Myanmar" (2007) 2 Sustain Sci 55.

Renee Sieber "Public Participation Geographic Information Systems: A Literature Review and Framework" (2006) 96 Annals of the Association of American Geographers 491.

Win Win Soe "Land and Society: The Changes of Land Utilization and Lifestyle in Waphyudaung Village Tract, Yamethin Township, Myanmar" Universities Research Journal 455.

Janet C Sturgeon "Border Practices, Boundaries, and the Control of Resource Access: A Case from China, Thailand and Burma" (2004) 35 Development and Change 463.

Janet C Sturgeon and Thomas Sikor "Post-socialist Property in Asia and Europe: Variations on Fuzziness" (2004) Volume 2 Conservation and Society 1.

Yogeswaran Subramaniam "The ASEAN human rights declaration and indigenous rights" (2013) 8 ILB 3.

Endah Sulistyawati, Ian R Noble and Michael L Roderick "A simulation model to study land use strategies in swidden agriculture systems" (2005) 85 Agricultural Systems 271.

Akio Takahashi "Swiddens, Rice Terraces, and Malay Connections:Resource Use and Socio-economic Strata in the Chin Hills, Myanmar” (2007) 45 東南アジア研究 404.

Kirk Talbott, John Waugh and Douglas Batson “A U.S. Asian-Pacific Pivot Point: Burma's Natural Resources” (2013) 4 Prism : a Journal of the Center for Complex Operations 110.

Yukako Tani "Ecological Factors Affecting Taungya Farmers Behavior in Teak Plantation Projects: A Case Study in Bago Range, Union of Myanmar.” (2000) 10 Tropics 273.

Mya Than "Little Change in Rural Burma: A Case Study of a Burmese Village (1960-80)" (1987) 2 Sojourn: Journal of Social Issues in Southeast Asia 55.

Tin Maung Maung Than "MYANMAR in 2008: Weathering the Storm" (2009) 2009 Southeast Asian Affairs 195.

Myat Thein "The Economics of Farm Size and Land Policy in the Transition to a Market Economy" (1997) 12 Sojourn: Journal of Social Issues in Southeast Asia 124.

Patricia Thompson "Philippines Indigenous Peoples Rights Act" (1999) 10 Colo J Int'l Envtl L \& Pol'y 179.

Sithong Thongmanivong, Yayoi Fujita, Khamla Phanvilay and Thoumthone Vongvisouk "Agrarian Land Use Transformation in Northern Laos: from Swidden to Rubber $<$ Special Issue>Land Use Changes in the Uplands of Southeast Asia: Proximate and Distant Causes)” (2009) 47 東南アジア研究 330. 
Bill Threlkeld, Mac Chapin and Zachary Lamb "Mapping indigenous lands" (2005) 34 Annu Rev Anthropol 619.

Kyaw Tint, Oliver Springate-Baginski, Duncan Macqueen and Mehm Ko Ko Gyi "Unleashing the potential of community forest enterprises in Myanmar."

Michael Trebilcock and Paul-Erik Veel "Property Rights and Development: The Contingent Case for Formalization" (2008) 30 U Pa J Int'1 L 397.

Peter Vandergeest and Nancy Lee Peluso "Territorialization and state power in Thailand" (1995) 24 Theory and society 385.

Nathalie Van Vliet, Ole Mertz, Andreas Heinimann, Tobias Langanke, Unai Pascual, Birgit Schmook, Cristina Adams, Dietrich Schmidt-Vogt, Peter Messerli, Stephen Leisz, JeanChristophe Castella, Lars Jørgensen, Torben Birch-Thomsen, Cornelia Hett, Thilde BechBruun, Amy Ickowitz, Kim Chi Vu, Kono Yasuyuki, Jefferson Fox, Christine Padoch, and others "Trends, drivers and impacts of changes in swidden cultivation in tropical forestagriculture frontiers: A global assessment" (2012) 22 Global Environmental Change 418.

N Van Vliet, O Mertz, T Birch-thomsen and B Schmook "Is There a Continuing Rationale for Swidden Cultivation in the 21st Century?” (2013) 41 Human Ecology 1.

Andrew Walker "Seeing farmers for the trees: Community forestry and the arborealisation of agriculture in northern Thailand" (2004) 45 Asia Pacific Viewpoint 311.

Nathan Willis "Land disputes and the ongoing development of the substantive rule of law in Myanmar (Burma)" [2013].

Kevin Woods "Ceasefire capitalism: military-private partnerships, resource concessions and military-state building in the Burma-China borderlands" (2011) 38 Journal of Peasant Studies 747.

Alexandra Xanthaki "Land Rights of Indigenous Peoples in South-East Asia" (2003) 4 Melb J Int'l L 467.

Jianchu Xu, R Edward Grumbine and Philip Beckschäfer "Landscape transformation through the use of ecological and socioeconomic indicators in Xishuangbanna, Southwest China, Mekong Region” (2014) 36 Ecological Indicators 749.

AD Ziegler, JM Fox and J Xu "The Rubber Juggernaut” (2009) 324 Science 1024.

\section{Other secondary documents}

"BURMA: Draft land law denies basic rights to farmers" Asian Human Rights Commission.

J Baver, B Jonveaux, R Ju, K Kitamura, P Sharma, L Wade and S Yasui Securing Livelihoods and Land Tenure in Rural Myanmar (2013). 
Forestry Department, Food and Agriculture Organization of the United Nations Global Forest Resources Assessment 2010 Country Report: Myanmar (FRA2010/141 2010).

Jefferson Fox, Jean-Christophe Castella, Alan D Ziegler and Sidney B Westley Rubber plantations expand in mountainous Southeast Asia: what are the consequences for the environment? (2014).

Japan International Cooperation Agency, RECS International Inc, Oriental Consultants Co Ltd and Nippon KOEI Co Ltd Preparatory Survey for the Integrated Regional Development for Ethnic Minorities in the South-East Myanmar - Final Report (EI JR 13199 2013).

Office of the United Nations High Commissioner for Human Rights Philippines Indigenous Peoples ICERD Shadow Report (2009).

Ikuko Okamoto, Kyosuke Kurita, Takashi Kurosaki and Koichi Fujita Rich Periphery, Poor Center: Myanmar's Rural Economy under Partial Transition to Market Economy (2003).

Union of Myanmar, Ministry of Forestry Third National Report to the UNCCD (2006).

Ei Ei Swe Hlaing "Facilitating Decentralized Policy for Sustainable Forest Governance in Myanmar: Lessons from the Philippines" (Thesis, 2013).

Toe Hla "Money-lending and contractual thet-kayits: A socio-economicpattern of the later Kon-baung period, 1819-1885.”

Ma Khin Mya "The Impact of Traditional Culture and Environmental Forces on the Development of the Kachins, a Sub-cultural Group of Burma" (University of Maryland, College Park., 1961).

Janet Carol Sturgeon "Practices on the Periphery: Marginality, Border Powers, and Land Use in China and Thailand" (Candidacy for the Degree of Doctor of Forestry and Environmental Studies, Yale University, 2000).

Displacement Solutions "Myanmar at the HLP Crossroads: Proposals for Building an Improved Housing, Land and Property Rights Framework that Protects the People and Supports Sustainable Economic Development" (October 2012) <http://displacementsolutions.org/files/documents/MyanmarReport.pdf>.

Nancy Hudson-Rodd, Myo Nyunt, Saw Thamain Tun and Sein Htay "The impact of the confiscation of land, labor, capital assets and forced relocation in Burma by the military regime" (2003) NCUB/FTUB discussion paper <http://www.burmalibrary.org/docs/land_confiscation1-20.pdf>.

Kingdom of Cambodia "Community Forestry Sub-decree" <http://www.forestry.gov.kh/Documents/CF-Sub\%20Decree-Eng.pdf>. 
Livelihoods and Food Security Trust Fund "LIFT Baseline Survey Report" (July 2012) $<$ http://archive.lift-fund.net/downloads/LIFT\%20Baseline\%20Survey\%20Report\%20$\% 20 J u l y \% 202012$.pdf $>$.

Myanmar News Agency "Pyithu Hluttaw session continues for 48th day One proposal discussed, information to enlist given, formation of commission submitted, approval for one bill sought" (17 November 2011) <http://www.burmalibrary.org/docs12/PHNLM2011-11-17.pdf>.

"Land Use Allocation and Scrutinizing Committee Consultation Meeting on Draft National Land Use Policy Minutes" (18 October 2014) <http://www.burmalibrary.org/docs19/Draft_National_Land_Use_Policy_PreConsulation_18_Oct-Minutes-en.pdf>.

Randy Abeto, Zeff Calilung, Joan Pauline Talubo and Benny Cumatang "Community Mapping in the Philippines: A Case Study on the Ancestral Domain Claim of the Higaonons in Impasug-ong, Bukidnon" (paper presented to Regional Community Mapping Network Workshop, Quezon City, Philippines).

SJ Anaya Report of the Special Rapporteur on the rights of indigenous peoples, James Anaya, on the consultation on the situation of indigenous peoples in Asia(2013).

Kirsten Ewers Anderson Communal Tenure and the Governance of Common Property Resources in Asia: Lessons from Experiences in Selected Countries(Food and Agriculture Organization of the United Nations, 2011).

John Buchanan, Kevin Woods and Tom Kramer Developing Disparity: Regional investment in Burma's Borderlands(Transnational Institute).

Tony Burns Land Administration Reform: Indicators of Success and Future Challenges(World Bank, 2007).

Tony Burns, Chris Grant, Kevin Nettle, Anne-Marie Brits and Kate Dalrymple Land administration reform: indicators of success and future challenges(World Bank, 2007).

Jairo G Castano (ed) Thematic Papers on Myanmar Census of Agriculture 2010(2013).

Dawei Development Association (DDA), Robert Finch, Alex Moodie, Rebeca Leonard, Luntharimar Longcharoen, Jessica Armour, Ratawit Ouprachanon and Areewan Sombunwattanakun (eds) Voices from the Ground: Concerns Over the Dawei Special Economic Zone and Related Projects.(Dawei Development Association (DDA), 2014).

Klaus W Deininger, Clarissa Augustinus, Stig Enemark and Paul Munro-Faure (eds) "Innovations in land rights recognition, administration, and governance" in Joint Organizational Discussion Paper - Issue 2 (World Bank Publications, paper presented to The Annual Conference on Land Policy and Administration, 2010). 
Displacement Solutions Land Rights and Mine Action in Myanmar(Displacement Solutions, 2014).

Olivier Ducourtieux and Jean-Christophe Castella "Land reforms and impact on land use in the uplands of Vietnam and Laos: Environmental protection or poverty alleviation" in Colloque international "Les frontières de la question foncière-At the frontier of land issues”, Montpellier (2006).

K Eberhardt Farmer Field School for Sustainable Development in MyanmarUpland Project in Sadung and PaO Regions: Report of Mid-term Review(Metta Development Foundation, 2006).

Ethnic Community Development Forum and the Customary Land Protection Committee Statement of Ethnic Community Development Forum and the Customary Land Protection Committee Concerning Myanmar's National Land Use Policy (Draft)(2014).

Food Security Working Group Land Tenure: A foundation for food security in Myanmar's uplands(Food Security Working Group, 2010).

Food Security Working Group Upland Land Tenure Security in Myanmar: An overview(Food Security Working Group, 2011).

Food Security Working Group Submission for the Revisions to the Draft Myanmar Farmers Rights Protection Law(Food Security Working Group, 2013).

Government of the Republic of the Union of Myanmar Land Use Allocation and Scrutinizing Committee National Land Use Policy (English)(2014).

Government of the Republic of the Union of Myanmar Land Use Allocation and Scrutinizing Committee National Land Use Policy (Myanmar)(2014).

Steven Haggblade, Duncan Boughton, Glenn Denning, Renate Kloeppinger-Todd, Khin Mar Cho, Shannon Wilson, Larry CY Wong, Zaw Oo, Tin Maung Than, Naw Eh Mwee Aye Wai, Ngu Wah Win and Tun Min Sandar A Strategic Agricultural Sector and Food Security Diagnostic for Myanmar(USAID, MSU and MDRI/CESD, 2013).

Giles Henley Case study on land in Burma(Overseas Development Institute (ODI), 2014).

Philip Hirsch "Titling against grabbing? Critiques and conundrums around land formalisation in Southeast Asia" in International Conference on Global Land Grabbing (2011).

Glenn Hunt "Mapping of rotational and fallow taungya lands in Chin and Shan States" (ECODEV Customary Tenure Mapping Workshop, Yangon, 4 February 2015).

Institute for Human Rights and Business, Myanmar for Responsible Business and The Danish Institute for Human Rights Myanmar Oil \& Gas Sector-Wide Impact Assessment (SWIA): Land(2014). 
International Labour Organisation Convention concerning Indigenous and Tribal Peoples in Independent Countries(1991)vol 1650.

Kirsten Ewers Anderson "LCG Case studies in Chin and Shan states on codification of customary agricultural communal tenure" (Myanmar National Dialogue on Community Tenure, Myanmar, 13 January 2015).

Tom Kramer, Ernestien Jensemae r, Martin Jelsma, Tom Blickman and Transnational Institute Bouncing Back Relapse in the golden triangle(Transnational Institute).

Tom Kramer and Kevin Woods Financing Dispossession - China's Opium Substitution Programme in Northern Burma(Transnational Institute, 2012).

Land Core Group of the Food Security Working Group 13 Case Studies of Land Confiscations in Three Townships of Central Myanmar(Food Security Working Group, 2012).

Livelihoods and Food Security Trust Fund (LIFT) Household Survey 2013.

Anna Locke Property rights and development briefing: Property rights and economic growth(Overseas Development Institute, 2013).

Sandar Lwin “"Ancestral' lands to be protected under draft policy” The Myanmar Times (Myanmar, 5 December 2014) <http://www.mmtimes.com/index.php/nationalnews/12440-ancestral-lands-to-be-protected-under-draft-policy.html $>$.

Duncan Macqueen Advancing forest-farm producer groups in Myanmar within market-led community forestry: Report of an advisory mission(IIED, 2013).

Ruth S Meinzen-Dick and Rajendra Pradhan Legal pluralism and dynamic property rights(CAPRi, 2002).

Robert B Oberndorf Legal Review of Recently Enacted Farmland Law and Vacant, Fallow and Virgin Lands Management Law: Improving the Legal \& Policy Frameworks Relating to Land Management in Myanmar(Food Security Working Group's Land Core Group, 2012).

OXFAM Delivering Prosperity in Myanmar's Dryzone(OXFAM, 2014).

Nancy Lee Peluso, Alice B Kelly and Kevin Woods "Context in Land Matters: Access Effects and History in Land Formalization" (paper presented to Commoners and the Changing Commons: Livelihoods, Environmental Security, and Shared Knowledge, the Fourteenth Biennial Conference of the International Association for the Study of the Commons, Mt Fuji, Japan, 2013).

Roy Prosterman, Laura Eshbach and Darryl Vhugen Commentary on the Draft National Land Use Policy (Full Version)(Landesa, 2014). 
Giacomo Rambaldi and CJ Tarr "Participatory 3-D Modelling: Bridging the GAP between Communities and GIS Technology" in international workshop" Participatory Technology Development and Local knowledge for sustainable Land use in Southeast Asia". Chiang Mai, Thailand (2001).

RECOFTC - The Center for People and Forests Community forestry adaptation roadmap to 2020 for Cambodia(2014).

Robert Burton Oberndorf "Understanding How the Legal Framework in Myanmar Currently Supports Recognition of Communal Tenure" (National Dialogue on Customary Communal Land Tenure, Nay Pyi Taw, Myanmar, 14 February 2015).

Yukari Sekine "Globalization and local land governance: Mechanisms of confiscation and contentious politics in Myanmar's Dawei Special Economic zone area" (paper presented to Environmental Governance and Development Policy in Southeast Asia, Tokyo, Japan, 10 January 2015).

U San Thein Study on the Evolution of the Farming Systems and Livelihoods Dynamics in Northern Chin State(GRET, 2012).

The Land Core Group of the Food Security Working Group The Role of Land Tenure Security for Smallholder Farmers in National Development: a policy discussion by the Land Core Group of the Food Security Working Group.

Kyaw Tint, Oliver Springate-Baginski and Ko Ko Gyi Mehm Community Forestry in Myanmar: Progress \& Potentials(ECCDI, 2011).

TNI Myanmar Programme and TNI Agrarian Justice Programme Pro-business or propoor? Making sense of the recently unveiled draft National Land Use Policy(Transnational Institute, 2014).

Transnational Institute “Access Denied” [2013] Burma Policy Briefing no 11.

Transnational Institute The Challenge of Democratic and Inclusive Land Policymaking in Myanmar: A response to the draft National Land Use Policy(Transnational Institute, 2015).

UN Habitat and UNHCR Guidance Note on Land Issues - Myanmar(UN Habitat and UNHCR, 2010).

United States Agency for International Development USAID Country Profile, Property Rights and Resource Governance: Burma(USAID, 2013).

UNODC Southeast Asia Opium Survey 2014: Lao PDR, Myanmar(UNODC Regional Office for Southeast Asia and the Pacific, 2014).

UN-REDD Programme Guidelines on Free, Prior andInformed Consent(2013). 
Jeff Vize and Manfred Hornung "Indigenous Peoples and Land Titling in Cambodia: A study of six villages" (paper presented to Annual World Bank Conference on Land and Poverty, Washington DC).

San Win Investigation on shifting cultivation practices conducted by the hill tribes for the development of suitable agroforestry techniques in Myanmar(Forest Department, 2004).

Su Phyo Win "Rubber producers optimistic about future despite price freefall" The Myanmar Times (Myanmar, 15 December 2014) $<$ http://www.mmtimes.com/index.php/business/12546-rubber-producers-optimisticabout-future-despite-price-freefall.html $>$.

Kevin Woods "Community Forestry in Cease-Fire Zones in Kachin State, Northern Burma: Formalizing Collective Property in Contested Ethnic Areas" (paper presented to CAPRi Workshop on Collective Action, Property Rights, and Conflict in Natural Resources Management, Siem Reap, Cambodia, 2010).

Kevin Woods Baseline Study 4, Myanmar: Overview of Forest Law Enforcement, Governance and Trade(Forest Trends, 2011).

Y Yasmi, L Kelley and T Enters "Governing the Commons in Asia: Contested Tenure and Conflict over Land and Forests" in Sustaining Commons: Sustaining Our Future (paper presented to 13 th Biennial Conference of the International Association for the Study of the Commons, Hyderabad, India).

"Civic organisations urge govt, ethnic armed groups not to sell land in conflict zones" Eleven (Myanmar, $\quad 9 \quad$ February <http://www.elevenmyanmar.com/index.php?option=com_content\&view=article\&id=89 79:civic-organisations-urge-govt-ethnic-armed-groups-not-to-sell-land-in-conflictzones\&catid=44: national \&Itemid=384> . 